Інститут психології імені Г. С. Костюка

Національної академії педагогічних наук України

Український науково-методичний центр практичної психології і соціальної роботи Національної академії педагогічних наук України Державна установа «Інститут охорони здоров'я дітей та підлітків

Національної академії медичних наук України»

Державна установа «Інститут неврології, психіатрії та наркології

Національної академії медичних наук України»

Харківський національний університет внутрішніх справ

Школа соціальної роботи Університету Вейна

\title{
Українське лонгітюдне дослідження Ukrainian Longitudinal Study (ULS)
}

\author{
Методичні рекомендації
}

з використання психодіагностичних інструментів другої хвилі дослідження

https://doi.org/10.32631/uls2021

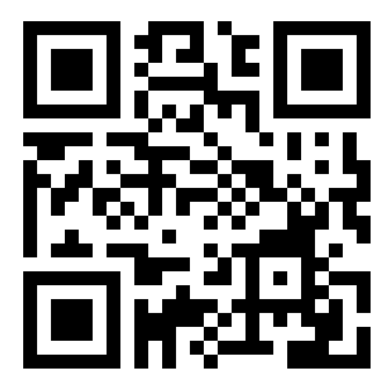

Київ - Харків

Інститут психології імені Г. С. Костюка НАПН України 
Рекомендовано до друку та подальшого практичного в закладівах освіти засіданням Вченої ради Інституту психології імені Г. С. Костюка Національної академії педагогічних наук України (протокол №10 від 30 серпня 2021 р.)

\section{Колектив авторів:}

Максименко С. Д. - дійсний член НАПН України, доктор психологічних наук, професор, директор Інституту психології імені Г. С. Костюка Національної академії педагогічних наук України;

Кокун О. М. - член-кореспондент НАПН України, доктор психологічних наук, професор, заступник директора Інституту психології імені Г.С. Костюка Національної академії педагогічних наук України 3 науково-інноваційної роботи;

Панок В. Г. - член-кореспондент НАПН України, доктор психологічних наук, професор, директор Українського науково-методичного центру практичної психології і соціальної роботи НАПН України;

Даниленко Г. М. - доктор медичних наук, професор, директор Державної установи «Інститут охорони здоров'я дітей та підлітків Національної академії медичних наук України»;

Лінський І. В. - доктор медичних наук, професор, директор Державної установи «Інститут неврології, психіатрії та наркології Національної академії медичних наук України»;

Сердюк О. О. - кандидат соціологічних наук, доцент, заступник завідувача науково-дослідної лабораторії з проблем протидії злочинності Харківського національного університету внутрішніх справ;

Бурлака В. В. - доктор філософії з соціальної роботи та психології, Школа соціальної роботи Університету Вейна, Сполучені Штати Америки;

Щербакова О. О. - доктор психологічних наук, старший науковий співробітник відділу гігієни дітей шкільного віку та підлітків Державної установи «Інститут охорони здоров'я дітей та підлітків Національної академії медичних наук України»;

Лунченко Н. В. - науковий співробітник Українського науково-методичного центру практичної психології і соціальної роботи НАПН України.

\section{Рецензенти:}

Чепелєва Н. В. - заступник директора 3 науково-дослідної роботи Інституту психології імені Г. С. Костюка Національної академії педагогічних наук України, дійсний член НАПН України, доктор психологічних наук, професор;

Бондаренко О. Ф. - завідувач кафедри психології і туризму Київського національного лінгвістичного університету, дійсний член НАПН України, доктор психологічних наук, професор.

(C) Колектив авторів, 2021

(C) Інститут психології імені Г. С. Костюка НАПН України, 2021

(C) УНМЦ практичної психології і соціальної роботи НАПН України, 2021

(C) ДУ «Інститут охорони здоров'я дітей та підлітків НАМН України», 2021

(C) ДУ «Інститут неврології, психіатрії та наркології НАМН України», 2021

(C) Харківський національний університет внутрішніх справ, 2021

(C) Університет Вейна, 2021 


\section{MICT}

Методологія дослідження

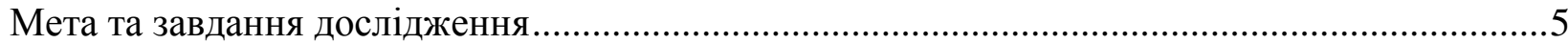

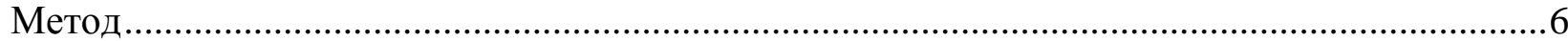

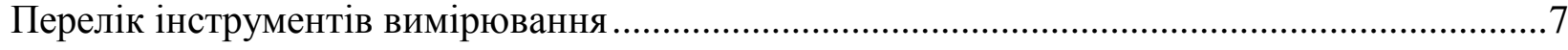

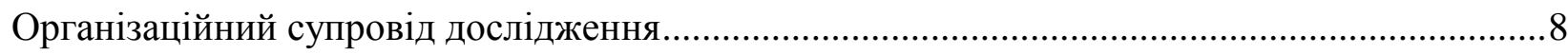

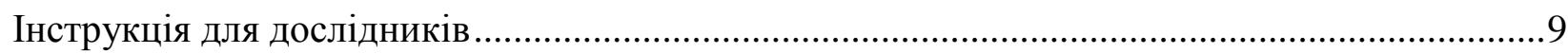

Зразок звернення до батьків учнів, які беруть участь в дослідженні...................................11

Зразок звернення до учнів, які беруть участь в дослідженні ............................................11

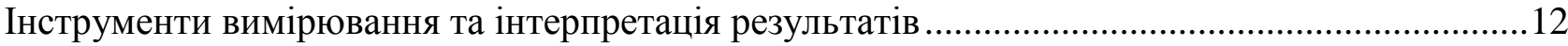

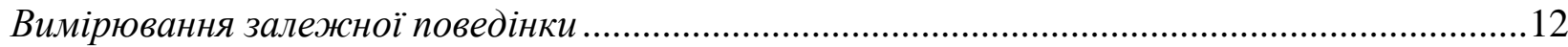

NIAAA - Короткий скринінг вживання тютюну, алкоголю та наркотиків для молоді ........12

CRAFFT - Скринінг на поведінкові розлади внаслідок вживання алкоголю та наркотиків

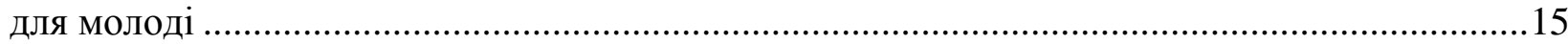

AUDIT-C - скорочений варіант опитувальника АУ ДИТ .................................................16

ASSIST - Опитувальник ВО3 для скринінгу на проблеми з алкоголем, тютюном та

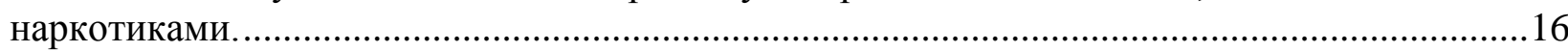

Вимірювання залежної поведінки в наступних хвилях та додаткових модулях (у дітей):..18

DDHF - Форма історії споживання алкоголю та наркотиків для дітей ....

BSTAD - Короткий інструмент скринінгу споживання тютюну, алкоголю та наркотиків для підлітків

TAPS - Інструмент вимірювання споживання тютюну, алкоголю, ліків та інших речовин 19

RAPI -Індекс алкогольних проблем Рутгера.......................................................................19

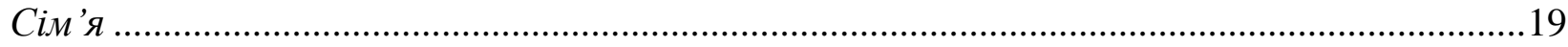

APQ - Сімейний Алабамський опитувальник................................................................ 19

АСЕ - Опитувальник шкідливого досвіду дитинства ......................................................20

Вимірювання сімейної згуртованості в наступних хвилях та додаткових модулях (у дітей

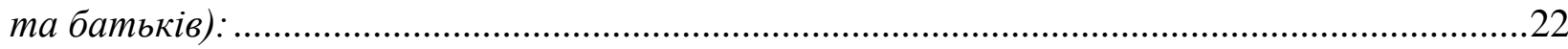

FACES-IV - Шкала сімейної гнучкості та згуртованості ................................................22

Комплексний діагностичний інструмент ASEBA ….....................................................22

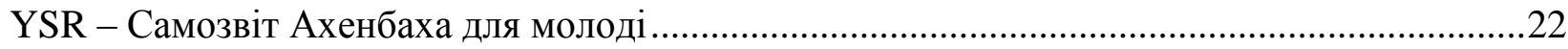

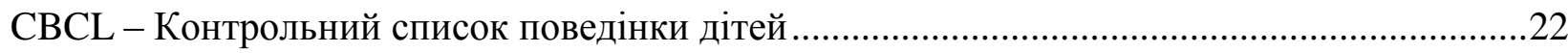

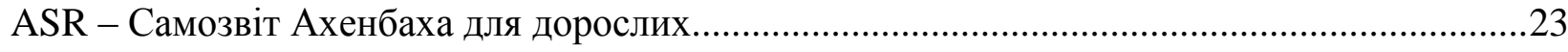

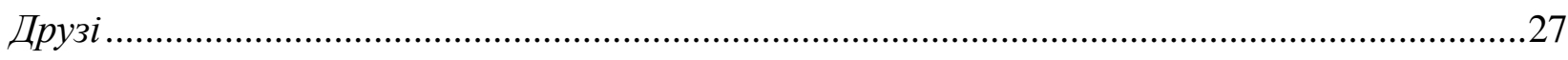

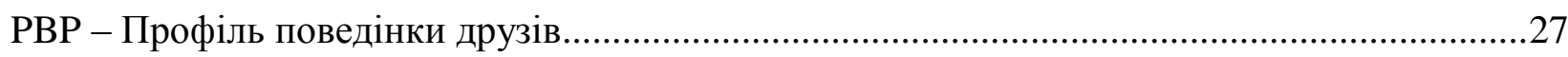

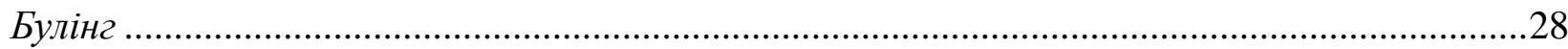

IBS - Іллінойська Шкала Булінгу: шкільний варіант .....................................................28

Суїиидальність, самотність, тривожність та депресія ...................................................29

ACSS-FAD - Шкала набутої здатності до самогубства та відсутності побоювання смерті.29

NSDUH - прямі запитання щодо суїцидальних проявів Національного опитування 3 вживання наркотиків та здоров'я 
UCLA Loneliness Scale - Шкала самотності та соціальної ізоляції.

PHQ-4 - Опитувальник здоров'я пацієнта (4 запитання для виявлення депресії та тривожності) 32

Сон .33

PSQ - Піттсбурзький Індекс Якості Сну.... .33

Загальне здоров'я. .35

GSE - Шкала загальної самоефективності ..... .35

AHP-SF - Шкала оцінювання поведінки з підтримки здоров’я (скорочений варіант для підлітків) .36

Food Security Scale - Шкала безпечності харчування (українська версія) .37

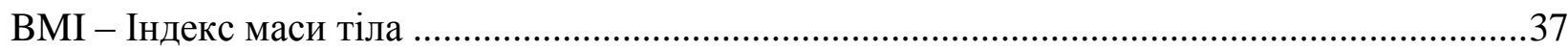

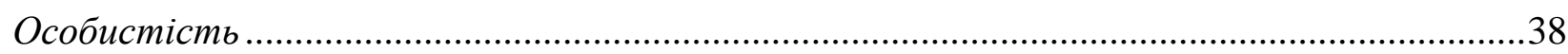

BFI-10 - П'ятифакторний опитувальник особистості «Велика П'ятірка» ............................38

Діагностика ПТСР (посттравматичного стресового розладу): ........................................40

LEC - Контрольний список травматичних подій життя …..................................................40

PCL-C - Контрольний список симптомів Посттравматичного стресового розладу ..............40

Додаток 1. Інформована згода/дозвіл батьків на участь в дослідженні.................................44

Додаток 2. Інформована згода дитини на участь в дослідженні .........................................46

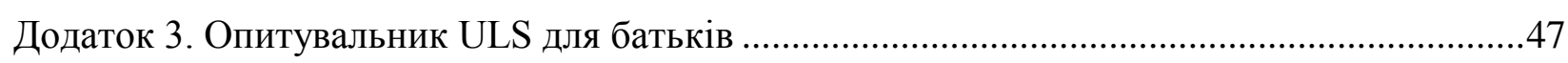

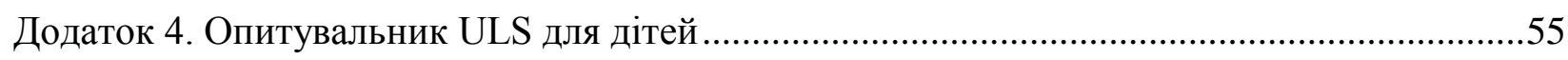

Додаток 5. Рекомендація інструментарію ULS до практичного використання в закладах освіти

Додаток 6. Лист УНМЦ практичної психології і соціальної роботи від 12.05.2021 № 45 ...69

Додаток 7. Перелік нормативно-правових документів з питань запобігання та профілактики негативних форм поведінки серед дітей та молоді

Веб-сторінка дослідження: https://intellectfound.org/uk/project/uls Сторінка містить опис дослідження, інструкцію для дослідників, офічійні листи, зразки документів, методичні рекомендації, відео записи інструктивних вебінарів психологічної служби для дослідників та додаткові матеріали для завантаження

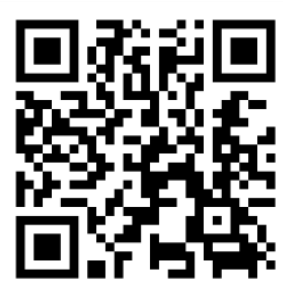




\section{Методологія дослідження}

\section{Мета та завдання дослідження}

Дослідження здоров’я дітей протягом життя «Українське лонгітюдне дослідження» Ukrainian Longitudinal Study (надалі ULS) - це моніторинг впливу різних факторів на психічне та фізичне здоров'я українських дітей протягом життя (у базовому модулі дослідження, починаючи із 6 класу) з особливим фокусом на ризикованій поведінці щодо власного здоров'я (насамперед факторах ризику залежної поведінки).

Дослідження ULS було розпочато в рамках українсько-американського проекту 3 розвитку інфраструктури наукових досліджень залежності в Україні «Сараcity Building for Lifespan Focused Substance Use Disorder Research in Ukraine» (4D43TW009310-05) під керівництвом Центру Залежностей Мічиганського Університету (США) за підтримки Міжнародного Центру Фогарті (FIC), Національного інституту здоров'я (NIH), Національного інституту алкогольної залежності та алкоголізму (NIAAA), Національного інституту наркотичної залежності (NIDA). Наукові керівники: Роберт Зукер та Морін Волтон.

\section{Дослідницький консорціум ULS:}

На теперішній час науково-дослідна робота Українське Лонгітюдне Дослідження виконується в рамках багатосторонніх договорів про співпрацю міжнародним дослідницьким консорціумом, до якого входять:

- Інститут психології імені Г. С. Костюка Національної академії педагогічних наук України, директор інституту, дійсний член НАПН України, керівники - дійсний член НАПН України, доктор психологічних наук, професор, директор Інституту психології імені Г. С. Костюка Національної академії педагогічних наук України Максименко Сергій Дмитрович; член-кореспондент НАПН України, доктор психологічних наук, професор, заступник директора Інституту психології імені Г.С. Костюка Національної академії педагогічних наук України 3 науковоінноваційної роботи Кокун Олег Матвійович;

- У Український науково-методичний центр практичної психології і соціальної роботи НАПН України (психологічна служба), керівник - член-кореспондент НАПН України, директор центру доктор психологічних наук, професор Панок Віталій Григорович;

- Державна установа «Інститут охорони здоров'я дітей та підлітків Національної Академії медичних наук України», керівник - директор інституту доктор медичних наук, професор Даниленко Георгій Миколайович;

- Державна установа «Інститут неврології, психіатрії та наркології Національної академії медичних наук України», керівник - директор інституту доктор медичних наук, професор Лінський Ігор Володимирович;

- Харківський національний університет внутрішніх справ, керівник - заступник завідувача науково-дослідної лабораторії з проблем протидії злочинності кандидат соціологічних, доцент Сердюк Олексій Олександрович;

- Школа соціальної роботи Університету Вейна (США), керівник - доктор філософії з соціальної роботи та психології Бурлака Віктор Володимирович.

- Центр залежностей Мічиганського університету (США), наукові консультанти директори центру Роберт Зукер та Морін Волтон.

Зразок, за яким ми побудували наше дослідження, - це Мічиганське лонгітюдне дослідження (MLS), яке триває 33 роки. Його автори з Центру залежностей Мічиганського університету схвалили методику ULS та допомагають у проведенні опитування і публікації його результатів у найкращих світових журналах, що входять до світових наукометричних баз Scopus та Web of Science.

Метою дослідження с вивчення змін поведінки та здоров'я однієї і тієї ж людини протягом тривалого періоду часу з особливою увагою на шкідливих формах поведінки зловживання алкоголем, наркотиками, девіантній поведінці тощо (починаючи 3 шостого класу, 11-12 років) з використанням міждисциплінарної методології. 


\section{Завдання дослідження:}

- ідентифікувати осіб, які мають ризик поведінкових розладів та розладів, пов'язаних із вживанням і зловживанням наркотичними речовинами до моменту закінчення школи;

- визначити, які конкретні показники в дитинстві можуть свідчити про зростання ймовірністі того, що у дорослому віці буде діагностовано поведінковий розлад (розлад залежності від хімічних речовин);

- визначити вплив близького соціального оточення на проблеми зловживання хімічними речовинами серед підлітків.

Основною гіпотезою дослідження $€$ різноманітність факторів (мікро- та макросоціальних, вплив однолітків, вплив сім'ї, генетичних та факторів навколишнього середовища), які сприяють виникненню психічних та поведінкових розладів, розладів залежності та інших поведінкових проблем у дітей, а також зв'язок їх проблемної поведінки 3 психічними та поведінковими розладами членів родини (розладами залежності).

Також ми плануємо визначити вплив війни на сході України як фактор ризику виникнення психічних та поведінкових розладів у довгостроковій перспективі.

Проблемна ситуація у методологічному вимірі - це актуальна потреба впровадження міждисциплінарних дослідницьких підходів до вивчення зловживання наркотичними речовинами в Україні та застосування лонгітюдної методології з метою інтеграції у світовий науковий простір.

Дослідження ULS має модульну структуру - це означає, що окрім основного базового модуля (діти 11-12 років), у лонгітюдному форматі ми вивчаємо зміни поведінки інших груп. Кількість додаткових модулів необмежена, їх можливо долучати до ULS зберігаюси систему кодування та основні методичні підходи. На теперішній час виконується 2 додаткових модуля ULS+:

- «студентський» модуль ULS+ реалізується в рамках кросс-секційного моніторингу залежної поведінки серед молоді «Молодь та наркотики», який триває вже 25 років, об'єктом є молодь у віці 17-25 років, яка навчається у 3ВО міста Харків.

- «клінічний» модуль ULS+ реалізується на базі Державної установи «Інститут охорони здоров'я дітей та підлітків Національної Академії медичних наук України», об’єктом є пацієнти ІОЗДП з психічними та соматичними розладами різного генезу та їх батьки.

\section{Метод}

Методика: в основі інструментарію ULS лежать найбільш цитовані у світовій науці багатовимірні методики аналізу поведінки дитини: ми задаємо одні й ті ж запитання дитині та їі батькам (або особам, які їх замінюють), що дозволяє порівняти їх відповіді і побудувати об'єктивну картину того, що відбувається в родині та зі здоров'ям дитини. Також використано діагностичні та скринінгові інструменти щодо вивчення сімейної ситуації, проявів булінгу, залежної та суїцидальної поведінки, психічного та фізичного здоров'я тощо. Висновок щодо інструментарію та його рекомендацію до практичного використання в закладах освіти отримано від Інституту психології імені Г. С. Костюка.

Процедура: ULS - це лонгітюдне дослідження, тобто кожного року ми опитуємо одних і тих же дітей та їх батьків (або осіб, які їх замінюють) і продовжуватимемо це якомога довше $(5,10,15$ років, стільки, скільки зможемо підтримувати з ними контакт). Формат проведення з 2019 року - електронне опитування. Пілотне дослідження першої хвилі здійснювалось віч-на-віч з використанням паперових опитувальників, процедура виявилась дуже ресурсомісткою i була замінена на веб-опитування, що дозволяє досягнути необмеженої кількості учасників.

Веб-опитувальник заповнюється двома цільовими групами респондентів:

- діти 11-12 років (6 клас), тривалість інтерв'ю 90 хв. (2 урока 3 перервою, інтерв'ю, що проводиться в невеликих групах в комп'ютерному класі у присутності дослідника); 
- батьки дітей (по два для однієї дитини або по одному для однієї дитини, якщо це неповна сім'я), тривалість 45 хв. Опитувальник заповнюється самостійно, під час батьківських зборів або вдома у вільний час. Tym $\boldsymbol{i}$ надалi nid понятmям «батьки» ми розумісмо як біологічних батьків, так і осіб, щцо ӥх замінюють.

Конфіденційність - опитування не анонімне, але вся персональна інформація, яку повідомлюють учасники, повністю конфіденційна. Перед заповненням опитувальника усі учасники підписують інформовану згоду, в якій повідомляють власні персональні дані для забезпечення можливості звернутись до них повторно. До повідомлених персональних даних буде доступ тільки у відповідального виконавця виключно з метою забезпечення кодування. Дані, які учасники повідомлюють в опитувальнику, зберігатимуться окремо від інформованої згоди - це означає, що вони будуть анонімні. До відповідей учасників дослідження не буде доступу у викладачів, персоналу школи та інших осіб, що можуть їх знати. Відповіді не будуть аналізуватись індивідуально - дані будуть використані тільки після комп'ютерної обробки в узагальненому вигляді. У разі невиконання своїх обов'язків, виконавці дослідження несуть відповідальність згідно чинного законодавства, а саме ст. 16 Закону України «Про захист персональних даних».

Одиниця спостереження - це сім'я, дитина і її батьки.

Періодичність збору даних - щорічно до досягнення дитиною 18 років, потім інтервал 3-5 років між хвилями.

Географічне покриття - дослідження розпочато на всій території України 3 особливим акцентом на чотири регіони: Схід, Південь, Центр і Захід.

\section{Перелік інструментів вимірювання}

1) Для дітей:

Вимірювання залежної поведінки у першій хвилі:

- NIAAA brief youth screening guide - Короткий скринінг вживання алкоголю та наркотиків для молоді.

- CRAFFT - Скринінг на поведінкові розлади внаслідок вживання алкоголю та наркотиків для молоді.

Багатовимірні опитувальники:

- Alabama Parenting Questionnaire (APQ) - Сімейний Алабамський опитувальник.

- The Achenbach Youth Self Report (YSR) - Самозвіт Ахенбаха для молоді.

Фонові показники:

- Peer Behavior Profile (PBP) - Профіль поведінки друзів.

- $\quad$ Illinoi Bully Scale (IBS) - Іллінойська шкала булінгу.

- Acquired Capability for Suicide Scale - Fearlessness About Death (ACSS-FAD) - Шкала набутої здатності до самогубства та відсутності побоювання смерті (ACSS-FAD).

- $\quad$ The UCLA Three-Item Loneliness Scale - Шкала самотності та соціальної ізоляції.

- PHQ-4 - скринінг тривожності та депресії.

- The General Self-Efficacy scale (GSE) - Шкала загальної самоефективності.

- The Pittsburgh Sleep Quality Index (PSQ) - Піттсбурзька шкала якості сну.

- $\quad$ Short Form Adolescent Health Promotion scale (HPS) - Скорочений варіант для підлітків Шкали оцінювання поведінки з підтримки здоров'я.

- BFI-10 - Скорочений варіант п’ятифакторного опитувальника особистості «Велика П'ятірка» (10 запитань).

- Food Security Scale - Шкала безпечності харчування (українська модифікована версія).

- $\quad$ BMI (body mass index) - Індекс маси тіла (відношення зросту до ваги).

2) Для батьків:

Вимірювання залежної поведінки:

- AUDIT-C - The Alcohol Use Disorders Identification Test - Consumption. Скорочений варіант опитувальника АУДИТ

Багатовимірні опитувальники: 
- Achenbach Adult Self-Report (ASR) - Самозвіт Ахенбаха для дорослих.

- Achenbach Child Behavior Check List (CBCL) - Список Ахенбаха для перевірки проблем дитини.

- Alabama Parenting Questionnaire (APQ) - Сімейний Алабамський опитувальник.

Фонові показники:

- BMI (body mass index) - Індекс маси тіла (співвідношення зросту і ваги).

Методики першої хвилі, які не використовуються у другій хвилі ULS, але присутні у додаткових модулях ULS+:

- Adverse Childhood Experiences (ACEs) Questionnaire - Опитувальник шкідливого досвіду дитинства.

- BFI-10 - Скорочений варіант п’ятифакторного опитувальника особистості «Велика П'ятірка» (10 запитань).

- Alcohol, Smoking, and Substance Involvement Screening Test (ASSIST) - Опитувальник BO3 для скринінгу на проблеми з алкоголем, тютюном та наркотиками.

- Діагностика ПТСР (посттравматичного стресового розладу):

- TLEC - Список травматичних подій (модифікований, додано 3 додаткових типи подій, пов'язаних з військовими діями).

- $\quad$ PCL-C (Список симптомів Посттравматичного стресового розладу - цивільна версія).

Вимірювання залежної поведінки у дітей в наступних хвилях дослідження:

- Drinking and Drug History Form for Children/Youth - Форма історії споживання алкоголю та наркотиків.

- BSTAD - Brief Screening Instrument for Adolescent Tobacco, Alcohol, and Drug Use Короткий інструмент скринінгу споживання тютюну, алкоголю та наркотиків для підлітків.

- TAPS - The Tobacco, Alcohol, Prescription medication, and other Substance use tool Інструмент вимірювання споживання тютюну, алкоголю, ліків та інших речовин.

- AUDIT-C - Скорочений варіант опитувальника АУДИТ.

- RAPI - Rutgers Alcohol Problem Index - Індекс алкогольних проблем Рутгера.

Вимірювання сімейної згуртованості в наступних хвилях дослідження (у дітей та батьків):

- FACES-IV - Шкала сімейної гнучкості та згуртованості.

Організаційний супровід дослідження

Інструментарій Українського лонгітюдного дослідження рекомендований до практичного використання в закладах освіти засіданням Вченої ради Інституту психології імені Г. С. Костюка НАПН України (протокол №10 від 30 серпня 2021 р.) (Додаток 5).

Дослідження здійснюється відповідно до пріоритетних напрямів роботи психологічної служби у системі освіти у 2021/2022 навчальному році затверджених Листом МОН від 16.07.2021 № 1/9-363 «Про пріоритетні напрями роботи психологічної служби у системі освіти у 2021/2022 н. р.» (інформація про дослідження на ст. 15), відповідно до Листа УНМЦ практичної психології і соціальної роботи НАПН України від 12.05.2021 № 45 (Додаток 6), надісланого директорам/завідувачам обласних навчально-методичних центрів/кабінетів психологічної служби, в рамках інших нормативно-правових документів 3 питань запобігання та профілактики негативних форм поведінки серед дітей та молоді (Додаток 7), згідно з Інструкцією наведеною далі.

Практичні психологи та соціальні педагоги, які бажають взяти участь в Украӥнському лонгітюдному дослідженні, мають погодити це з керівником ЗЗСО та включити це дослідження до власного плану роботи на наступний навчальний рік.

Керівники 33СО, за бажанням, матимуть можливість укласти договір про співпрацю 3 дослідницьким консорціумом.

Офіційні листи, зразки документів, відео записи інструктивних вебінарів психологічної служби для дослідників та усі супутні матеріали можливо переглянути та завантажити за посиланням: https://intellectfound.org/uk/project/uls 


\section{Інструкція для дослідників}

\section{Порядок проведення дослідження:}

1. Провести нумерацію (кодування) учасників, заповнивши відповідну таблицю.

2. Розіслати батькам повідомлення з посиланням на опитувальник та номером учасника.

3. Провести опитування учнів у комп’ютерному класі або за власними приладами.

\section{1. Нумерація (кодування) учасників.}

Номер (код) учасника складається 314 цифр, його потрібно буде вводити учаснику дослідження при заповненні електронного опитувальника.

Дослідник, який безпосередньо проводитиме опитування власноруч нумерус всіх дітей за списком та вносить їхні дані в таблицю за такою схемою (див. зразок у табл. 1):

- $\quad$ перші 3 цифри - останні дві цифри номера календарного року та номер півріччя, у якому розпочато участь у дослідженні, тобто присвоєно номер учаснику (наприклад, 2021 рік 1 півріччя календарного року = 211 або осінь 2021 року - це друге півріччя календарного року $=212$ );

- наступні 5 цифр - поштовий індекс закладу загальної середньої освіти (33СО), де проводиться опитування (наприклад, 61001);

- наступні 3 цифри - номер 33СО, де проводиться опитування (наприклад, школа номер один $=001$, ліцей номер двадцять три $=023$, гімназія номер сто сім $=107$; якщо у населеному пункті є тільки один 33СО, який не має номеру, а має тільки назву - слід позначати його 001, якщо таких закладів два - слід зв'язатись 3 дослідником і визначитись який з цих закладів буде пронумерований 001, а який 002;

- $\quad$ наступні 3 цифри - порядковий номер учасника (наприклад, учасник номер один = 001, учасник номер двадцять три $=023$, учасник номер сто сім $=107)$.

Номер (код) учасника однаковий для дитини та іï батьків (одиницею спостереження в дослідженні $\epsilon$ сім'я, вивчається розвиток дитини). Номер учасника $\epsilon$ незмінним протягом всього дослідження. Розрізнення учасників 3 однієї одиниці спостереження (родини) здійснюється завдяки додатковій нумерації, яка здійснюється при введенні даних у комп'ютер відповідальним виконавцем. У випадку, коли у групі спостереження (класі) навчається 2 (або більше) дитини від одних батьків - кожній дитині присвоюється свій власний номер (код), а батьки надають дозвіл і заповнюють опитувальники на кожну дитину окремо, кожен зі своїм власним номером (кодом). Номери (коди) учасників та їхні ПІБ заносяться в таблицю, яка зберігатиметься у відповідальної особи, яка проводить опитування (дослідник).

Таблиця 1

Зразок таблиці учасників «Українського Лонгітюдного Дослідження» 33СО (вказати назву)

\begin{tabular}{|c|c|c|c|c|c|c|c|c|c|c|c|c|}
\hline \multicolumn{4}{|c|}{ Номер (код) учасника } & \multirow[b]{2}{*}{ 胥 } & \multirow[b]{2}{*}{ 芯 } & \multicolumn{4}{|c|}{ ПІБ учасників } & \multirow[b]{2}{*}{ 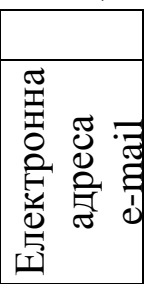 } & \multirow[b]{2}{*}{ 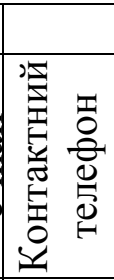 } & \multirow[b]{2}{*}{ 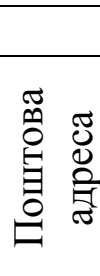 } \\
\hline 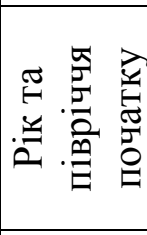 & 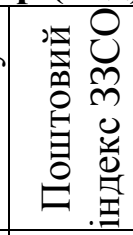 & $\begin{array}{ll}0 & 0 \\
0 & 0 \\
0 & 0 \\
0 & m \\
0 & m\end{array}$ & 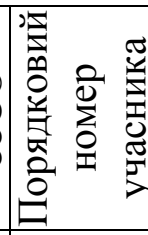 & & & 萠 & $\stackrel{\vec{J}}{\Sigma}$ & 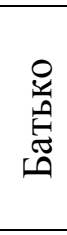 & 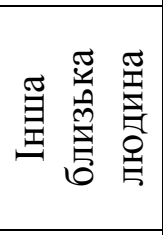 & & & \\
\hline 211 & 61001 & 169 & 001 & & & & & & & & & \\
\hline 211 & 61001 & 169 & 002 & & & & & & & & & \\
\hline 211 & 61001 & 169 & 002 & & & & & & & & & \\
\hline 211 & 61001 & 169 & 004 & & & & & & & & & \\
\hline 211 & 61001 & 169 & 005 & & & & & & & & & \\
\hline
\end{tabular}

Після надання батьками згоди на участь їх та/або їхньої дитини в дослідженні дослідник надсилас таблицю учасників у електронній формі відповідальному виконавцю.

Назва файлу 3 таблицею: назва файлу складається 3 перших 11 цифр номерів учасників (рік та півріччя початку, поштовий індекс та номер 33СО), наприклад, 21161001169.doc 
Дані дослідження надсилаються досліднику за окремим запитом електронною поштою відповідно до надісланої ним раніше таблиці учасників.

\section{2. Процедура опитування батьків}

У випадку, коли батьки згодні взяти участь у дослідженні вони за необхідності, якщо не надали іiі раніше, підписують інформовану згоду (зразки можливо завантажити за посиланням, наведеним нижче) та зазначають на обох примірниках номер (код) учасника, який їм повідомляс дослідник, грунтуючись на заздалегідь внесених у таблицю даних.

Батькам надається посилання на електронний опитувальник з проханням заповнити його самостійно у вільний час. Посилання з номером (кодом) учасника доцільно розіслати батькам в електронному вигляді, щоб вони лише натиснули на нього для потрапляння до опитувальника, за допомогою електронної пошти, месенджерів (Viber, Wattsapp, Telegram), соціальних мереж (Facebook) тощо.

Для заповнення електронного опитувальника на комп’ютері, планшеті або смартфоні батькам потрібно перейти за надісланим посиланням або зісканувати QR-код:

\section{http://survey.intellectfound.org/index.php/627767}

Дослідник фіксує увагу батьків на тому, що їхні відповіді зберігаються у знеособленому масиві даних на віддаленому сервері і ніхто, крім відповідального виконавця, не матиме до них доступу.

\section{3. Процедура опитування дітей}

Опитування дитини проводиться незалежно від того, чи взяли участь у дослідженні ії батьки.

Опитування дітей має проходити у комп'ютерному класі. Комп’ютери мають бути приєднані до мережі інтернет. Кожна дитина повинна сидіти за окремим пристроєм i відповідати на запитання індивідуально (можливо використання власного пристрою).

У випадку, коли дитина навчається вдома (або тимчасово знаходиться вдома), вона може пройти опитування на власному електронному пристрої (комп'ютері, планшеті, смартфоні). У такому випадку дослідник надсилає кожній дитині особисто посилання на опитувальник і номер (код) учасника, який їй буде потрібно внести в опитувальник, та контролює процес заповнення дистанційно. Дослідник фіксує увагу дітей на тому, що їхні відповіді зберігаються у знеособленому масиві даних і ніхто з відомих їм осіб не матиме до них доступу.

Для заповнення електронного опитувальника на комп’ютері, планшеті або смартфоні дітям потрібно перейти за посиланням або зісканувати QR-код:

\section{http://survey.intellectfound.org/index.php/225223}

Дослідник заздалегідь відкривас на комп'ютері відповідну сторінку 3 опитувальником у браузері і повідомляс кожній дитині її номер (код) учасника. При заповненні опитувальника вдома дитині буде потрібно ввести номер (код) учасника, який дослідник заздалегідь вніс у таблицю учасників та надіслав дитині з посиланням.

\section{4. Зберігання таблиці учасників (та інформованих згод, за наявності)}

Інформовані згоди/дозволи, підписані батьками зберігаються в дослідника в 33СО. Таблиця зберігається в паперовій та електронній формі в дослідника, який безпосередньо проводить опитування, та надсилається в електронній формі керівнику дослідження: Сердюку Олексію Олександровичу; тел. +380503271771, e-mail: serdyuk.alexey@gmail.com

Методичний комплекс з описом діагностичних методик та зразками супутніх документів можливо завантажити на веб-сторінці дослідження ULS за посиланням: https://intellectfound.org/uk/project/uls 


\section{Зразок звернення до батьків учнів, які беруть участь в дослідженні}

Шановні батьки!

Запрошуємо Вас та Вашу дитину до участі в медико-соціальній програмі 3 профілактики порушень здоров'я дітей шкільного віку. Програма започаткована Інститутом психології імені Г.С. Костюка НАПН України та Українським науково-методичним центром практичної психології і соціальної роботи спільно із дослідницьким консорціумом національних та закордонних установ.

Метою програми є спостереження за здоров'ям дітей шкільного віку та їх батьків 3 особливим фокусом на ризикованій поведінці стосовно власного здоров'я. Опитувальники покривають багато тем і включають питання про стиль життя, стан фізичного та психологічного здоров'я, різноманітний досвід, який може негативно вплинути на здоров'я Вашої дитини, а також різні відомості про її життя в родині.

Методика дослідження передбачає встановлення однакових запитань дітям та їх батькам, щоб порівняти отримані відповіді між собою. Тому нам важливо щоб Ви взяли участь в цьому опитуванні. Якщо з будь яких причин Ви не забажаєте брати участь в цьому дослідженні - Ваша дитина може взяти участь в ньому і без Вас, але тільки за Вашим дозволом.

Участь у програмі дозволить нам своєчасно визначити ризики погіршення здоров'я Вашої дитини, своєчасно на них відреагувати, i, у разі потреби, провести індивідуальні та групові профілактичні заходи, спрямовані на виявлені в ході дослідження проблеми.

Ми не зможемо повідомити Вам які саме відповіді дала Ваша дитина, але, в разі виявлення ризиків для іiі здоров'я, відреагуємо в рамках своєї компетенції. Якщо буде потрібно Ваше втручання - ми обов'язково Вам про це повідомимо.

Опитування не анонімне, але вся персональна інформація, яку Ви повідомите, повністю конфіденційна і не може бути піддана розголосу. До Ваших відповідей не буде доступу в осіб, що можуть Вас знати. Відповіді не будуть аналізуватись індивідуально - дані будуть використані тільки після комп'ютерної обробки в узагальненому вигляді за індивідуальними кодами у знеособленому масиві даних. Ми збираємо Ваші контактні дані, оскільки передбачаємо повторно звертатись до Вас у майбутньому щоб вивчити, як змінюється життя та здоров'я Вашої дитини з часом.

У ході цього дослідження Вам буде необхідно відповісти на запитання електронної анкети перейшовши за наданим Вам посиланням, це займе у Вас від 30 до 45 хвилин. На початку Вам потрібно буде ввести 14 значний код учасника. Який ми Вам надішлемо разом 3 посиланням.

Ви можете відмовитися від участі або перервати участь в опитуванні в будь-який час, якщо Вам буде некомфортно відповідати на запитання без будь-яких наслідків. Конфіденційна інформація, вже повідомлена Вами, в такому разі буде знищена.

\section{Зразок звернення до учнів, які беруть участь в дослідженні}

Шановні учні!

Ми проводимо анкетування, яке дасть можливість зрозуміти як події у Вашому житті і житті Вашої родини впливають на Вашу поведінку, самопочуття і успішність у школі.

Заповнення анкети триватиме біля години. Звертаємо Вашу увагу на тому, що Ваші відповіді матимуть конфіденційний характер, тобто ні адміністрація, ні вчителі, ні батьки не будуть знати Ваші відповіді. Тому ми, ще раз просимо щиро відповідати на запропоновані питання. Перед заповненням Вам потрібно ввести свій індивідуальний 14 значний код учасника, який я Вам надам. Якщо у вас виникнуть в процесі заповнення анкети запитання, Ви можете їх задати мені. 


\section{Інструменти вимірювання та інтерпретація результатів}

\section{Вимірювання залежної поведінки}

Для дітей:

NIAAA - Короткий скринінг вживання тютюну, алкоголю та наркотиків для молоді Запитання 9-14 в опитувальнику ULS для дітей (Додаток 4)

Цитування: NIAAA brief youth screening guide. Alcohol Screening and Brief Intervention for Youth: A Practitioner's Guide. (Практичний посібник 3 алкогольного скринінгу та короткострокового втручання серед молоді), Електронний ресурс, спосіб доступу: https://www.niaaa.nih.gov/publications/clinical-guides-and-manuals/alcohol-screening-and-briefintervention-youth

Короткий скринінг вживання тютюну, алкоголю та наркотиків для молоді базується на методиці скринінгу вживання алкоголю NIAAA Alcohol Screening and Brief Intervention for Youth: A Practitioner's Guide («Практичний посібник 3 алкогольного скринінгу та короткострокового втручання серед молоді»). Розширений українській варіант, використаний нами в опитувальнику ULS, включає запитання про наркотики, ідентичні першій частині опитувальника CRAFFT (чи $\epsilon$ у респондента друзі, що вживали алкоголь/тютюн/наркотики та чи вживав він їх сам). Запитання про друзів доповнені нами 5и позиційною шкалою з РВР - Профілю поведінки друзів (див. нижче) та доповнюють цей профіль додатковими показниками споживання адиктивних речовин.

Оригінальний опитувальник NIAAA сфокусований на ранньому виявленні серед молоді 9-18 років алкогольних проблем та їх профілактиці. Він розроблений командою дослідників Національного інституту по зловживанню алкоголем та алкоголізму (США) у співпраці з Американською академією педіатрії та практикуючими клінічними фахівцями. Він заснований на емпіричних дослідженнях предикторів алкогольної залежності. Запропоновані скринінгові запитання швидкі та універсальні і, на відміну від інших методик, включають питання про споживання алкоголю серед друзів. Скринінгові запитання можна використовувати у будь-який час, окремо або разом 3 іншими інструментами, як частину клінічного інтерв'ю, як частину письмового анкетного опитування або комп'ютерного скринінгу до зустрічі з лікарем.

Короткий скринінг вживання алкоголю для молоді сфокусований на ранньому виявленні серед молоді 9-18 років алкогольних проблем та їх профілактиці. Він розроблений командою дослідників NIAAA у співпраці з Американською академією педіатрії та клінічними фахівцями-практиками. Посібник розроблено на основі емпіричних досліджень предикторів алкогольної залежності. Запропоновані у цьому посібнику скринінгові запитання швидкі та універсальні. Варто зазначити, що, на відміну від інших методик, цей скринінг містить запитання про споживання алкоголю не тільки самими респондентами, але і серед їх друзів. Посібник видано у двох формах: у формі детального керівництва, матеріал якого викладений на 46-ти сторінках, та у компактній формі брошури, надрукованої на одному аркуші з оборотом, який складається у 5 разів, для використання під час інтерв'ю 3 підлітком (рис. 1). У посібнику щодо молоді різного віку вживається термін «пацієнт», оскільки він розрахований на використання як лікарями в умовах медичного стаціонару та амбулаторії, так і на використання іншими фахівцями в неклінічних умовах - шкільними психологами, соціальними робітниками тощо.

Скринінгові запитання можна використовувати у будь-який час, окремо або разом 3 іншими інструментами як частину клінічного інтерв'ю, як частину письмового анкетного опитування або попереднього комп'ютерного опитування до зустрічі з лікарем.

Показанням до скринінгу молоді на вживання алкоголю може бути: щорічний медичний огляд; відвідування лікаря з гострими захворюваннями; виклик швидкої медичної допомоги або одне з наведеного нище:

- якщо лікар не бачить пацієнта регулярно;

- якщо підлітки курять - вони, найімовірніше, уживають алкоголь;

- якщо наявні умови, пов'язані з підвищеним ризиком зловживання психоактивними речовинами, такі як: депресія, тривожність або поведінкові проблеми; 
- якщо $є$ проблеми зі здоров'ям, які можуть бути пов'язані з алкоголем, як-от: нещасні випадки або травми; інфекції, що передаються статевим шляхом, або небажана вагітність; зміни в їжі або сні чи безсоння; шлунково-кишкові розлади; хронічні болі;

- якщо наявні суттєві поведінкові зміни, як-от: зростаюча опозиційна поведінка; значні розлади настрою; втрата інтересу до діяльності; зміна друзів; зниження навчальної успішності; велика кількість прогулів у школі.

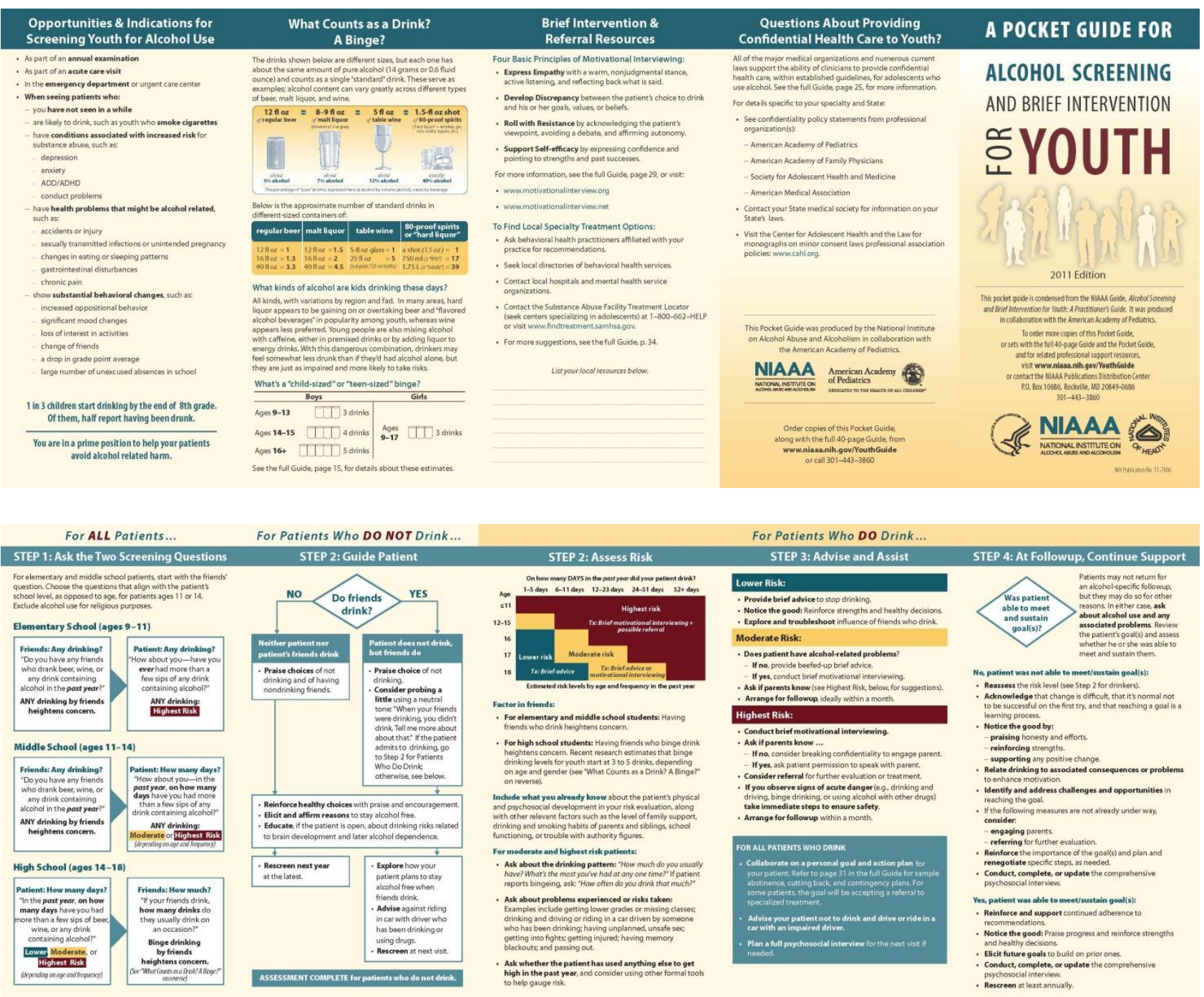

Рисунок 1. Скорочений варіант «Практичного посібника 3 скринінгу вживання алкоголю та короткострокового втручання для молоді».

Згідно 3 посібником, скринінг вживання алкоголю та відповідні короткострокові втручання мають чотири кроки.

Крок 1: Поставити два скринінгові запитання.

Одне запитання - про споживання алкоголю друзями молодої особи, друге - про частоту споживання алкоголю самою молодою особою. Для учнів початкової та середньої школи слід починати із запитання про друзів. Для пацієнтів у віці 11 або 14 років слід вибрати запитання, які відповідають шкільному рівню, а не віку. Також слід виключити вживання алкоголю як частину релігійних обрядів.

1.1. Для початкової школи (9-11 років) слід починати із запитання про друзів.

Запитання 1. (Друзі: будь-яке вживання.) «Чи є у Вас друзі, які вживали пиво, вино або будь-який напій, що містить алкоголь, минулого року?». Будь-яке вживання алкоголю друзями викликає занепокоєння як фактор обтяження.

Запитання 2. (Молода особа: будь-яке вживання.) «Як щодо Вас - чи вживали Ви колись більше, ніж кілька ковтків пива, вина чи будь-якого напою, що містить алкоголь?» Будь-яке вживання - високий ризик. 
1.2. Для середньої школи (11-14 років) слід починати із запитання про друзів.

Запитання 1. (Друзі: будь-яке вживання.) «Чи є у Вас друзі, які вживали пиво, вино або будь-який напій, що містить алкоголь, минулого року?». Будь-яке вживання алкоголю друзями викликає занепокоєння як фактор обтяження.

Запитання 2. (Молода особа: скільки днів?) «Як щодо Вас - скільки днів у минулому році Ви вживали більше, ніж кілька ковтків пива, вина або будь-якого напою, що містить алкоголь?» Будь-яке вживання - помірний або високий ризик.

1.3. Для старшої школи (14-18 років) слід починати із запитання про пацієнта.

Запитання 1. (Молода особа: скільки днів?) «Скільки днів у минулому році Ви вживали більше, ніж кілька ковтків пива, вина або будь-якого напою, що містить алкоголь?» Залежно від кількості днів - низький, помірний або високий ризик.

Запитання 2. (Друзі: скільки п’ють?) «Якщо Ваші друзі п’ють, скільки вони випивають за один раз?» Пияцтво друзів (від 3 до 5 і більше стандартних доз за один раз) викликає занепокоєння як фактор обтяження.

Крок 2: Поради (для осіб, які не п’ють) та оцінка ризику (для осіб, які п’ють).

Якщо особа НЕ П'Є - перехід до Кроку 2.1: Поради.

Тут також є дві можливі альтернативи.

1. Якщо ні молода особа, ні іiі друзі не п’ють - схвалюється і заохочується ії вибір не пити та обирати друзів, які не п'ють; виявляються і підтверджуються причини залишатись тверезим; якщо з особою відверті стосунки, йому повідомляють про ризики пиття, пов'язані 3 порушенням розвитку мозку і залежністю.

2. Якщо молода особа не п’ $\epsilon$, а ii друзі п’ють - крім схвалення і всього, що було описано вище, слід поставити запитання нейтральним тоном: «Ви казали, що коли ваші друзі пили, Ви не пили. Розкажіть про це докладніше». Якщо особа зізнається, що все ж таки пила, треба перейти до Кроку 2.2: Оцінка ризику для осіб, які пили. Якщо особа не пила, треба дізнатись, як вона планує залишитись тверезою, коли друзі п’ють. Їй також треба порадити «не їздити в машині з п’яним водієм або з водієм, який вживає наркотики».

На цьому скринінг для осіб, які не п’ють, завершено.

Якщо особа П'

Оцінювання ризику відбувається відповідно до табл. 2 за трьома ступенями - низький, помірний або високий ризик.

Таблиця 2

Оцінка рівня ризику розвитку залежності відповідно до віку та кількості днів, коли особа пила, протягом минулого року

\begin{tabular}{|c|c|c|c|c|c|}
\hline & \multicolumn{5}{|c|}{ Скільки днів за минулий рік особа пила } \\
\hline Вік & $1-5$ & $6-11$ & $12-23$ & $24-51$ & 52 та більше \\
\hline$\leq 11$ & & & & & \\
\hline $12-15$ & & & \multicolumn{2}{|c|}{ Високий ризик } & \\
\hline 16 & & \multicolumn{2}{|c|}{ Середній ризик } & & \\
\hline 17 & \multicolumn{2}{|l|}{ Низький ризик } & & \\
\hline 18 &
\end{tabular}

1. Низький ризик потребує коротких порад.

2. Середній ризик потребує коротких порад або мотиваційного інтерв'ювання.

3. Високий ризик потребує короткого мотиваційного інтерв'ювання та можливого направлення на подальшу діагностику або лікування.

Осіб із середнім та високим ризиком слід запитати про їхні алкогольні патерни та про наявність, пов'язаних $з$ уживанням алкоголю, проблем та ризиків, таких як: незахищений секс, зниження навчальної успішності, їзда на машині у стані сп'яніння, бійки та травми, втрата пам'яті. Також треба з'ясувати, чи не вживала особа будь-які інші речовини протягом останнього року, і розглянути можливість застосування інших формалізованих діагностичних інструментів. 
Крок 3: Консультація та допомога.

Низький ризик. Потрібно дати коротку пораду кинути пити. Звернути увагу на позитивні моменти - посилювати сильні і здорові рішення. Вивчити та усунути вплив друзів, які п’ють.

Середній ризик. Якщо особа не має, пов'язаних з уживанням алкоголю, проблем потрібно дати коротку пораду, а якщо такі проблеми $\epsilon-$ провести коротке мотиваційне інтерв'ювання та запитати, чи знають батьки про ії проблеми. Призначити наступну зустріч, найкраще - протягом місяця.

Високий ризик. Треба провести коротке мотиваційне інтерв'ювання. Якщо батьки не знають про проблеми молодої особи, потрібно розглянути можливість порушення конфіденційності та запрошення батьків до співпраці, а якщо батьки знають про їі проблеми, треба запитати дозволу особи на співбесіду з ними. Розглянути напрямки подальшого оцінювання або лікування, що випливають з оцінки важкості стану. Призначити наступну зустріч протягом місяця.

Для всіх осіб, які п’ють, потрібно розробити план дій щодо скорочення або припинення вживання алкоголю, дати пораду не їздити у стані сп'яніння за кермом або в машині з п'яним водієм, а також призначити поглиблене психосоціальне обстеження на наступному візиті.

Крок 4: Під час подальшого спостереження продовжувати надавати підтримку Центральне запитання: «Чи в змозі особа досягнути поставлених цілей і підтримувати ixx?»

Якщо НI, особа не в змозі досягнути поставлених цілей і підтримувати їх, потрібно:

- заново обговорити ступінь ризику;

- визнати, що змінюватись важко, що це нормально - не досягнути успіху 3 першої спроби і що досягнення мети - це процес навчання;

- звернути увагу на позитивні моменти: хвалити за чесність і докладені зусилля, зміцнювати сильні сторони особи та підтримувати будь-які позитивні зміни;

- пов'язати пияцтво та його наслідки з проблемами особи для підвищення мотивації;

- виявити та усунути проблеми на шляху досягнення мети;

- розглянути можливе залучення батьків, якщо вони не залучені, та призначення подальшого обстеження;

- підкреслити важливість цілей і планів та обговорити, в міру необхідності, конкретні кроки їх досягнення;

- провести, завершити або оновити комплексне психосоціальне інтерв'ю.

Якщо ТАК, особа у змозі досягнути поставлених цілей і підтримувати їх, потрібно:

- зміцнювати і підтримувати продовження дотримання рекомендацій;

- звертати увагу на добре: хвалити за прогрес і підтримувати сильні і здорові рішення;

- виявити майбутні цілі, побудовані на попередніх досягненнях;

- провести, завершити або оновити комплексне психосоціальне інтерв’ю. У всіх випадках треба повторювати скринінг щорічно.

\section{CRAFFT - Скринінг на поведінкові розлади внаслідок вживання алкоголю та наркотиків для молоді Запитання 15 в опитувальнику ULS для дітей (Додаток 4)}

Посилання: Knight JR, Shrier LA, Bravender TD, Farrell M, Vander Bilt J, Shaffer HJ. A new brief screen for adolescent substance abuse. Arch Pediatr Adolesc Med 1999;153(6):591-6. Knight JR, Sherritt L, Shrier LA, Harris SK, Chang G. Validity of the CRAFFT substance abuse screening test among adolescent clinic patients. Arch Pediatr Adolesc Med 2002;156(6):607-14. Knight JR, et al. A new brief screen for adolescent substance abuse. Arch Pediatr Adolesc Med. 1999 Jun;153(6):591-6. PMID: 10357299 Dhalla S, et al. A review of the psychometric properties of the CRAFFT instrument: 1999-2010. Curr Drug Abuse Rev. 2011 Mar 1;4(1):57-64. PMID: 21466499

Скринінг на поведінкові розлади внаслідок вживання алкоголю та наркотиків для молоді. CRAFFT - Screening Tool for Adolescent Substance Abuse - опитувальник 
спрямований на виявлення проблем внаслідок споживання алкоголю та наркотиків в останні 12 місяців. Містить 6 запитань (частина В) та вступну частину (частина A), яка об'єднана нами з коротким скринінгом NIAAA (запитання 4-6 в опитувальнику ULS для дітей, додаток 4). Частина А - запитання про вживання алкоголю, марихуани або інших наркотиків протягом останніх 12 місяців (в опитувальнику ULS - тютюну, алкоголю та наркотиків). Якщо надано позитивну відповідь на будь-яке запитання вступної частини - задають питання частини В (на які передбачено відповіді «Так» чи «Ні»).

Назва CRAFFT виходить 36 показників, що він вимірює у частині B:

1. C - CAR. Ти коли-небудь їздив/ла у машині, за кермом якої була людина під впливом алкоголю чи наркотичних речовин?

2. R - RELAX. Чи використовував/ла ти алкоголь чи наркотичні речовини, щоб розслабитися або щоб відчувати себе кращою людиною чи краще вписатися в компанію?

3. A - ALONE. Чи використовував/ла ти алкоголь чи наркотичні речовини без інших - насамоті?

4. F - FORGET. Чи бувало таке, що не пам'ятаєш, що ти робив/ла коли вживав/ла алкоголь чи наркотичні речовини?

5. F - FAMILY or FRIENDS. Чи бувало таке, що хтось з рідних чи друзів казав, що тобі треба зменшити (припинити) вживання алкоголю чи наркотичних речовин?

6. T - TROUBLE. Чи виникали в тебе будь-які проблеми чи труднощі через те, що ти вживав/ла алкоголь чи наркотичні речовини?

Кожна позитивна відповідь (Так) на запитання частини В рахується як 1 бал.

Результат у 2 та більше балів свідчить про ризик залежної поведінки та потребу поглибленого вивчення.

Для батьків:

AUDIT-C - скорочений варіант опитувальника АУДИТ

Запитання 12 в опитувальнику ULS для батьків (Додаток 3)

AUDIT-C - The Alcohol Use Disorders Identification Test - Consumption. Скорочений варіант опитувальника АУДИТ містить 3 запитання стосовно ризикованого споживання алкоголю, зловживання та залежності. Кожне запитання оцінюється за допомогою 5позиційної шкали Лікерта від 0 до 4 балів, загальна оцінка варіює від 0 до 12 балів.

Інтерпретація результатів здійснюється для жінок та чоловіків окремо:

- чоловіки - 4 і більше балів - проблемне вживання.

- жінки - 3 і більше балів - проблемне вживання.

Згідно з результатами скринінгу AUDIT-C у студентському модулі ULS+ (17-25 років) «проблемне вживання» виявляється у чверті чоловіків - 26,2\% (4 і більше балів) і третини жінок - 32,7 \% (3 і більше балів). А відсутність проблем з алкоголем (0 балів) спостерігається у 28,5 \% чоловіків і 19,6 \% жінок, що говорить про значно більшу обтяженість «проблемним вживанням» алкоголю жінок, порівняно з чоловіками.

Для батьків (у другій хвилі дослідження замінений на AUDIT-C):

ASSIST - Опитувальник ВO3 для скринінгу на проблеми $з$ алкоголем, тютюном та наркотиками.

Цитування: World Health Organization (WHO) ASSIST Working Group. The Alcohol, Smoking and Substance Involvement Screening Test (ASSIST): development, reliability and feasibility. Addiction 2002; 97: 1183-94. https://www.who.int/substance_abuse/activities/assist/en/

В опитувальнику ULS додано запитання 24 - про вік першої спроби, яке не входить до опитувальника ASSIST, але надає додаткову інформацію про споживання адиктивних речовин.

Опитувальник ВО3 для скринінгу на проблеми з алкоголем, тютюном та наркотиками ASSIST Alcohol, Smoking, and Substance Involvement Screening Test (WHO ASSIST Working 
Group, 2002) був розроблений для Всесвітньої організації охорони здоров'я (ВООЗ) міжнародною групою дослідників зловживання психоактивними речовинами для виявлення вживання речовин і пов'язаних з ним проблем у системі первинної та загальної медичної допомоги. ASSIST пройшов широку апробацію та валідизацію, має високу надійність, дієвість, гнучкість, всебічність і міжкультурну актуальність і може використовуватись в системі коротких втручань.

ASSIST зазвичай використовується у дослідженнях споживання різних класів наркотичних речовин як інструмент, що дозволяє визначити ступінь ризику щодо вживання кожної окремої речовини. Ступінь ризику може бути низьким, помірним та високим. Він складається із 7 запитань для кожної наркотичної речовини та 8 запитань про ін'єкційну поведінку й визначає вживання та шкоду, пов'язану з наркотиками, протягом життя та останніх 3 місяців. Ступінь ризику - низький, помірний, високий - визначає тип інтервенції: «відсутність», «коротке втручання», «коротке втручання та перенаправлення» відповідно.

\section{Інтерпретація результатів скринінгу ASSIST (та рекомендації щодо втручання)}

Для загальної оцінки розраховується сумарний бал, який визначається для кожної речовини, наведеної в таблиці 3, окремо:

(ASSIST Q1). Чи вживали Ви які-небудь з перелічених нижче речовин хоча б один раз у житті?:

Нi - 0 балів; Так - 3 бали.

Якще відповідь на всі варіанти запитання 1 «Ні» - інші запитання не встановлюються, опитування на иьому завершується

(ASSIST Q2). Як часто впродовж останніх трьох місяців Ви вживали згадані речовини?

\begin{tabular}{|l|c|c|c|c|c|}
\hline Варіант відповіді & Ніколи & 1 - 2 рази & Щомісяця & Щотижня & Щодня або майже щодня \\
\hline Кількість балів & 0 & 2 & 3 & 4 & 6 \\
\hline
\end{tabular}

Якще відповідь на всі варіанти питання 2 «Ніколи» - переходьте до питання 6

(ASSIST Q3). Як часто впродовж останніх трьох місяців у Вас було сильне бажання або нестримний потяг вжити вказані речовини?

\begin{tabular}{|l|c|c|c|c|c|}
\hline Варіант відповіді & Ніколи & $1-2$ рази & Щомісяця & Щотижня & Щодня або майже щодня \\
\hline Кількість балів & 0 & 3 & 4 & 5 & 6 \\
\hline
\end{tabular}

(ASSIST Q4). Як часто впродовж останніх трьох місяців вживання Вами перелічених речовин приводило до медичних, соціальних, юридичних або фінансових проблем?

\begin{tabular}{|l|c|c|c|c|c|}
\hline Варіант відповіді & Ніколи & $1-2$ рази & Щомісяця & Щотижня & Щодня або майже щодня \\
\hline Кількість балів & 0 & 4 & 5 & 6 & 7 \\
\hline
\end{tabular}

(ASSIST Q5). Як часто впродовж останніх трьох місяців Ви були не в змозі зробити те, що зазвичай очікується від вас через вживання вказаних речовин?

\begin{tabular}{|l|c|c|c|c|c|}
\hline Варіант відповіді & Ніколи & $1-2$ рази & Щомісяця & Щотижня & Щодня або майже щодня \\
\hline Кількість балів & 0 & 5 & 6 & 7 & 8 \\
\hline
\end{tabular}

(ASSIST Q6): Чи висловлювали будь-коли Ваші друзі, родичі або знайомі занепокоєння через вживанням Вами перелічених речовин?

(ASSIST Q7): Чи робили Ви коли-небудь безрезультатні спроби контролювати, скоротити або припинити вживання перелічених речовин?

\begin{tabular}{|l|c|c|c|}
\hline Варіант відповіді & Ні, ніколи & $\begin{array}{c}\text { Так, протягом останніх } \\
\text { 3-х місяців }\end{array}$ & $\begin{array}{c}\text { Так, але не протягом останніх } \\
\text { 3-х місяців }\end{array}$ \\
\hline Кількість балів & 0 & 6 & 3 \\
\hline
\end{tabular}

(ASSIST Q8): Чи вживали Ви коли-небудь наркотики внутрішньовенно, ін'єкційним шляхом?

\begin{tabular}{|l|c|c|c|}
\hline Варіант відповіді & Ні, ніколи & $\begin{array}{c}\text { Так, протягом останніх } \\
\text { 3-х місяців }\end{array}$ & $\begin{array}{c}\text { Так, але не протягом останніх } \\
\text { 3-х місяців }\end{array}$ \\
\hline Кількість балів & 0 & 2 & 1 \\
\hline
\end{tabular}

(ASSIST Q9 pattern of injecting): Якщо так, то як саме Ви використовували ін'єкційні 
наркотики?

За цим запитанням бали не рахуються, але воно використовується для уточнення типу інтервениії, яка потрібна:

- Варіант відповіді 1. Раз на тиждень чи рідше ніж 3 дні підряд - потрібна коротка інтервенція з оцінюванням ризиків, пов'язаних 3 ін'єкційним вживанням наркотиків.

- Варіант відповіді 2. Частіше ніж раз на тиждень чи 3 або більше днів підряд потрібна поглиблена діагностика та лікування.

Таблиця 3

Підсумкова таблиця з оцінювання ризику для кожної речовини відповідно до сумарного балу

\begin{tabular}{|l|c|c|c|}
\hline Рівень ризику: & Низький & Помірний & Високий \\
\hline Тютюнові вироби (цигарки, жувальний тютюн тощо) & $0-3$ & $4-26$ & $27+$ \\
\hline Алкогольні напої (пиво, вино, горілка, коньяк тощо) & $0-10$ & $11-26$ & $27+$ \\
\hline $\begin{array}{l}\text { Препарати коноплі (канабіс, марихуана, план, трава, } \\
\text { гашиш тощо) }\end{array}$ & $0-3$ & $4-26$ & $27+$ \\
\hline Кокаїн (крек) & $0-3$ & $4-26$ & $27+$ \\
\hline $\begin{array}{l}\text { Амфетамін та подібні до нього стимулятори (спід, } \\
\text { екстазі, метамфетамін тощо) }\end{array}$ & $0-3$ & $4-26$ & $27+$ \\
\hline Інгалянти (клей, бензин, розчинник тощо) & $0-3$ & $4-26$ & $27+$ \\
\hline $\begin{array}{l}\text { Седативні та снодійні препарати (барбітурати, } \\
\text { транквілізатори тощо) }\end{array}$ & $0-3$ & $4-26$ & $27+$ \\
\hline Галюциногени (ЛСд, гриби, РСР, кетамін тощо) & $0-3$ & $4-26$ & $27+$ \\
\hline Опіоїди (героїн, морфін, метадон, кодеїн тощо) & $0-3$ & $4-26$ & $27+$ \\
\hline Інші наркотики (якщо вказано що саме) & $0-3$ & $4-26$ & $27+$ \\
\hline
\end{tabular}

Необхідні дії (тип потрібної інтервенції) відповідно до визначеного рівня ризику:

- Низький ризик - відсутність інтервенції. Патерн вживання речовини спричиняє низький ризик виникнення проблем із здоров'ям пацієнта.

- Помірний ризик - потрібне коротке втручання. Патерн вживання речовини спричиняє помірний ризик виникнення проблем із здоров'ям пацієнта та супутніх соціальних проблем.

- Високий ризик - потрібне коротке втручання та перенаправлення на поглиблену діагностику та лікування. Патерн вживання речовини спричиняє високий ризик виникнення серйозних проблем із здоров'ям пацієнта та супутніх соціальних проблем (порушення соціальних зв'язків, фінансові проблеми, проблеми із законом). Пацієнт, скоріше за все, залежний від конкретної речовини.

Вимірювання залежної поведінки в наступних хвилях та додаткових модулях (у дітей):

DDHF - Форма історії споживання алкоголю та наркотиків для дітей

Форма історії споживання алкоголю та наркотиків для дітей DDHF - Drinking and Drug History Form for Children/Youth (Zucker \& Jester, 2004) - є дитячою версією «Форми історії споживання алкоголю та наркотиків для дорослих», використаної у Мічиганському лонгітюдному дослідженні. Запитання змінено, щоб бути актуальними для дітей, починаючи 311 років, але вони охоплюють ті ж основні сфери (кількість, частота та об'єми споживання алкоголю; частота вживання наркотиків) та запитання щодо наслідків і проблем, пов'язаних iз вживанням хімічних речовин.

BSTAD - Короткий інструмент скринінгу споживання тютюну, алкоголю та наркотиків для підлітків

Короткий інструмент скринінгу споживання тютюну, алкоголю та наркотиків для підлітків BSTAD є поширеним інструментом для виявлення проблемного вживання тютюну, алкоголю та марихуани в педіатричних умовах. Навіть низька частота вживання речовин серед 
підлітків за результатами досліджень з використанням цього опитувальника може свідчити про необхідність втручання (Pediatrics 2014;133:819-826).

TAPS - Інструмент вимірювання споживання тютюну, алкоголю, ліків та інших речовин

Інструмент вимірювання споживання тютюну, алкоголю, ліків та інших речовин TAPS - The Tobacco, Alcohol, Prescription medication, and other Substance use tool - складається 3 комбінованого двохкомпонентного скринінгу (TAPS-1) 3 подальшою короткою оцінкою i (TAPS-2) для тих, хто показав позитивний результат на перший компонент. Цей інструмент: поєднує скринінг і коротку оцінку для найбільш поширених речовин, усуваючи необхідність у кількох скринінгах і тривалих інструментах оцінки; забезпечує двоступеневу коротку оцінку, адаптовану з швидкого скринінгу NIDA та коротку оцінку споживання речовин (адаптований ASSIST-lite); може самостійно заповнюватись пацієнтом, має електронний формат (доступний як онлайн-інструмент); спрямований на оцінку частоти споживання речовин у минулому році та 90-денний період оцінки проблемного споживання.

RAPI -Індекс алкогольних проблем Рутгера

Індекс алкогольних проблем Рутгера (RAPI - Rutgers Alcohol Problem Index) - це 23позиційний самостійний скринінговий інструмент для оцінки проблеми підліткового вживання алкоголю. Був розроблений 3 метою створення концептуально повного, одномірного, відносно короткого і легкого для заповнення інструменту оцінки проблем споживання алкоголю в підлітковому віці. Скорочена версія включає 18 запитань (White \& Labouvie, 2000). С модифікована версія RAPI для оцінки проблем 3 наркотиками (е.g., Johnson \& White, 1995; Simons et al., 1998).

\section{Ciм'я}

Для дітей та батьків (багатовимірний опитувальник):

APQ - Сімейний Алабамський опитувальник

Запитання 6-7 в опитувальнику ULS для дітей (Додаток 4)

Запитання 10 в опитувальнику ULS для батьків (Додаток 3)

Посилання: Dadds, M. R., Maujean, A., \& Fraser, J. А. (2003). Parenting and conduct problems in children: Australian data and psychometric properties of the Alabama Parenting Questionnaire. Australian Psychologist, 38, 238-241. Elgar, F.J., Waschbusch, D.A., Dadds, M.R., \& Sivaldason, N. (2007). Development and validation of a short form of the Alabama Parenting Questionnaire. Journal of Child and Family Studies, 16, 243-259. Essau, C. A, Sasagawa, S., \& Frick, P.J. (2006). Psychometric properties of the Alabama Parenting Questionnaire. Journal of Child and Family Studies, 15, 597-616 Clerkin, S.M., Marks, D.J., Policaro, K., \& Halperin, J.M. (2007). Psychometric properties of the Alabama Parenting Questionnaire-Preschool Revision. Journal of Clinical Child and Adolescent Psychology, 36, 19-28. Публікації доступні за посиланням: http://fs.uno.edu/pfrick/APQ.html

APQ - Alabama Parenting Questionnaire (Frick, 1991). Сімейний Алабамський опитувальник (APQ) містить 42 запитання, об'єднані у п'ять груп показників щодо виховання дітей, пов'язані з етіологією та лікуванням поведінкових проблем дитини: 1) Включеність (Involvement); 2) Позитивне виховання (Positive Parenting); 3) Нагляд і моніторинг (Роor Monitoring/Supervision); 4) Дисципліна (Inconsistent Discipline); 5) Використання тілесних покарань (Corporal Punishment). Додаткова шкала «Інші дисциплінарні практики» (Other Discipline Practices) надає окрему інформацію про особливості виховання дитини. Існує як батьківська, так і дитяча форма опитувальника. Обидві мають 42 ідентичні запитання, що дозволяє порівняти інформацію від дитини та батьків про особливості виховання. APQ має добрі психометричні властивості, високу критеріальну валідність у диференціації клінічних і неклінічних груп піддослідних (Dadds, Maujean, \& Fraser, 2003; Frick, Christian, \& Wooton, 1999; Shelton et al., 1996).

\section{Розрахунок балів за шкалами APQ}

Перша частина опитувальника для дитини включає в себе запитання про структуру родини, яка вимірюється двома показниками - хто $є$ важливою людиною та хто мешкає разом 3 дитиною. Шкала включає 10 позицій, 6 для визначених сімейних ролей (Мати, 
Батько, Бабуся, Дідусь, Тітка, Дядько) та 4 додаткові - інша важлива людина, з можливістю позначити, хто саме $\epsilon$ цією важливою людиною.

Друга частина опитувальника розділена на 5 шкал, за якими підраховується сумарний бал. Номери запитань опитувальників для дітей та батьків однакові. За додатковою 6-ю шкалою «інші дисциплінарні практики» сумарний бал не рахується, але кожне запитання якої надає окрему інформацію про особливості виховання дитини.

1. Залученість (Involvement): 1, 4, 7, 9, 11, 14, 15, 20, 23, 26 (в опитувальнику ULS кожне запитання розділено на три частини - відносно батька, мати та іншої важливої людини, яка, можливо, виховує дитину. Якщо такої людини немає, запитання пропускається).

2. Позитивне виховання (Positive Parenting): 2, 5, 13, 16, 18, 27.

3. Нагляд і моніторинг (Poor Monitoring/Supervision): 6, 10, 17, 19, 21, 24, 28, 29, 30, 32.

4. Дисципліна (Inconsistent Discipline): 3, 8, 12, 22, 25, 31.

5. Використання тілесних покарань (Corporal Punishment): 33, 35, 38.

6. Інші дисциплінарні практики (Other Discipline Practices) сума балів по цій шкалі не рахується, інтерпретація здійснюється змістовно, по кожному запитанню окремо: $34,36,37,39,40,41,42$.

Підрахунок балів здійснюється простим підсумуванням загальної кількості балів по кожному запитанню, що відноситься до шкали. Реверсивного кодування немає. Розробники для зручності радять відняти кількість запитань шкали від загальної кількості балів, щоб шкала починалась від нуля.

Бали за варіантами відповіді рахуються таким чином:

- Ніколи - 1 бал;

- Майже ніколи - 2 бали;

- Іноді- 3 бали;

- Часто - 4 бали;

- Постійно - 5 балів.

Сталого нормування за шкалами немає, оскільки практики виховання залежать від культурних особливостей. Кількісний аналіз відбувається шляхом порівняння відповідей дитини та дорослих між собою.

\section{Для батьків:}

\section{АСЕ - Опитувальник шкідливого досвіду дитинства}

Для батьків у другій хвилі дослідження не використовується, присутній у студентському модулі ULS+

Посилання: Center for Disease and Prevention. (2003). ACE Reporter: Origins and Essence of the Study. San Diego. Dong, M, Anda, R.., Felitti, V.J., Dube, S.R., Williamson, D.F., Thompson, T.J., Loo, C.M., and Giles, W.H. (2004). The interrelatedness of multiple forms of childhood abuse, neglect, and household dysfunction. Child Abuse and Neglect, 28 (7), 771-784. Felitti, V.J., Anda, R.F., Nordenberg, D, Williamson, D.F., Spitz A.M., Edwards, V.K., Koss, M.P., and Marks, J.S., (1998). Relationship of childhood abuse and household dysfunction to many of the leading causes of death in adults: The Adverse Childhood Experiences (ACE) Study. American Journal of Preventative Medicine, vol 14 (4), 245-258. Injury Prevention and Control: Division of Violence Prevention. (2014) http://www.cdc.gov/violenceprevention/acestudy.

ACE - Adverse Childhood Experiences Questionnaire (Anda, 2006). Опитувальник шкідливого досвіду дитинства (АСЕ) призначений для вимірювання зв'язку між різними типами шкідливого досвіду та наслідками для здоров'я у майбутньому. Опитувальник має 10 запитань і охоплює 10 видів дитячих психотравм або типів шкідливого досвіду дитинства, які включають: емоційне та фізичне насильство; нехтування родинними обов'язками; досвід, пов'язаний з життям у дисфункціональній родині; гендерно-обумовлене насильство; втрата батьків; розлучення; ув'язнення члена родини тощо. Незважаючи на сенситивність питань, ретестова надійність для кожного фактору оцінки була в діапазоні від доброї до відмінної (каппа Коена: 0,46-0,86) (Dube 2004). Також дослідники не знайшли жодних доказів 
упередженості у відповідях або щоб респонденти були упередженими до приписування своїх проблем зі здоров'ям до досвіду дитинства, що робить цей інструмент дуже привабливим для діагностики проблем дитинства у дорослих (Edwards and Anda 2001).

Починаючи з 1994 року, у США триває дослідження ACE (ACE Study http://www.aceresponse.org), що проводиться однією 3 найпотужніших дослідницьких організацій у світі - Центром по контролю за захворюваннями - Centers for Disease Control (CDC). Дослідження показує стійку асоціацію високих балів ACE з ризикованою поведінкою дорослих щодо власного здоров'я та сімейними дисфункціями. До факторів, пов'язаних 3 високим балом АCE, відноситься погане загальне соматичне здоров'я, зловживання алкоголем, наркотиками, депресія, суїцидальна поведінка, ожиріння, ризикована сексуальна поведінка та захворювання, що передаються статевим шляхом тощо.

\section{Підрахунок балів:}

Відповіді на запитання бінарні - «Так» чи «Ні». Кожна відповідь «Так» - 1 бал. Сума балів за всіма запитанням - загальний бал по опитувальнику, максимально - 10 балів. Чим вищий бал, тим більша обтяженість наслідками шкідливого досвіду дитинства.

\section{Бланк опитувальника АСЕ}

Чи відбувались у Вашому дитинстві наступні події?

\begin{tabular}{|c|c|c|}
\hline Обведіть або закресліть номер обраної відповіді: & Так & Hi \\
\hline $\begin{array}{l}\text { 1.1. Часто батьки або інші дорослі в сім'ї матюкалися до Вас, ображали або } \\
\text { принижували? }\end{array}$ & 1 & 2 \\
\hline $\begin{array}{l}\text { 1.2. Батьки або інші дорослі часто так поводилися, що вам було страшно, що } \\
\text { Вам заподіють фізичної шкоди? }\end{array}$ & 1 & 2 \\
\hline $\begin{array}{l}\text { 2.1. Часто батьки або інші дорослі в сім'ї штовхали Вас, тягали, давали ляпаса } \\
\text { (били долонею по обличчю) чи чимось у Вас жбурляли? }\end{array}$ & 1 & 2 \\
\hline $\begin{array}{l}\text { 2.2. Часто батьки били Вас так, що потім залишалися сліди, синці або } \\
\text { поранення? }\end{array}$ & 1 & 2 \\
\hline $\begin{array}{l}\text { 3.1. Дорослий або людина, принаймні на } 5 \text { років старше за Вас, коли-небудь } \\
\text { доторкалися до Вашого тіла або заставляли Вас торкатися їх із сексуальними } \\
\text { намірами? }\end{array}$ & 1 & 2 \\
\hline $\begin{array}{l}\text { 3.2. Дорослий або людина, принаймні на } 5 \text { років старше за Вас, робила спробу } \\
\text { вступити або вступала в оральний, анальний або вагінальний секс з Вами? }\end{array}$ & 1 & 2 \\
\hline $\begin{array}{l}\text { 4.1. Ви часто відчували, що ніхто у Вашій родині не любить Вас або не вважає } \\
\text { Вас значимим чи особливим? }\end{array}$ & 1 & 2 \\
\hline $\begin{array}{l}\text { 4.2. Ви часто відчували, що у Вашій родині не піклуються один про одного, не } \\
\text { відчувають взаємної близькості чи не підтримують один одного? }\end{array}$ & 1 & 2 \\
\hline $\begin{array}{l}\text { 5.1. Ви часто відчували, що не було достатньо їжі, доводилося носити брудний } \\
\text { одяг і не було нікого, хто б Вас захистив? }\end{array}$ & 1 & 2 \\
\hline $\begin{array}{l}\text { 5.2. Ви часто відчували, що Ваші батьки були занадто п'яні, щоб піклуватися } \\
\text { про Вас чи вести Вас до лікаря, якщо це було потрібно? }\end{array}$ & 1 & 2 \\
\hline 6. Чи були Ваші батьки коли-небудь розлучені або проживали окремо? & 1 & 2 \\
\hline $\begin{array}{l}\text { 7.1. Вашу маму або мачуху часто штовхали, хапали, били або чимось в неї } \\
\text { жбурляли? }\end{array}$ & 1 & 2 \\
\hline $\begin{array}{l}\text { 7.2. Вашу маму або мачуху інколи (чи часто) били ногами, кусали, били } \\
\text { кулаком або чимось твердим? }\end{array}$ & 1 & 2 \\
\hline $\begin{array}{l}\text { 7.3. Вашу маму або мачуху коли-небудь без перестану били принаймні кілька } \\
\text { хвилин або погрожували пістолетом або ножем? }\end{array}$ & 1 & 2 \\
\hline $\begin{array}{l}\text { 8. Чи жили Ви з тими, хто пив багато алкоголю (був алкоголіком) або вживав } \\
\text { наркотики? }\end{array}$ & 1 & 2 \\
\hline $\begin{array}{l}\text { 9. Чи був у Вашій родині член сім'ї, який був психічно хворим, мав депресію } \\
\text { або робив спроби самогубства? }\end{array}$ & 1 & 2 \\
\hline 10. Чи був у Вашій родині член сім'ї, який «сидів» у тюрмі? & 1 & 2 \\
\hline
\end{tabular}


Вимірювання сімейної згуртованості в наступних хвилях та додаткових модулях (у дімей та батьків):

FACES-IV - Шкала сімейної гнучкості та згуртованості

FACES-IV - Family Adaptation and Cohesion Scales-IV (FACES; Olson \& Gorall, 2003). Шкала сімейної гнучкості та згуртованості вимірює два ключових поняття, що стосуються функціонування сім'ї - сімейну згуртованість і гнучкість сім'ї. Шкала сімейної згуртованості визначає згоду членів сім'ї з такими висловлюваннями, як: «Наша сім'я рідко робить щось разом», «Члени сім'ї беруть участь у житті один одного», тоді як гнучкість сім'ї вимірюється такими запитаннями як: «У нас є чіткі правила і ролі в нашій сім'ї» і «Коли виникають проблеми, ми доходимо до компромісу». Вимір здійснюється за 5-позиційною шкалою Лікерта. Підсумкове оцінювання визначає збалансоване і незбалансоване функціонування сім'ї. FACES також вимірює задоволеність сімейним життям та якість спілкування між членами сім'ї (Olson, 2011).

\section{Комплексний діагностичний інструмент ASEBA}

Інструменти ASEBA - Achenbach System of Empirically Based Assessment (aseba.org) мають у своїй основі однаковий набір DSM-орієнтованих шкал, що дозволяє проводити комплексну перехресну оцінку поведінкових проблем між результатами членів однієї родини (самооцінка батьків, оцінка дитини з боку батьків, самооцінка дитини). Існує також версія оцінки поведінки дитини з боку вчителя - TRF - Teacher Reference Form (в цьому дослідженні не використовується).

Комплексні діагностичні інструменти ASEBA захищені авторським правом, їх використання та поширення без дозволу авторів заборонено. Для використання усіх діагностичних інструментів ASEBA та публікації отриманих за їх допомогою результатів потрібна ліцензія, яку можливо придбати на вебсайті інституту Ахенбаха за посиланням: www.aseba.org

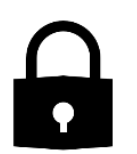

Приклади форм YSR, CBCL ma ASR наведені в цих методичних рекомендаціях виключно з ознайомчою метою для виконавців дослідження, їх використання, копіювання та розповсюдження без дозволу авторів заборонено!

Для дітей:

YSR - Самозвіт Ахенбаха для молоді

Запитання 8 в опитувальнику ULS для дітей (Додаток 4)

YSR - Achenbach System of Empirically Based Assessment (ASEBA) - Youth Self Report (YSR/11-18). Самозвіт Ахенбаха для молоді (використовується на умовах ліцензійного договору). Опитувальник для самостійного заповнення, розроблений Томасом М. Ахенбахом i отриманий 3 іншого широко використовуваного стандартизованого опитувальника в дитячій психології - Контрольного списку поведінки дітей (CBCL).

YSR був розроблений для оцінки емоційних та поведінкових проблем підлітків у стандартизованому форматі. Він оцінює інтерналізацію (тобто, тривогу, депресію i надмірний контроль) i екстерналізацію (агресію, гіперактивність, невідповідність і підконтрольність) поведінки.

Для батьків:

CBCL - Контрольний список поведінки дітей

Запитання 9 в опитувальнику ULS для батьків (Додаток 3)

CBCL - Achenbach System of Empirically Based Assessment (ASEBA) - Adult SelfReport (ASR) Child Behavior Check List (CBCL/6-18). Контрольний список поведінки дітей (використовується на умовах ліцензійного договору). Опитувальник для оцінки дітей шкільного віку CBCL / 6-18 заповнюється батьками. Емпірично орієнтовані шкали у CBCL / 6-18 i YSR базуються на факторному аналізі, згруповані у 8 шкал синдромів: 
тривожність/депресивність, замкненість/депресивність, соматичні проблеми, соціальні проблеми, проблеми мислення, проблеми уваги, порушення правил поведінки, агресивна поведінка. Опитувальник має 5 DSM-оріснтованих шкал: афективні проблеми; проблеми тривоги; соматичні проблеми; проблеми демонстративної опозиційної поведінки, проблеми контролю поведінки. Шкала Проблем дефіциту уваги / Гіперактивності не діагностується за допомогою опитувальників YSR та CBCL, присутній тільки в опитувальнику TRF, який у цій хвилі не використовується.

\section{Інтерпретація результатів YSR та CBCL}

Цитування керівництва з інтерпретаиії результатів: Achenbach, T.M., \& Rescorla, L.A. (2001). Manual for the ASEBA School-Age Forms \& Profiles. Burlington, VT: University of Vermont, Research Center for Children, Youth, \& Families

Форми YSR та CBCL складаються 3 двох частин, які розміщені на 4-х сторінках. Перша частина, розміщена на 1 та 2 сторінках опитувальника, містить загальну інформацію про дозвільну активність дитини, іiі соціальне функціонування та шкільну академічну успішність. Ця частина називається «шкалою компетентності». Дозвілля та соціальне функціонування ми досліджуємо за допомогою модифікованої версії РВР - Профілю поведінки друзів, інтегрованого нами 3 опитувальниками NIAAA та CRAFFT. Дані про академічну успішність можливо збирати централізовано, із шкільних записів. Внаслідок цього в опитувальнику ULS нами використовується лише друга частина YSR та CBCL, розміщена в оригіналі на 3 та 4 сторінках опитувальника. Ця частина називається «шкалою проблем» (запитання 8 в опитувальнику ULS для дітей та запитання 9 в опитувальнику ULS для батьків).

\section{Інструкція з інтерпретації шкали проблем:}

Загальні інструкції:

- Кожному запитанню присвоюється 0, 1 або 2 бали, згідно з цифрою відміченою респондентом.

- Сума балів по кожній шкалі складається з суми балів за окремими запитаннями.

- Не здійснювати підрахунок балів за шкалою проблем, якщо пропущені більше 8 запитань.

- Не рахуються бали для відкритих запитань - 56h та 113.

- Не рахуються бали YSR для соціально бажаних запитань - 6, 15, 49, 59, 60, 73, 80, 88, 92, 98, 106, 107, 108, 109. (Рахуються тільки для CBCL).

- Сума балів по шкалі загальних проблем не окремо рахується, але входить до підрахунку загального балу за опитувальником.

- Загальний бал за опитувальником рахується як відсоток набраних балів від максимально можливої кількості балів. Нормальний діапазон - до $64 \%$, пограничний - 65-69\%, клінічний $-70 \%$ і більше.

В таблиці 4 наведено номери запитань, які відносяться до відповідних шкал синдромів YSR та CBCL.

В таблиці 5 наведено номери запитань, які відносяться до відповідних DSMоріснтованих шкал YSR та CBCL.

\section{ASR - Самозвіт Ахенбаха для дорослих}

\section{Запитання 11 в опитувальнику ULS для батьків (Додаток 3)}

ASR - Achenbach System of Empirically Based Assessment (ASEBA) - Adult Self-Report (ASR) (Achenbach \& Rescorla, 2003). Самозвіт Ахенбаха для дорослих (використовується на умовах ліцензійного договору). ASR опитувальник для самостійного заповнення. Цей інструмент забезпечує об'єктивну оцінку соціального та емоційного функціонування людини. Інструмент валідизований для дорослих у віці 18-59 років і надає стандартизовані оцінки по 8 вузьких діагностичних субшкалах та двох широких субшкалах, які стосуються екстерналізації - інтерналізації поведінки і загальних проблем поведінки. Опитувальник має 6 DSM-орієнтованих шкал: 1) депресивні проблеми; 2) проблеми 
тривоги; 3) соматичні проблеми; 4) уникаючий розлад особистості; 5) проблеми дефіциту уваги /гіперактивності; 6) проблеми антисоціальної особистості - «Порушення правил поведінки». Ретестова перевірка показала високу надійність інструменту (Achenbach \& Rescorla, 2003).

Таблиця 4

Шкали синдромів YSR та CBCL

\begin{tabular}{|c|c|c|c|c|c|c|c|c|}
\hline \multicolumn{3}{|c|}{$\begin{array}{c}\text { Internalizing } \\
\text { Інтерналізована поведінка }\end{array}$} & \multirow[b]{2}{*}{$\begin{array}{c}\text { Social } \\
\text { Prohlems } \\
\text { Соціальні } \\
\text { проблеми }\end{array}$} & \multirow[b]{2}{*}{$\begin{array}{l}\text { Thought } \\
\text { Problems } \\
\text { Проблеми } \\
\text { мислення }\end{array}$} & \multirow[b]{2}{*}{$\begin{array}{l}\text { Attention } \\
\text { Problems } \\
\text { Проблеми } \\
\text { уваги }\end{array}$} & \multicolumn{2}{|c|}{$\begin{array}{c}\text { Externalizing } \\
\text { Екстерналізована } \\
\text { поведінка } \\
\end{array}$} & \multirow[b]{2}{*}{$\begin{array}{c}\text { Other problem } \\
\text { Інші } \\
\text { проблеми }\end{array}$} \\
\hline $\begin{array}{c}\text { Anxious/ } \\
\text { Depressed } \\
\text { Тривожність/ } \\
\text { депресивніст } \\
\mathbf{b} \\
\end{array}$ & \begin{tabular}{|c|} 
Withdrawn/ \\
Depressed \\
Замкненість/ \\
депресивніст \\
$\mathbf{b}$ \\
\end{tabular} & $\begin{array}{c}\text { Somatie } \\
\text { Complaints } \\
\text { Соматичні } \\
\text { проблеми }\end{array}$ & & & & \begin{tabular}{|c|} 
Rule- Breaking \\
Behavior \\
Порушення \\
правил \\
поведінки \\
\end{tabular} & $\begin{array}{l}\text { Aggressive } \\
\text { Behavior } \\
\text { Агресивна } \\
\text { поведінка }\end{array}$ & \\
\hline 14 & 5 & 47 & 11 & 9 & 1 & 2 & 3 & 6 \\
\hline 29 & 42 & 49 (CBCL) & 12 & 18 & 4 & 26 & 16 & 7 \\
\hline 30 & 65 & 51 & 25 & 40 & 8 & 28 & 19 & 15 \\
\hline 31 & 69 & 54 & 27 & 46 & 10 & 39 & 20 & 24 \\
\hline 32 & 75 & $56 a$ & 34 & 58 & 13 & 43 & 21 & 44 \\
\hline 33 & 102 & $56 \mathrm{~b}$ & 36 & 59 (CBCL) & 17 & 63 & 22 & 53 \\
\hline 35 & 103 & $56 \mathrm{c}$ & 38 & 60 (CBCL) & 41 & 67 & 23 & 55 \\
\hline 45 & 111 & $56 \mathrm{~d}$ & 48 & 66 & 61 & 72 & 37 & $56 \mathrm{~h}$ \\
\hline 50 & & $56 \mathrm{c}$ & 62 & 70 & 78 & 73 (CBCL) & 57 & 74 \\
\hline 52 & & $56 f$ & 64 & 76 & 80 (CBCL) & 81 & 68 & 77 \\
\hline 71 & & $56 \mathrm{~g}$ & 79 & 83 & 92 & 82 & 86 & 93 \\
\hline 91 & & & & 84 & & 90 & 87 & 98 \\
\hline 112 & & & & 85 & & 96 & 88 (CBCL) & 107 \\
\hline & & & & 92 (CBCL) & & 99 & 89 & 108 \\
\hline & & & & 100 & & 101 & 94 & 109 \\
\hline & & & & (CBCL) & & 105 & 95 & 113 \\
\hline & & & & & & 106 & 97 & \\
\hline & & & & & & (CBCL) & 104 & \\
\hline \multicolumn{9}{|c|}{ Нормальний діапазон суми балів за шкалами* } \\
\hline $0-6$ & $0-5$ & $0-4$ & $0-5$ & $0-4$ & $0-10$ & $0-8$ & $0-12$ & - \\
\hline \multicolumn{9}{|c|}{ Пограничний діапазон суми балів за шкалами* } \\
\hline $7-9$ & $6-7$ & 5 & $6-8$ & $5-7$ & $11-13$ & $9-12$ & $13-16$ & - \\
\hline \multicolumn{9}{|c|}{ Клінічний діапазон суми балів за шкалами* } \\
\hline $10-26$ & $8-16$ & $6-22$ & $9-22$ & $8-30$ & $14-20$ & $13-34$ & $17-36$ & - \\
\hline
\end{tabular}

* норми вказані з демонстраційною метою $i$ не повинні використовуватись для иілей індивідуальної діагностики. Керівництво з інтерпретації результатів захищено авторським правом, нормування здійснено для американської популящії. Досліджень з використанням інструментів ASEBA в Україні не проводилось. Норми гендерно чутливі та варіюються за віком.

\section{Інтерпретація результатів ASR:}

Форма ASR, як і YSR та CBCL, складається з двох частин, які в оригіналі розміщені на 4-х сторінках. Перша частина, розміщена на 1-й та 2-й сторінках оригінального опитувальника, містить загальну інформацію про соціальне функціонування дорослого. Ця частина називається «шкалою адаптивного функціонування» (запитання 9-17 опитувальнику ULS для батьків). Друга частина ASR розміщена в оригіналі на 3-й та 4-й сторінках опитувальника i називається «шкалою синдромів» (запитання 19 в опитувальнику ULS для батьків). 
DSM-оріснтовані шкали YSR та CBCL

\begin{tabular}{|c|c|c|c|c|}
\hline $\begin{array}{c}\text { Affective } \\
\text { Problems } \\
\text { (including } \\
\text { Dysthymia and } \\
\text { Major } \\
\text { Depression) } \\
\text { Афективні } \\
\text { проблеми } \\
\text { (включаючи } \\
\text { дистимію та } \\
\text { депресію) }\end{array}$ & $\begin{array}{l}\text { Anxiety Problems (including } \\
\text { Generalized Anxiety } \\
\text { Disorder (GAD), Separation } \\
\text { Anxiety Disorder (SAD), and } \\
\text { Specific Phobia) } \\
\text { Проблеми тривоги } \\
\text { (включаючи } \\
\text { генералізований та } \\
\text { відокремлений тривожні } \\
\text { розлади та фобію) }\end{array}$ & $\begin{array}{l}\text { Somatic Problems } \\
\text { (including } \\
\text { Somatization and } \\
\text { Somatoform) } \\
\text { Соматичні } \\
\text { проблеми } \\
\text { (включаючи } \\
\text { соматизований та } \\
\text { соматоформний } \\
\text { розлади) }\end{array}$ & $\begin{array}{c}\text { Oppositional } \\
\text { Defiant Problems } \\
\text { Проблеми } \\
\text { демонстративної } \\
\text { опозиційної } \\
\text { поведінки }\end{array}$ & $\begin{array}{c}\text { Conduct } \\
\text { Problems } \\
\text { Проблеми } \\
\text { контролю } \\
\text { поведінки }\end{array}$ \\
\hline $\begin{array}{c}5 \\
14 \\
18 \\
24 \\
35 \\
52 \\
54 \\
76 \\
77 \\
91 \\
100 \\
102 \\
103\end{array}$ & $\begin{array}{c}11 \\
29 \\
30 \\
45 \\
50 \\
112\end{array}$ & $\begin{array}{l}56 \mathrm{a} \\
56 \mathrm{~b} \\
56 \mathrm{c} \\
56 \mathrm{~d} \\
56 \mathrm{e} \\
56 \mathrm{f} \\
56 \mathrm{~g}\end{array}$ & $\begin{array}{c}3 \\
22 \\
23 \\
86 \\
95\end{array}$ & $\begin{array}{c}15 \\
16 \\
21 \\
26 \\
28 \\
37 \\
39 \\
43 \\
57 \\
67 \\
72 \\
73 \\
81 \\
82 \\
90 \\
97 \\
101 \\
106\end{array}$ \\
\hline
\end{tabular}

\section{Шкала адаптивного функціонування:}

Шкала адаптивного функціонування включає в себе запитання про роботу, друзів, сім'ю, подружні стосунки або стосунки 3 партнером. Бали за «шкалою адаптивного функціонування» рахуються як сума усіх балів за кожним запитанням.

Загальний бал - сума введених значень по усіх 3-х шкалах. У нормі загальний бал повинен бути більше 40, діапазон 37-39 - це пограничний рівень, 36 і менше - вказує на наявність розладу соціального функціонування.

\section{Шкала вживання хімічних речовин:}

Окремо рахуються бали за шкалою «вживання хімічних речовин». Вона включає в себе запитання 124,125 та 126 :

- 124 - вживання тютюну (рахується кількість вживання разів на день протягом останніх 6 місяців);

- 125 - вживання алкоголю (рахується кількість днів «напідпитку» протягом останніх 6 місяців);

- 126 - вживання наркотиків (рахується кількість днів вживання протягом останніх 6 місяців).

Загальний бал - сума введених значень по усіх 3-х шкалах. У нормі загальний бал повинен бути менше 61, діапазон 62-65 - це пограничний рівень, 66 і більше - вказує на клінічний розлад. 
Інструкція з інтерпретації шкали синдромів:

Загальні інструкиї:

- Кожному запитанню присвоюється 0, 1 або 2 бали, згідно з варіантом відповіді, відміченим респондентом.

- Сума балів по кожній шкалі складається з суми балів по окремим запитанням.

- Не здійснювати підрахунок балів за шкалою проблем, якщо пропущені більше 8 запитань.

В таблиці 6 наведено номери запитань, які відносяться до відповідних шкал синдромів ASR.

Таблиця 6

Шкали синдромів ASR

\begin{tabular}{|c|c|c|c|c|c|c|c|c|}
\hline \multicolumn{3}{|c|}{$\begin{array}{c}\text { Internalizing } \\
\text { Iнтерналізована поведінка }\end{array}$} & \multirow[b]{2}{*}{$\begin{array}{c}\text { Thought } \\
\text { Problems } \\
\text { Проблеми } \\
\text { мислення }\end{array}$} & \multirow[b]{2}{*}{$\begin{array}{c}\text { Attention } \\
\text { Problems } \\
\text { Проблеми } \\
\text { уваги }\end{array}$} & \multicolumn{3}{|c|}{$\begin{array}{c}\text { Externalizing } \\
\text { Екстерналізована поведінка }\end{array}$} & \multirow[b]{2}{*}{$\begin{array}{c}\text { Other } \\
\text { problems } \\
\text { Інші } \\
\text { проблеми }\end{array}$} \\
\hline $\begin{array}{c}\text { Anxious/ } \\
\text { Depressed } \\
\text { Тривожність/ } \\
\text { депресивніст } \\
\text { ь }\end{array}$ & $\begin{array}{l}\text { Withdrawn } \\
\text { Замкненість }\end{array}$ & $\begin{array}{c}\text { Somatie } \\
\text { Complaints } \\
\text { Соматичні } \\
\text { проблеми }\end{array}$ & & & $\begin{array}{c}\text { Aggressive } \\
\text { Behavior } \\
\text { Агресивна } \\
\text { поведінка }\end{array}$ & $\begin{array}{c}\text { Rule- Breaking } \\
\text { Behavior } \\
\text { Порушення } \\
\text { правил } \\
\text { поведінки }\end{array}$ & \begin{tabular}{|c} 
Intrusive \\
Нав'язливі \\
стани
\end{tabular} & \\
\hline 12 & 25 & $56 a$ & 9 & 1 & 3 & 6 & 7 & 10 \\
\hline 13 & 30 & $56 b$ & 18 & 8 & 5 & 23 & 19 & 21 \\
\hline 14 & 42 & $56 c$ & 36 & 11 & 16 & 26 & 74 & 24 \\
\hline 22 & 48 & $56 \mathrm{~d}$ & 40 & 17 & 28 & 39 & 93 & 27 \\
\hline 31 & 60 & $56 \mathrm{e}$ & 46 & 53 & 36 & 41 & 94 & 29 \\
\hline 33 & 65 & $56 f$ & 63 & 59 & 55 & 43 & 104 & 32 \\
\hline 34 & 67 & $56 \mathrm{~g}$ & 66 & 61 & 57 & 76 & & 38 \\
\hline 35 & 69 & $56 \mathrm{~h}$ & 70 & 64 & 68 & 82 & & 44 \\
\hline 45 & 111 & $56 \mathrm{i}$ & 84 & 78 & 81 & 90 & & 58 \\
\hline 47 & & 100 & 85 & 101 & 86 & 92 & & 62 \\
\hline 50 & & & & 102 & 87 & 114 & & 72 \\
\hline 52 & & & & 105 & 95 & 117 & & 75 \\
\hline 71 & & & & 108 & 97 & 122 & & 77 \\
\hline 91 & & & & 119 & 116 & & & 79 \\
\hline 103 & & & & 121 & 118 & & & 83 \\
\hline 107 & & & & & & & & 89 \\
\hline 112 & & & & & & & & 99 \\
\hline 113 & & & & & & & & 110 \\
\hline & & & & & & & & 115 \\
\hline & & & & & & & & 120 \\
\hline \multicolumn{9}{|c|}{ Нормальний діапазон суми балів за шкалами } \\
\hline $0-15$ & $0-5$ & $0-7$ & $0-5$ & $0-13$ & $0-12$ & $0-7$ & $0-5$ & - \\
\hline \multicolumn{9}{|c|}{ Пограничний діапазон суми балів за шкалами } \\
\hline 16-19 & $6-8$ & $8-10$ & $6-7$ & $14-15$ & $13-17$ & $8-9$ & $6-7$ & - \\
\hline \multicolumn{9}{|c|}{ Клінічний діапазон суми балів за шкалами } \\
\hline $20-36$ & $9-18$ & $11-24$ & $8-20$ & $16-30$ & $18-30$ & $10-28$ & $8-12$ & - \\
\hline
\end{tabular}

* норми вказані з демонстраційною метою $i$ не повинні використовуватись для иілей індивідуальної діагностики. Керівництво з інтерпретації результатів захищено авторським правом, нормування здійснено для американської популяції. Досліджень з використанням інструментів ASEBA в Украӥні не проводилось. Норми гендерно чутливі та варіюються за віком.

В таблиці 7 наведено номери запитань, які відносяться до 5 відповідних DSMорієнтованих шкал ASR. 
Шкали DSM-оріснтованих шкал ASR

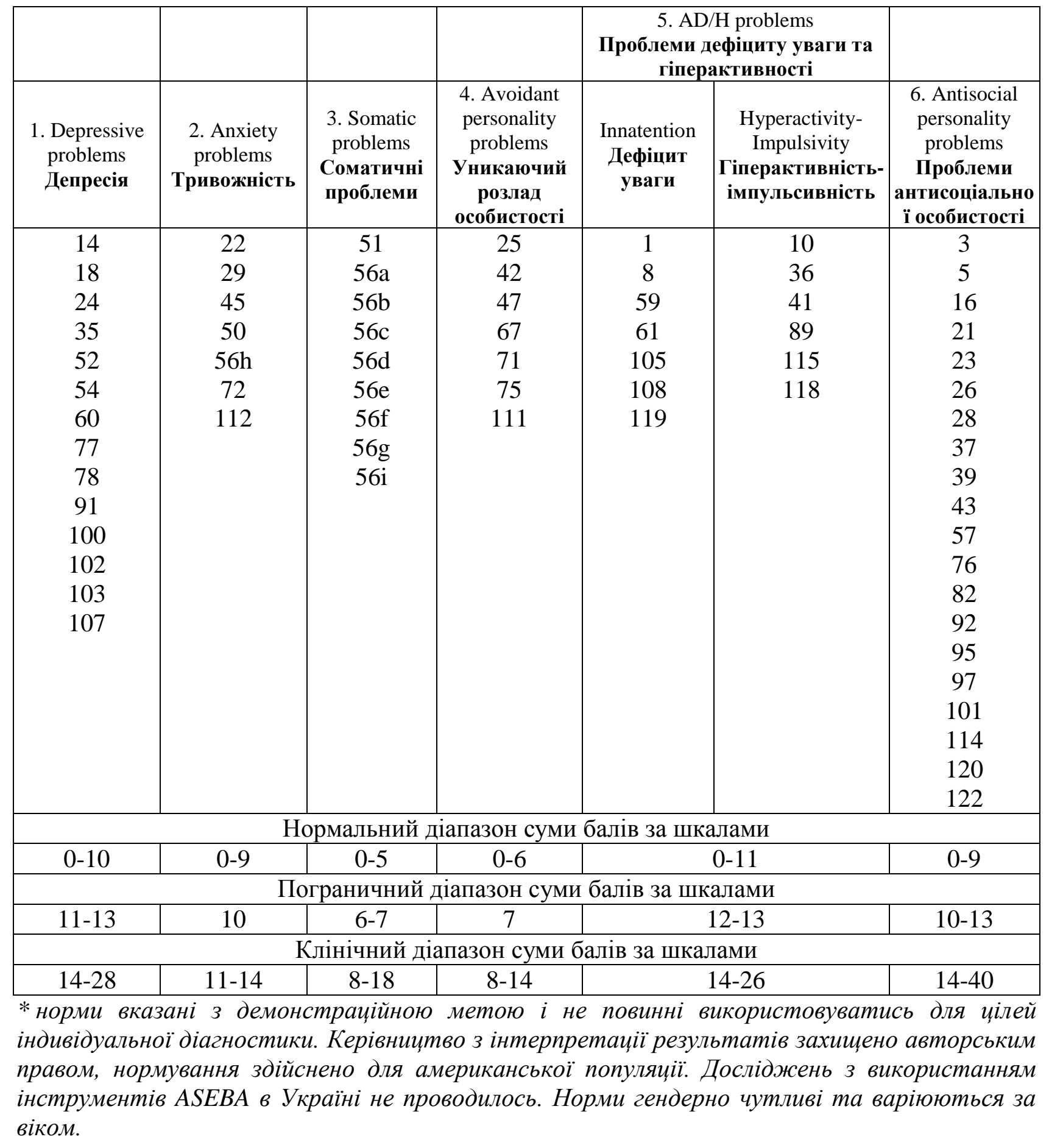

Друзі

Для дітей:

РВР - Профіль поведінки друзів

Запитання 9, 10, 11 та 16 в опитувальнику ULS для дітей (Додаток 4)

PBP - Peer Behavior Profile (Bingham, Fitzgerald \& Zucker (1995). Профіль поведінки друзів (модифікована українська версія включає додаткові форми поведінки друзів). Оригінальний опитувальник для самостійного заповнення включає 54 запитання (17 запитань у скороченій українській версії та 3 додаткових запитання про залежну поведінку друзів, інтегровані з опитувальниками NIAAA та CRAFFT). Оцінювання здійснюється за 5позиційною шкалою Лікерта. Запитання сформульовані на основі теорії соціального контролю відповідно до основних інститутів соціального контролю - сім'я, школа, загальні 
соціальні та законодавчі норми (Social Control Theory, Hirschi, 1969), на основі теорії проблемної поведінки - конвенційна та неконвекційна поведінка (Problem Behavior Theory, Jessor et al., 1983; Jessor \& Jessor, 1977), що включає легкі форми соціальних відхилень, делінквентну поведінку, сексуальну поведінку, алкоголь та наркотики. Частково запитання запозичені з Контрольного списку антисоціальної поведінки (Antisocial Behavior Checklist delinquent/illegal behaviors; Zucker et al., 1994; Zucker \& Noll, 1980). Оригінальна шкала якості підтримки друзів є субшкалою опитувальника Самооцінки Я-образу для дітей (Self-Image Questionnaire for Young Adolescents; Petersen, Schulenburg, Abramowitz, Offer, \& Jarcho, 1984).

В опитувальнику ULS для дітей ми вимірюємо 20 типів поведінки друзів, 17 включені в запитання 10 та ще три (запитання 4, 5, 6) інтегровані у скринінг залежної поведінки і містять таку ж саме шкалу, як і РВР. Вимірювання здійснюється за допомогою 5позиційної шкали Лайкерта і включає такі варіанти відповіді на запитання: «Скільки серед твоїх друзів тих, що ...»: 1. Майже нікого; 2. Декілька; 3. Половина; 4. Більшість; 5. Майже всі. Бали присвоюються відповідно до номеру відповіді - від 1 до 5.

Кожен тип поведінки оцінюється окремо, але показники можливо об'єднати у 5 груп:

1. Дозвілля - субзапитання 1-6 (додаткове навчання, спорт, творчість та техніка, музика, комп'ютерні ігри, соціальні мережі).

2. Навчання - 7 (відмінники).

3. Субкультура - 9-11 («тусуються», екстремальний спорт, альтернативні субкультури).

4. Статевий розвиток - 12 (друзі однієї статі - цей показник виходить 3 протилежного, якщо друзів однієї з опитаним статі половина, то іншої статі теж половина).

5. Ненормативна поведінка - 8 (прогулюють школу), 13-17 (вигнані з уроків, викликають батьків, чинять вандалізм, крадуть в інших, крадуть у магазині).

6. Адиктивна поведінка - запитання в опитувальнику ULS 4 (тютюнопаління), 5 (вживання алкоголю) та 6 (вживання наркотиків).

\section{Булінг}

Для дітей:

IBS - Іллінойська Шкала Булінгу: шкільний варіант Запитання 20 в опитувальнику ULS для дітей (Додаток 4)

Посилання: Espelage, D. L. \& Holt, M. (2001). Bullying and victimization during early adolescence: Peer influences and psychosocial correlates. Journal of Emotional Abuse, 2, 123-142

Нами використано модифікацію IBS, розроблену в рамках проекту Second Step Bullying Prevention Unit (https://www.secondstep.org/bullying-prevention).

IBS - Illinoi Bully Scale: Student Version - Іллінойська шкала булінгу (шкільний варіант) є емпірично валідизованим опитувальником для самостійного заповнення, який широко використовується для вимірювання знущань і віктимізації в шкільному середовищі, починаючи з третього класу. Часовий інтервал, який покриває опитувальник, 30 днів, тому його можливо використовувати 3 метою моніторингу рівня булінгу протягом навчального року. Використаний нами варіант шкали $є$ шкільною версією оригінальної шкали, яка спрощує аналіз результатів. На відміну від оригінальної шкали, яка має 18 запитань, об’єднані у 3 субшкали: булінг (9 запитань), бійки (5 запитань) та віктимізація (4 запитання). Використана нами модифікація Іллінойської шкали булінгу поділяється на дві частини відповідно до ролі, яку виконує учень, - кривдника чи жертви:

1. Булінг (кривдник) - вимірює ступінь залучення учнів до знущань (запитання 1-9), об’єднує 8 запитань оригінальної шкали булінгу IBS та 1 запитання з шкали бійки IBS. Фізичне насильство та неконтрольована фізична агресія $\epsilon$ окремими категоріями і виходять за межі поняття булінгу, тому в цьому опитувальнику 3 шкали бійки використано лише «погрози вдарити або поранити іншого учня» (запитання 6). Крім того, в опитувальнику ULS вже $\epsilon$ шкала агресивної поведінки YSR та CBCL. 
2. Віктимізація (жертва) - вимірює ступінь, в який учні самі стали жертвами знущань (запитання 10-16). Повністю включає в себе 4 запитання оригінальної шкали віктимізації IBS та 3 додаткові показники, які розширюють діапазон діагностики поведінкових проявів булінгу.

\section{Інтерпретація результатів:}

Бали рахуються відповідно до варіантів відповіді:

- Ніколи - 0 балів

- 1-2 рази - 1 бал

- 3-4 рази - 2 бали

- 5-6 разів - 3 бали

- 7 та більше разів - 4 бали

Чим більше сумарний бал, тим вище рівень булінгу (максимально 36 балів) та віктимізації (максимально 28 балів). Норми за цим опитувальником не існує, він розрахований на періодичні заміри у навчальному закладі з метою порівняння результатів протягом навчального року або 3 іншим часовим інтервалом. Відомо, що рівень проявів булінгу підвищується протягом навчального року - від осені до весни - тому слід порівнювати ідентичні часові інтервали поміж собою (середина року 3 серединою наступного року або весна з весною наступного року), щоб сезонні зміни у вираженості цієї поведінки не впливали на отриманий результат моніторингу.

\section{Суйщидальність, самотність, тривожність та депресія}

\section{Для дітей:}

\section{ACSS-FAD - Шкала набутої здатності до самогубства та відсутності побоювання смерті} Запитання 25 в опитувальнику ULS для дітей (Додаток 4)

Посилання: Ribeiro, J. D., Witte, T. K., Van Orden, K. A., Selby, E. A., Gordon, K. H., Bender, T. W., \& Joiner, T. E., Jr. (2014). Fearlessness about death: The psychometric properties and construct validity of the revision to the Acquired Capability for Suicide Scale. Psychological Assessment, 26(1), 115-126. http://dx.doi.org/10.1037/a0034858

ACSS-FAD - Acquired Capability for Suicide Scale - Fearlessness About Death. (ACSS; Van Orden, Witte, Gordon, Bender, \& Joiner, 2008) Шкала набутої здатності до самогубства та відсутності побоювання смерті. Міжособистісна теорія суїциду стверджує, що суїцидальна поведінка настільки лякає, що для того, щоб людина здійснила суїцид, прагнення до самогубства має супроводжуватися здатністю до цього. Здатність до самогубства характеризується трьома конструктами: 1) відсутністю побоювань смерті, 2) підвищеною фізіологічною толерантністю до болю та 3) провокативними подіями. На початку шкала ACSS включала 20 запитань, що вимірювали вказані 3 конструкти, але пізніше шкалу модернізували відповідно до проведеного факторного аналізу і видалили запитання, які не відносяться до конструкту «придбаної здатності до самогубства» (провокуючі події та зайві запитання стосовно фізичної толерантності до болю). На наш погляд, блок запитань про провокуючі події слід включати в опитувальник ULS, як ми це робимо у першій хвилі дослідження.

Модернізована шала здатності до суїциду ACSS-FAD включає 7 запитань, які вимірюють відсутність побоювань смерті (6 запитань) та страх відчути біль (1 запитання). Дані досліджень демонструють конвергентну та дискримінантну валідність шкали у підлітків та серед стаціонарних психіатричних хворих.

Оригінальна методика ACSS-FAD складається з 7 показників:

У таблиці 8 наведено бали для кожної відповіді, кожне запитання оцінюється від 0 до 4 балів, загальний бал варіюється від 0 до 28 балів. У нормативній вибірковій сукупності середній бал коливався біля $2-\mathrm{x}$, а загальний бал коливався біля 17 , таким чином показники 18 балів та вище можливо розглядати як різний ступінь ризику.

Чим більший загальний бал, тим вищий рівень FAD - відсутності побоювання смерті. Цей фактор розглядається як основний діагностичний конструкт, тісно пов'язаний iз здатністю скоїти самогубство. Результати застосування ACSS-FAD у першій хвилі ULS та у 
студентському модулі ULS+, показують що у «групу ризику» самогубства входить та 13,6 \% дітей 11-12 років та чверть молоді 17-25 років (25\%).

Варто зазначити, що реальних масштабів поширення компонентів суїцидальної поведінки в Україні невідомо через вітчизняну традицію не задавати прямих запитань про суїцид. Така думка успадкована нами з радянської психологічної та психіатричної традиції. На відміну від цього підходу, західна традиція в психодіагностиці вже подолала це упередження і прямі запитання про суїцидальну поведінку сприймаються нормально. Але методика ACSS-FAD, яка нещодавно увійшла у діагностичну практику, є однією 3 небагатьох методик опосередкованого моніторингу суїцидальності, які спираються на вимір внутрішнього конструкту здатності до суїциду без прямих запитань про суїцидальні думки чи спроби скоїти суїцид.

Запитання оригінальної методики ACSS-FAD та оцінка відповідей у балах.

Уважно прочитай кожне питання і вкажи, наскільки воно відображає Тебе?

\begin{tabular}{|l|l|c|c|c|c|c|}
\hline & \multicolumn{1}{|c|}{$\begin{array}{c}\text { Обведи або закресли номер } \\
\text { обраної відповіді }\end{array}$} & $\begin{array}{c}\text { Зовсім } \\
\text { не про } \\
\text { мене }\end{array}$ & $\begin{array}{c}\text { Скоріше } \\
\text { не про } \\
\text { мене }\end{array}$ & $\begin{array}{c}\text { У чомусь } \\
\text { так, у } \\
\text { чомусь ні }\end{array}$ & $\begin{array}{c}\text { Скоріше } \\
\text { про мене }\end{array}$ & $\begin{array}{c}\text { Повністю } \\
\text { про мене }\end{array}$ \\
\hline 1 & $\begin{array}{l}\text { Той факт, що я помру, на мене не } \\
\text { впливає. }\end{array}$ & 0 & 1 & 2 & 3 & 4 \\
\hline 2 & Мене лякає біль під час смерті. & 4 & 3 & 2 & 1 & 0 \\
\hline 3 & Я дуже боюся вмерти. & 0 & 1 & 2 & 3 & 4 \\
\hline 4 & $\begin{array}{l}\text { Я не нервуюся, коли люди } \\
\text { говорять про смерть. }\end{array}$ & 0 & 1 & 2 & 3 & 4 \\
\hline 5 & $\begin{array}{l}\text { Перспектива власної смерті } \\
\text { викликає в мене тривогу. }\end{array}$ & 4 & 3 & 2 & 1 & 0 \\
\hline 6 & $\begin{array}{l}\text { Мене не турбує смерть, як кінець } \\
\text { Життя, у відомій мені формі. }\end{array}$ & 0 & 1 & 2 & 3 & 4 \\
\hline 7 & Я зовсім не боюся смерті. & 0 & 1 & 2 & 3 & 4 \\
\hline
\end{tabular}

NSDUH - прямі запитання щодо суӥцидальних проявів Національного опитування 3 вживання наркотиків та здоров'я

\section{Запитання 24 в опитувальнику ULS для дітей (Додаток 4)}

Суїцидальна поведінка носить латентний характер, про ії масштаби в Україні судять по статистиці завершених та незавершених спроб, але до цього людина проходить певний шлях який цілком можливо відслідкувати та оцінити здатність до скоєння самогубства. 3 цією метою до інструментарію дослідження нами було включено ряд прямих запитань NSDUH (National Survey on Drug Use and Health) - Національного опитування з вживання наркотиків та здоров'я (США), адаптованих нами в рамках студентського модуля Українського лонгітюдного дослідження (ULS+). В опитувальнику ULS першої хвилі модуль моніторингу суїцидальної поведінки скорочено до 3-х показників, які описують зовнішні фактори (провокуючі події) - суїцидальні думки у друзів, спілкування про суїцид та пропозиції скоїти суїцид (запитання 1-3), а у опитувальнику студентського та клінічного модулів ULS+ присутні усі прямі запитання:

1. Чи були у Твоїх друзів коли-небудь думки про те, щоб покінчити життя самогубством?

2. Чи спілкувався Ти з ким-небудь на теми, пов'язані з самогубством?

3. Чи пропонував Тобі хто-небудь скоїти самогубство?

Запитання студентського модуля ULS+:

4. Чи були у Вас думки про те, щоб покінчити життя самогубством?

5. Чи планували Ви колись, як покінчити життя самогубством?

6. Чи робили Ви колись спроби покінчити життя самогубством?

7. Чи $є$ у Вас члени родини або друзі, які намагалися покінчити життя самогубством але вижили?

8. Чи є у Вас члени родини або друзі, які покінчили життя самогубством? 
Оцінювання відбувається за кожним запитанням окремо, варіанти відповідей включають окрім прямих відповідей «Так» чи «Ні» можливість ухилення від прямої відповіді - відповідь «Не знаю».

Результати застосування прямих запитань NSDUH щодо суїцидальних проявів у першій хвилі ULS та студентському модулі ULS+ показують, що:

- $28,5 \%$ (17-25 років) та 21,3\% (11-12 років) повідомили, що у їхніх друзів були думки про те, щоб покінчити життя самогубством;

- 40,9\% (17-25 років) та 19,9\% (11-12 років) спілкувались 3 ким-небудь на теми, пов'язані з самогубством;

- до $2,1 \%$ (17-25 років) та $8,4 \%$ (11-12 років) надходили пропозиції скоїти самогубство і ще 2,6\% (17-25 років) та 4,9\% (11-12 років) в цьому не впевнені;

- у 25\% (17-25 років) були думки про те, щоб покінчити життя самогубством;

- $14 \%$ (17-25 років) планували як покінчити життя самогубством;

- $5 \%$ (17-25 років) робили спроби покінчити життя самогубством;

- у 9\% (17-25 років) є члени родини або друзі, які намагалися покінчити життя самогубством але вижили;

- у 7\% (17-25 років) є члени родини або друзі, які покінчили життя самогубством.

Звертає на себе увагу значно більша, у порівнянні з старшою віковою групою (17-25 років), розповсюдженість пропозицій скоїти самогубство серед дітей середнього шкільного віку (11-12 років), що потребує додаткового вивчення як шляхів та механізмів таких звернень, так і реалізації відповідних профілактичних втручань.

\section{UCLA Loneliness Scale - Шкала самотності та соціальної ізоляції Запитання 22 в опитувальнику ULS для дітей (Додаток 4)}

Посилання: Hughes, M. E., Waite, L. J., Hawkley, L. C., \& Cacioppo, J. T. (2004). A Short Scale for Measuring Loneliness in Large Surveys: Results From Two Population-Based Studies. Research on Aging, 26(6), 655-672. https://doi.org/10.1177/0164027504268574

The UCLA Three-Item Loneliness Scale. Шкала самотності, яка складається 3 3-х запитань (табл. 9), розроблена для самостійного заповнення, вимірює загальне відчуття самотності та соціальної ізоляції. Запропонований варіант шкали $\epsilon$ скороченою модифікацією Переглянутої Шкали самотності Каліфорнійського університету, яка складається з 20 запитань (Revised UCLA Loneliness Scale - Russell, D., Peplau, L.A., \& Cutrona, C.E. (1980). The revised UCLA Loneliness Scale: Concurrent and discriminant validity evidence. Journal of Personality and Social Psychology, 39, 472-480.).

Шкала дозволяє швидко оцінити суб'єктивне відчуття самотності та соціальної ізоляції. Дослідження показують достатню надійність та валідність цієї шкали при самостійному заповненні та при телефонному опитуванні, що може бути поширене і на методологію вебопитування у великих дослідженнях. Нормування для цілей індивідуальної психодіагностики не розроблено, але шкала показала високу ефективність у епідеміологічних та крос-культурних дослідженнях.

\section{Розрахунок балів за шкалою самотності}

Таблиця 9 Будь ласка вкажи, як часто Ти відчуваєш наступне ...

\begin{tabular}{|l|l|c|c|c|}
\hline & \multicolumn{1}{|c|}{} & Майже ніколи & Інколи & Часто \\
\hline 1 & Як часто Ти відчуваєш, що тобі бракує компанії? & 1 & 2 & 3 \\
\hline 2 & Як часто Ти відчуваєш себе покинутим (ою)? & 1 & 2 & 3 \\
\hline 3 & Як часто Ти відчуваєш себе ізольованим (ою) від інших? & 1 & 2 & 3 \\
\hline
\end{tabular}

\section{Інтерпретація результатів:}

На кожне запитання передбачено 3 варіанти відповіді, кожному з яких присвоюється від 1 до 3-х балів (див. табл. 9). Загальна сума балів за усіма запитаннями варіюється від 3-х до 9 балів. Вищі бали означають більше суб'єктивне відчуття самотності та соціальної ізоляції. 
Застосування шкали самотності та соціальної ізоляції UCLA Loneliness Scale у студентському та основному модулі ULS показало наступні результати:

- Підвищене відчуття самотності (7-9 балів) спостерігається у 14,4 \% молодих харків'ян 17-25 років та у $8,4 \%$ дітей $11-12$ років.

- Найвищі показники соціальної ізоляції (9 балів) спостерігаються у 4,5 \% молодих харків'ян 17-25 років та у 1,6 \% дітей 11-12 років.

Означені групи потребують поглибленої психодіагностики та втручання у разі необхідності.

PHQ-4 - Опитувальник здоров'я паціснта (4 запитання для виявлення депресії та тривожності)

Запитання 23 в опитувальнику ULS для дітей (Додаток 4)

Посилання: Kroenke, K., Spitzer, R. L., Williams, J. B. W., Löwe, B. (2009). An ultra-brief screening scale for anxiety and depression: the PHQ-4 Psychosomatics, 50, 613-621.

PHQ-4 - The Patient Health Questionnaire-4. Опитувальник здоров'я пацієнта (PHQ-4) містить 4 запитання, які оцінюються за 4-бальною шкалою Лікерта (табл. 10). Перші два питання взяті 3 «Шкали загального тривожного розладу-7» (GAD-7), а інші два питання - 3 «Опитувальника здоров'я пацієнта-8» (PHQ-8). PHQ-4 дуже короткий і точний інструмент для вимірювання депресії і тривожності.

\section{Розрахунок балів за шкалою PHQ-4}

Таблиця 10

Як часто впродовж останніх 2 тижнів Тебе турбували наступні речі?

\begin{tabular}{|l|l|c|c|c|c|}
\hline & $\begin{array}{c}\text { Жодного } \\
\text { разу }\end{array}$ & $\begin{array}{c}\text { Кілька } \\
\text { днів }\end{array}$ & $\begin{array}{c}\text { Більше } \\
\text { половини днів }\end{array}$ & $\begin{array}{c}\text { Майже } \\
\text { щодня }\end{array}$ \\
\hline 1 & $\begin{array}{l}\text { Дуже нервувався (лася), відчував (ла) надмірне } \\
\text { напруження, тривогу }\end{array}$ & 0 & 1 & 2 & 3 \\
\hline 2 & Був (ла) не в змозі припинити хвилювання & 0 & 1 & 2 & 3 \\
\hline 3 & $\begin{array}{l}\text { Нникло задоволення та інтерес до того, що } \\
\text { раніше було цікаво робити }\end{array}$ & 0 & 1 & 2 & 3 \\
\hline 4 & $\begin{array}{l}\text { Почувався пригніченим (ною), відчував (ла) } \\
\text { депресію, безнадійність }\end{array}$ & 0 & 1 & 2 & 3 \\
\hline
\end{tabular}

Інтерпретація результатів:

За кожний варіант відповіді передбачено від 0 до 3 балів (див. табл. 9). Загальний бал підраховується як сума балів за усі 4 запитання.

Загальний бал - експрес-оцінювання психічного стану пацієнта описує «рівень психологічного дистресу»:

- 0-2 нормальний (normal);

- 3-5 легкий (mild);

- 6-8 помірний (moderate);

- 9-12 тяжкий (severe).

Оцінювання тривожності - сума балів по 1 та 2 запитанню $\geq 3$ свідчить про наявність тривожного розладу.

Оцінювання депресії - сума балів по 3 та 4 запитанню $\geq 3$ свідчить про наявність депресивного стану.

Результати застосування опитувальника здоров'я пацієнта PHQ-4 показують позитивний скринінг на розлад психічного стану у наступних груп:

- Наявність психологічного дістресу різного ступеня у 37,4 \% молодих осіб 17-25 років та у 30,3 \% дітей 11-12 років.

- Наявність тривожного розладу спостерігається у 13,7 \% молодих осіб 17-25 років та у 12,1\% дітей 11-12 років.

- Наявність депресії спостерігається у 13,7 \% молодих осіб $17-25$ років та у 13,5 \% дітей 11-12 років. 
Означені групи потребують поглибленої психодіагностики та втручання у разі необхідності.

\section{Сон}

Для дітей:

PSQ - Піттсбурзький Індекс Якості Сну

Запитання 21 в опитувальнику ULS для дітей (Додаток 4)

Посилання: Buysse, Daniel J.; Reynolds, Charles F.; Monk, Timothy H.; Berman, Susan R.; Kupfer, David J. (May 1989). "The Pittsburgh sleep quality index: A new instrument for psychiatric practice and research". Psychiatry Research. 28 (2): 193-213. doi:10.1016/01651781(89)90047-4. PMID 274877

PSQ - The Pittsburgh Sleep Quality Index. Піттсбурзький індекс якості сну опитувальник для самостійного заповнення, який оцінює якість сну і його порушення протягом останнього місяця. Опитувальник складається 3 2-х частин: перша - для самостійного заповнення містить 19 запитань i підлягає кількісній обробці завдяки можливості розрахунку загального балу; друга - містить 5 запитань, які стосуються партнера по ліжку, якщо такий $\epsilon$, i не підлягає кількісній обробці (бали за цією частиною не рахуються). В опитувальнику ULS ми використовуємо лише першу формалізовану частину опитувальника, яка сфокусована на звичках сну за останні 30 днів. Дев'ятнадцять запитань згруповані у сім «компонентних» шкал: суб'єктивна якість сну, затримка сну, тривалість сну, звичну продуктивність сну, порушення сну, використання снодійних препаратів і денна дисфункціональність. Сума балів за цими сімома шкалами дає загальну оцінку якості сну.

До переліку причин порушення сну (субзапитання 5-15) нами було добавлено додаткову причину порушення сну, яка $\epsilon$ досить розповсюдженою серед українських підлітків - субзапитання 14 «Розмовляв чи ходив під час сну, а потім не згадував про це».

Клінічні та клініко-діагностичні властивості PSQI показують високу внутрішню однорідність та узгодженість елементів шкали, iii ретестову надійність та валідність. Глобальний показник PSQI> 5 дає діагностичну чутливість у 89,6\% і специфічність 86,5\% (каппа $=0,75, \mathrm{p}<0,001)$ для розрізнення хорошої і поганої якості сну. Клініко-діагностичні властивості PSQI вказують на іï корисність як у психіатричній клінічній практиці, так і в дослідницькій діяльності.

\section{Підрахунок балів}

Оцінки за компонентними шкалами рахуються від 0 до 3 балів, оцінка по загальній шкалі якості сну складається з суми оцінок за 7 компонентними шкалами і варіюється від 0 немає порушень сну до 21 - серйозні порушення сну.

\section{Компонент 1. Суб'сктивна якість сну.}

Бал визначається згідно з відповідями на субзапитання 19. «За останні 30 днів, як би Ти оцінив якість свого сну загалом?»

- Дуже добре $=0$ балів

- Скоріше добре $=1$ бал

- Скоріше погано = 2 бали

- Дуже погано = 3 бали

Компонент 2. Затримка сну.

Бал по Компоненту 2 розраховується залежно від суми балів по субзапитанням 2 та 5.

Крок 1. Визначити бал за субзапитанням 2. «Як швидко (в хвилинах) зазвичай Ти засинав щоночі?» Приблизна кількість хвилин:

- $\leq 15$ хв. $=0$ балів

- 16-30 хв. $=1$ бал

- 31-60 хв. $=2$ бали

- $>60$ хв. $=3$ бали

Крок 2. Визначити бал за субзапитанням 5. «Наскільки часто з Тобою відбувались наступні речі під час сну за останні 30 днів? Не міг заснути впродовж 30 хвилин.» 
- Жодного разу протягом минулого місяця = 0 балів

- Менше одного разу на тиждень = 1 бал

- Один або два рази на тиждень = 2 бали

- Три або більше разів на тиждень $=3$ бали

Крок 3. Розрахувати бал по Компоненту 2 залежно від суми балів по субзапитанням 2 та 5:

- $0=0$ балів

- $1-2=1$ бал

- $3-4=2$ бали

- $5-6=3$ бали

\section{Компонент 3. Тривалість сну.}

Бал визначається згідно з відповідями на субзапитання 4. «Скільки годин Ти реально спав вночі? (Це може відрізнятись від кількості годин, які Ти проводив у ліжку)». Приблизна кількість годин сну за ніч:

- $\quad>7$ годин $=0$ балів

- $6-7$ годин $=1$ бал

- $5-6$ годин $=2$ бали

- $\quad<5$ годин $=3$ бали

Компонент 4. Звична продуктивність сну.

Розраховується у відсотках наступним чином:

Крок 1. Визначити «кількість годин сну» - відповідь на субзапитання 4. «Скільки годин Ти реально спав вночі? Приблизна кількість годин сну за ніч: ".

Крок 2. Визначити «кількість годин проведених у ліжку» - підрахувати проміжок часу між часом позначеним у відповіді на субзапитання 1. «О котрій годині Ти зазвичай лягав ввечері спати? Вкажи час відходу до сну: » та відповіді на субзапитання 3. «Коли Ти зазвичай прокидався вранці? Звичайний час підйому: $\gg$.

Крок 3. Розрахувати відсоток звичної продуктивності сну за формулою:

«кількість годин сну» / «кількість годин проведених у ліжку» х 100

Крок 4. Розрахувати бали по компоненту 4 відповідно до відсотку звичної продуктивності сну:

- $>85 \%=0$ балів

- $75 \%-84 \%=1$ бал

- $65 \%-74 \%=2$ бали

- $<65 \%=3$ бали

Компонент 5. Порушення сну.

Бал по Компоненту 5 розраховується залежно від суми балів за субзапитаннями 6-15:

Крок 1. Визначити суму балів за субзапитаннями 6-15 (табл. 11)

Крок 2. Розрахувати бали по компоненту 5 відповідно до сумарного балу за субзапитаннями 6-15:

- $0=0$ балів

- $1-10=1$ бал

- $11-20=2$ бали

- $21-30=3$ бали

Компонент 6. Використання снодійних препаратів.

Бал визначається згідно з відповідями на субзапитання 16. «Як часто за останні 30 днів Ти приймав снодійні препарати?»

- Жодного разу протягом минулого місяця = 0 балів

- Менше одного разу на тиждень = 1 бал

- Один або два рази на тиждень = 2 бали

- Три або більше разів на тиждень $=3$ бали 


\section{Компонент 7. Денна дисфункціональність.}

Бал по Компоненту 7 розраховується залежно від суми балів по субзапитанням 17 та 18.

Крок 1. Визначити бал за субзапитаннями 17. «Як часто за останні 30 днів Ти почувався сонним (невиспаним) протягом дня?» та 18. «Чи було за останні 30 днів достатньо у тебе сил, щоб доводити все, що робиш, до кінця?».

- Жодного разу протягом минулого місяця = 0 балів

- Менше одного разу на тиждень $=1$ бал

- Один або два рази на тиждень = 2 бали

- Три або більше разів на тиждень $=3$ бали

- $0=0$ балів

- $1-2=1$ бал

- $3-4=2$ бали

- 5-6=3 бали

Таблиця 11

Розрахунок балів за запитаннями Q6-15 шкали PSQ

Наскільки часто з Тобою відбувались наступні речі під час сну за останні 30 днів?

\begin{tabular}{|c|c|c|c|c|c|}
\hline & $\begin{array}{c}\text { Обведи або закресли номер обраної } \\
\text { відповідi: }\end{array}$ & $\begin{array}{c}\text { Жодного разу } \\
\text { протягом } \\
\text { минулого } \\
\text { місяця }\end{array}$ & $\begin{array}{c}\text { Менше } \\
\text { одного разу } \\
\text { на тиждень }\end{array}$ & $\begin{array}{c}\text { Один або два } \\
\text { рази на } \\
\text { тиждень }\end{array}$ & $\begin{array}{c}\text { Три або } \\
\text { більше } \\
\text { разів на } \\
\text { тиждень } \\
\end{array}$ \\
\hline 6 & $\begin{array}{l}\text { Прокидався посеред ночі або дуже } \\
\text { рано }\end{array}$ & 0 & 1 & 2 & 3 \\
\hline 7 & $\begin{array}{l}\text { Прокидався через потребу сходити } \\
\text { до туалету }\end{array}$ & 0 & 1 & 2 & 3 \\
\hline 8 & Було важко дихати & 0 & 1 & 2 & 3 \\
\hline 9 & Гучно кашляв або хропів & 0 & 1 & 2 & 3 \\
\hline 10 & Відчував, що було занадто холодно & 0 & 1 & 2 & 3 \\
\hline 11 & $\begin{array}{l}\text { Відчував, що було занадто } \\
\text { спекотно }\end{array}$ & 0 & 1 & 2 & 3 \\
\hline 12 & Снилися погані сни & 0 & 1 & 2 & 3 \\
\hline 13 & Турбував біль & 0 & 1 & 2 & 3 \\
\hline 14 & $\begin{array}{l}\text { Розмовляв чи ходив під час сну, а } \\
\text { потім не згадував про це* }\end{array}$ & 0 & 1 & 2 & 3 \\
\hline 15 & $\begin{array}{l}\text { Інші незручності (допищи, щуо } \\
\text { саме): }\end{array}$ & 0 & 1 & 2 & 3 \\
\hline
\end{tabular}

*Примітка: в оригінальній методиці субзапитання 14 відсутне $i$ сумарний бал за компонентом 5 розраховується відповідно до 9 субзапитань: $0=0$ балів; $1-9=1$ бал; 10-18=2 бали; $19-27=3$ бали.

\section{Загальне здоров'я}

Для дітей:

GSE - Шкала загальної самоефективності

Запитання 17 в опитувальнику ULS для дітей (Додаток 4)

Посилання: Schwarzer, R., \& Jerusalem, M. (1995). Generalized Self-Efficacy scale. In J. Weinman, S. Wright, \& M. Johnston, Measures in health psychology: A user's portfolio. Causal and control beliefs (pp. 35-37). Windsor, UK: NFER-NELSON.

http://userpage.fu-berlin.de/health/engscal.htm

GSE - The General Self-Efficacy scale (Schwarzer \& Jerusalem, 1995). Шкала загальної самоефективності була створена для оцінки загального сприйняття самоефективності 3 метою передбачення успішності подолання життєвих перешкод, а також адаптації після переживання стресових подій. Шкала спрямована на оцінку здатності виконувати нові або складні завдання, аби впоратися з труднощами в різних сферах функціонування людини. 
Самоефективність - конструкт, що описує постановку цілей, наполегливість у подоланні перешкод та відновлення після невдач, їі можна розглядати як позитивний ресурсний фактор особистісної стійкості. Шкала містить 10 запитань, які оцінюються за допомогою 4-позиційної шкали Лікерта. Високі бали за цією шкалою корелюють 3 позитивним емоційним фоном, оптимізмом, задоволеністю діяльністю та негативно корелюють 3 депресією, стресом, скаргами на здоров'я, вигоранням та тривожністю.

Інтерпретація результатів:

10 запитань шкали мають 4 варіанти відповіді. Кожному варіанту відповідає оцінка у балах:

- Зовсім невірно = 1 бал

- Трохи вірно = 2 бали

- У середньому вірно $=3$ бали

- Повністю вірно = 4 бали

Загальна оцінка у балах є сумою балів по кожному запитанню. Загальна оцінка варіює від 10 до 40 балів. Чим більші оцінки - тим вищою є загальна самоефективність.

\section{AHP-SF - Шкала оцінювання поведінки 3 підтримки здоров'я (скорочений варіант для підлітків) \\ Запитання 19 в опитувальнику ULS для дітей (Додаток 4)}

Посилання: Chen, M.Y., Wang, E.K., Yang, R.J., et al. (2003). Adolescent health promotion scale: development and psychometric testing. Public Health Nursing Research, 13 (3), 235-243. Chen et al.: Development and validation of the short-form adolescent health promotion scale. BMC Public Health 2014 14:1106. doi:10.1186/1471-2458-14-1106

Підтримка здоров'я - Health Promotion - $\epsilon$ комплексним концептом, який добре описаний в літературі та використовується такими міжнародними організаціями як ВО3 (World health Organization, WHO: Health Promotion; 2014 http:/www.who.int/topics/health_promotion/en/) та Центр по контролю за захворюваннями (Chronic Disease Prevention and Health Promotion: Chronic Diseases and Health Promotion; 2014. http://www.cdc.gov/chronicdisease/overview/index.htm\#sec2).

AHP-SF - Short Form Adolescent Health Promotion scale. Скорочений варіант для підлітків Шкали оцінювання поведінки з підтримки здоров'я, яка складається з 21 запитання, які згруповані у шість субшкал: харчування (3 запитання), соціальна підтримка (4 запитання), відповідальність за підтримку здоров'я (4 запитання), задоволеність життям (4 запитання), фізичні вправи (3 запитання) та управління стресом (3 запитання). Оцінка здійснюється за допомогою 5-позиційної шкали Лікерта. Добрі психометричні властивості шкали підтверджені міжнародними крос-культурними дослідженнями. Адаптація шкали АНР-40, яка містить 40 запитань, для підлітків була здійснена міжнародним дослідницьким колективом (Chen, Lai, Chen, \& Gaete, 2014).

\section{Інтерпретація результатів:}

Шкала AHP-SF включає 6 субшкал, кожна 3 яких оцінюється від 1 до 5 балів за орієнтовним відсотком частоти проявлення поведінки у житті дитини. Загальний бал коливається від 6 до 84. Можливо використовувати як загальний бал, так і бали за окремими шкалами, оскільки результати факторного аналізу показують їх достатню специфічність.

Варіанти відповіді:

- Ніколи (до 10\%) = 1 бал

- Рідко $(30 \%)=2$ бали

- У половині випадків $(50 \%)=3$ бали

- Часто $(70 \%)=4$ бали

- Постійно $(90 \%+)=5$ балів

Субшкали:

1. Харчування (Nutrition) - субзапитання 1-3;

2. Соціальна підтримка (social support) - субзапитання 4-7;

3. Відповідальність за підтримку здоров'я (health responsibility) - субзапитання 8-11;

4. Задоволеність життям (life appreciation) - субзапитання 12-15; 
5. Фізичні вправи (exercise) - субзапитання 16-18;

6. Управління стресом (stress management) - субзапитання 19-21.

\section{Food Security Scale - Шкала безпечності харчування (украӥнська версія)}

\section{Запитання 26 в опитувальнику ULS для дітей (Додаток 4)}

Food Security Scale - Шкала безпечності харчування вимірює частоту вживання 18 типів найбільш розповсюджених в Україні продуктів харчування. Вимірювання здійснюється за допомогою 5-позиційної шкали Лікерта, від «кожен день» до «не вживав ніколи» (кодування реверсивне - від 4 до 0).

Інтерпретація: специфічних норм для цієї шкали немає, інтерпретація результатів здійснюється по кожному типу продуктів окремо, можливо здійснювати групування продуктів у більш широкі класи (мучні, м'ясні, риба, молочні, овочі, фрукти, «фастфуд», вулична їжа тощо).

\section{Варіанти відповіді:}

- Кожен день $=4$

- Два-три рази на тиждень = 3

- Один раз на тиждень $=2$

- Один раз на місяць = 1

- Не вживав (-ла) $=0$

Перелік типів продуктів харчування:

1. Цукерки

2. Тістечка, здобні вироби

3. М'ясо

4. Варені ковбаси, сосиски, сарделі

5. Копчені ковбаси

6. Риба

7. Копчена риба

8. Молоко

9. Сир

10. Йогурт, кисломолочні продукти

11. Морозиво

12. Свіжі овочі

13. Свіжі фрукти

14. Майонез, соуси, кетчуп

15. «Фастфуд»

16. Вулична їжа (шаурма, хотдоги, пиріжки ...)

17. Чіпси, сухарики

18. Продукти швидкого приготування («мівіна»)

Для дітей та батьків:

ВМI - Індекс маси тіла

Запитання 4 та 5 в опитувальнику ULS для дітей (Додаток 4)

Запитання 7 та 8 в опитувальнику ULS для батьків (Додаток 3)

Посилання: The WHO Global Database on Body Mass Index http://apps.who.int/bmi/index.jsp?introPage=intro_3.html

BMI (body mass index) - Індекс маси тіла (IMT) - це відношення ваги людини до іiі зросту (в квадраті). ІМТ вважається оптимальним уніфікованим показником для оцінки розмірів тіла (ваги та зросту), які дозволяють оцінити широкий діапазон ризиків для здоров'я. Показники IMT в межах норми свідчать про низький ризик серцево-судинних захворювань, діабету та інших хронічних захворювань. IMT непрямо показує, чи $\epsilon$ маса людини недостатньою, нормальною або надмірною (ожиріння). У рамках класів IMТ можуть бути підкласи - наприклад, нестача маси може бути «помірною», «середньою» та «важкою». 
Розрахунок: індекс маси тіла розраховується шляхом ділення маси тіла (у кілограмах) на квадрат росту (у метрах).

IMT = маса тіла (у кілограмах) / квадрат росту (у метрах) $170 \mathrm{~cm}$ :

Наприклад: розрахунок індексу маси тіла для людини, яка важить 65 кг при зрості

$$
I M T=65 / 1,7 \times 1,7=22,5
$$

\section{Нормування:}

Показники індексу маси тіла у дорослих достатньо стабільні, але для дітей та підлітків, які продовжують рости, неможливо визначити певні сталі показники IMT, що відповідають нормі для всіх вікових груп та для обох статевих груп. Тому використовуються таблиці, в яких нормальні межі IMT зазначено для кожного віку (табл. 12). Для індивідуального розрахунку можливо скористатись онлайн-калькулятором, які є широко розповсюдженими в мережі Інтернет, та включають змінну віку для коректного розрахунку IMT дитини.

Таблиця 12

\section{Приклади нормування IMT в залежності від статі та віку}

\begin{tabular}{|c|c|}
\hline \multicolumn{2}{|c|}{ Норми ІМТ для дорослих без урахування статі } \\
\hline Показник IMT, кг/м2 & Ознака \\
\hline Менше 18.5 & свідчить про недостатню вагу \\
\hline $18,5-24,9$ & еквівалент нормальної маси тіла \\
\hline $25,0-29,9$ & вказує на наявність зайвої ваги \\
\hline Понад 30 & с ознакою ожиріння \\
\hline
\end{tabular}

\begin{tabular}{|c|c|c|}
\hline \multicolumn{3}{|c|}{ Норми ІМТ для дорослих з урахуванням статі } \\
\hline IМТ жінок & ІМТ чоловіків & Результат \\
\hline менше 19 & менше 20 & недостатня вага \\
\hline $19-24$ & $20-25$ & нормальна вага \\
\hline $24-30$ & $25-30$ & невеликий надлишок ваги \\
\hline $30-40$ & $30-40$ & зайва вага \\
\hline вище 40 & вище 40 & сильне ожиріння \\
\hline
\end{tabular}

\section{Ocобистість}

Для дітей та батьків:

BFI-10 - П'ятифакторний опитувальник особистості «Велика П'ятірка» Запитання 18 в опитувальнику ULS для дітей (Додаток 4)

(Методика першої хвилі, не використовуються у другій хвилі ULS для батьків, але присутня у додаткових модулях $(L S+)$

Посилання: Rammstedt, В. \& John, O.P. (2007). Measuring personality in one minute or less: A 10-item short version of the Big Five Inventory in English and German. Journal of Research in Personality, 41, 203-212.

BFI-10 - Скорочений варіант П'ятифакторного опитувальника особистості «Велика П'ятірка» містить 10 запитань, по 2 запитання на кожний особистісний фактор (табл. 12). Розроблений для експрес-діагностики особистості. BFI-10 має психометричні властивості, які можна порівняти з повним BFI-44 (44 запитаня) та NEO-PI-R (60 запитань). Валідизація використаної нами у опитувальнику ULS методики BFI-10 проводилась за допомогою широко розповсюдженої у пострадянському просторі модифікації П'ятифакторного опитувальника особистості на 75 запитань, здійсненої А.Б. Хромовим (Хромов А.Б. Пятифакторный опросник личности: Учебно-методическое пособие Курган: Изд-во Курганского гос. университета, 2000. - 23 с.). Валідизація була здійснена шляхом паралельного заповнення П'ятифакторного опитувальника особистості на 75 запитань та опитувальника BFI-10 у рамках дослідження «Молодь та наркотики», N=3000 опитування віч-на-віч та $\mathrm{N}=400$ веб-опитування. 
Посилання: Сердюк О. О. Молодь та наркотики - 2021 : результати моніторингу залежної поведінки серед молоді м. Харків 1995-2020 років та студентського модуля Українського лонгітюдного дослідження (ULS+): [монографія] / Сердюк О. О., Бурлака В. В., Даниленко Г. М., Бобро Н. В., Базима Б.О., Щербакова І. В. ; МВС України, Харків. нац. ун-т внутр. справ. - Харків : ХНУВС, 2021. - 92 с. https://doi.org/10.32631/dr2021

Велика п'ятірка - діспозиційна модель особистості людини (від англ. Disposition схильність). Модель базується на класичних дослідженнях Г. Олпорта, Г. Айзенка i Р. Кеттела, які вважали, що особистість характеризує міру індивідуальних відмінностей людини в ступені і формі адаптації до соціального середовища з урахуванням біологічних властивостей індивіда.

Грунтуючись на результатах порівняння середніх значень факторів «Великої п'ятірки» у масиві ULS+ серед осіб які вживали та не вживали наркотики було встановлено, що між ними існує статистично достовірні відмінності. Найбільшу діагностичну значущість має фактор «Свідомість» (Consciousness), який менш виражений серед споживачів наркотиків. Відмінностей не було виявлено лише по фактору «Екстраверсія» (Extraversion). В цілому, грунтуючись на особистісних характеристиках молодих осіб 17-25 років, які зізналися у вживанні наркотиків, їх можливо описати, як менш свідомих (відповідальних), більш конфліктних (недоброзичливих), більш нейротічних, але також i більш креативних i схильних до експериментування і отримання нового досвіду.

Інтерпретація результатів:

П'ятифакторна модель передбачає, що особистість людини включає в себе п'ять загальних і відносно незалежних рис (диспозицій), які в опитувальнику згруповані у 5 шкал:

1. Нейротизм (neuroticism, N), субзапитання $4 \mathrm{R}$ та 9;

2. Екстраверсія (extraversion, E), субзапитання $1 \mathrm{R}$ та 6;

3. Відкритість досвіду (openness to experience, O), субзапитання $5 \mathrm{R}$ та 10;

4. Згода (agreebleness, A), здатність прийти до згоди, субзапитання 2 та 7 R;

5. Свідомість (conscientiousness, C), усвідомленість, субзапитання $3 \mathrm{R}$ та 8;

( $R$ означає реверсивне оцінювання в балах)

Оцінювання відбувається за кожною шкалою окремо шляхом побудови особистісного профілю (NEOAC), вираженість особистісних факторів варіюється від 2 до 10 балів (табл. 13).

Таблиця 13

Опитувальник BFI-10 (шкали та їх оцінка у балах)

\begin{tabular}{|c|c|c|c|c|c|c|c|}
\hline & $\begin{array}{c}\text { Про мене можна сказати, що я ... } \\
\text { Обведи або закресли номер обраної відповідi: }\end{array}$ & 党 $\frac{0}{2}$ & 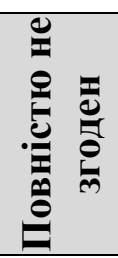 & 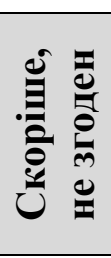 & 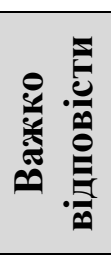 & 送 & 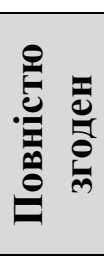 \\
\hline 1 & ... замкнутий & $\mathbf{E}$ & 5 & 4 & 3 & 2 & 1 \\
\hline 2 & ... зазвичай довіряю іншим & $\mathbf{A}$ & 1 & 2 & 3 & 4 & 5 \\
\hline 3 & ... дещо ледачий & $\mathbf{C}$ & 5 & 4 & 3 & 2 & 1 \\
\hline 4 & $\begin{array}{l}\text {.. добре справляюся з напруженими } \\
\text { ситуаціями }\end{array}$ & $\mathbf{N}$ & 5 & 4 & 3 & 2 & 1 \\
\hline 5 & ... схильний до занять творчістю & $\mathbf{O}$ & 5 & 4 & 3 & 2 & 1 \\
\hline 6 & $\begin{array}{c}\text {... без особливих зусиль знайомлюся і } \\
\text { встановлюю контакти з людьми }\end{array}$ & $\mathbf{E}$ & 1 & 2 & 3 & 4 & 5 \\
\hline 7 & ... легко помічаю недоліки інших людей & A & 5 & 4 & 3 & 2 & 1 \\
\hline 8 & ... роблю свою роботу ретельно і до кінця & $\mathbf{C}$ & 1 & 2 & 3 & 4 & 5 \\
\hline 9 & ... швидко починаю нервувати & $\mathbf{N}$ & 1 & 2 & 3 & 4 & 5 \\
\hline 10 & ... можу придумати щось нове & $\mathbf{O}$ & 1 & 2 & 3 & 4 & 5 \\
\hline
\end{tabular}


Діагностика ПТСР (посттравматичного стресового розладу):

(Методики першої хвилі, які не використовуються у другій хвилі ULS, але присутні $у$ додаткових модулях $U L S+)$

\section{LEC - Контрольний список травматичних подій життя}

Посилання: Gray, M., Litz, B., Hsu, J., \& Lombardo, T. (2004). Psychometric properties of the Life Events Checklist. Assessment, 11, 330-341. doi: 10.1177/1073191104269954 PILOTS ID: $26825 \mathrm{https}: / /$ www.ptsd.va.gov/professional/articles/article-pdf/id26825.pdf

LEC - Life Events Questionnaire. - Контрольний список травматичних подій життя перелік травматичних подій, необхідний елемент діагностики ПТСР, оскільки для постановки відповідного діагнозу у DSM, згідно з критерієм А для PTSD, необхідно «чітко визначити травмуючу подію». Нами внесено незначні модифікації в LEC для України стандартне запитання «участь у бойових діях» розширено до 3-х типів подій, пов'язаних 3 військовими діями (субзапитання 11, 12, 13).

Список вивчає досвід 18 типів травматичних подій протягом життя, 19 додаткове запитання надає можливість вказати «свій варіант» травматичної події. Інструмент був розроблений Національним центром ПТСР департаменту у справах ветеранів CША (U.S. Department of Veterans Affairs National Center for PTSD). Він ретельно перевірений у дослідженнях 3 різними соціально-демографічними групами, продемонстрував високі психометричні властивості і рекомендований для використання як 3 ветеранами, так i 3 цивільними особами.

\section{Варіанти відповідей LEC:}

1. Відбувалось зі мною

2. Був свідком

3. Чув про такий випадок

4. Невпевнений

5. Не стосується мене ніяк

Інтерпретація результатів:

Список не має кількісної інтерпретації або стандартизованого розрахунку балів. Для застосування Контрольного списку симптомів Посттравматичного стресового розладу (PCLC - PTSD CheckList) необхідно чітко встановити травмуючу подію, яка заподіяла стресовий розлад, згідно з критерієм А для ПТСP у DSM. Якщо така подія не встановлена діагностувати ПТСР неможливо. Щоб перейти до діагностики симптомів ПТСР у запитанні 34 опитувальника ULS для батьків, необхідно, щоб було позначено щонайменше 1 позицію із Контрольного списку травматичних подій життя. Це вимога DSM.

\section{PCL-C - Контрольний список симптомів Посттравматичного стресового розладу}

Посилання: Blanchard, E. B., Jones-Alexander, J., Buckley, T. С., \& Forneris, C. А. (1996). Psychometric properties of the PTSD checklist (PCL). Behavioral Research \& Therapy, 34, 669-673. https://www.ptsd.va.gov/professional/assessment/adult-sr/ptsd-checklist.asp

PCL-C - PTSD CheckList - Civilian Version. Контрольний список симптомів Посттравматичного стресового розладу - цивільна версія. PCL $є$ стандартизованою шкалою самооцінки ПТСР, опитувальник для самостійного заповнення, включає 17 запитань, які відповідають ключовим симптомам ПТСР згідно 3 діагностичними критеріями DSM-IV. Існують дві версії: PCL-M для військовослужбовців (military) та PCL-C для цивільних (civilian), яка підходить для будь-яких травматичних подій. Використовується разом 3 опитувальниками, що визначають конкретний тип події, що викликала симптоми ПТСР (LEC). Часові рамки для симптомів можливо змінювати залежно від цілей дослідження.

\section{Варіанти відповіді LEC:}

1. Зовсім ні

2. Трохи

3. Помірно

4. Доволі сильно

5. Дуже сильно 


\section{Інтерпретація результатів:}

Опитувальник містить 17 запитань, що відповідають діагностичним критеріям ПТСР за DSM-IV. Для кожного симптому передбачено 5 варіантів відповіді, які оцінюються від 1 до 5 балів. Загальний бал дорівнює сумі балів по кожному запитанню.

Можливо використовувати 2 шляхи інтерпретації результатів.

1) Інтерпретація за загальним балом: чим вищий загальний бал - тим серйознішим $\epsilon$ прояв ПТСР. Така інтерпретація здійснюється для наукових цілей та для моніторингу клінічних змін при лікуванні (повторне тестування).

Дослідження діагностичних властивостей PCL-C для DSM-IV при повторному тестуванні свідчать про те, що зміна загальної оцінки у 5-10 балів $\epsilon$ надійною (тобто зміна відбувається не через випадковість), а зміна у 10-20 балів є клінічно значущою. Тому рекомендовано використовувати 5 балів як мінімальний поріг для визначення того, чи відповіла людина на лікування, і 10 балів як мінімальний поріг для визначення того, чи $\epsilon$ поліпшення іiї стану клінічно значущим.

2) Інтерпретація результатів за критеріями DSM-IV: у цьому разі оцінюється кожне запитання окремо. Оцінка у 1-2 бали (вираженість симптому нижче помірної) означає доклінічний прояв симптому (non-symptomatic). Оцінка у 3-5 балів (вираженість симптому вище помірної) означає клінічний прояв симптому (symptomatic).

ПTCP за DSM-IV має 4 діагностичних критерії:

Критерій A: А1. Людина пережила, стала свідком або зіштовхнулася 3 подією чи подіями, що передбачали фактичну смерть, або загрозу життю чи серйозну травму, або загрозу фізичній цілісності особистості чи інших людей. А2. Реакція людини включала сильний страх, безпорадність або жах. Травмуюча подія повинна бути чітко визначена. Здійснюється за допомогою Контрольного списку травматичних подій життя - LEC (у попередньому запитанні).

Критерій В: Запитання 1-5. Щонайменше 1 відповідь повинна мати клінічну вираженість (3-5 балів). Травматична подія постійно переживається одним (або декількома) 3 5 визначених способів (кожне запитання є діагностичним критерієм DSM-IV).

Критерій C: Запитання 6-12. Щонайменше 3 відповіді повинні мати клінічну вираженість (3-5 балів). Постійне уникнення стимулів, пов'язаних з травмою, і зменшення загальної чутливості (якого не було перед травмою), на що вказують три (або більше) 3 наведених 7 ознак (кожне запитання є діагностичним критерієм DSM-IV).

Критерій D: Запитання 13-17. Щонайменше 2 відповіді повинні мати клінічну вираженість (3-5 балів). Стійкі симптоми підвищеного збудження (відсутні перед травмою), на що вказують дві (або більше) 3 наведених 5 ознак (кожне запитання є діагностичним критерієм DSM-IV).

\section{Додаткові критерії:}

Критерій E: Тривалість порушення (симптоми в критеріях B, C та D) становить понад 1 місяць. Відповідно до цього критерію запитання сформульовано з фокусом на подіях останнього місяця - «Позначте наскільки Вас хвилювали перелічені проблеми впродовж минулого місяця».

Критерій F: Порушення спричиняє клінічно значущі проблеми або погіршення в соціальних, професійних та інших важливих сферах функціонування. Цей загальний критерій означає, що виявлені в опитувальнику симптоми повинні чинити шкідливий вплив на життя людини. Якщо вони ніяк не впливають на життя та соціальне функціонування людини - діагноз ПТСР не повинен встановлюватись. 


\section{Бланк опитувальника LEC - Контрольний список травматичних подій життя}

Нижче перерахований перелік травмуючих або стресових випадків, які іноді трапляються з людьми. Чи відбувались з Вами подібні випадки або залишили слід у Вашому житті? Зробіть відмітку у кожному рядку щодо певної події.

Питання стосуються всього Вашого життя - як дитячого, так і дорослого.

Оберіть тільки один варіант відповіді. Якщо подія відбувалась з Вами одного разу та Ви були ї свідком іншого разу, оберіть варіант «Відбувалось зі мною».

\begin{tabular}{|c|c|c|c|c|c|}
\hline & $\begin{array}{l}\text { Відбувалось } \\
\text { зі мною }\end{array}$ & $\begin{array}{c}\text { Був } \\
\text { свідком }\end{array}$ & $\begin{array}{l}\text { Чув про } \\
\text { такий } \\
\text { випадок }\end{array}$ & $\begin{array}{c}\text { Не } \\
\text { впевне- } \\
\text { ний }\end{array}$ & $\begin{array}{c}\text { Не } \\
\text { стосусться } \\
\text { мене ніяк } \\
\end{array}$ \\
\hline $\begin{array}{l}\text { Стихійні лиха (наприклад, повінь, ураган, } \\
\text { землетрус) }\end{array}$ & 1 & 2 & 3 & 4 & 5 \\
\hline 2. Пожежа або вибух & 1 & 2 & 3 & 4 & 5 \\
\hline $\begin{array}{l}\text { 3ранспортна аварія (автомобільна, човна, } \\
\text { потягу, авіакатастрофа) }\end{array}$ & 1 & 2 & 3 & 4 & 5 \\
\hline $\begin{array}{l}\text { Серйозні пригоди/аварії на роботі, вдома } \\
\text { або під час відпочинку }\end{array}$ & 1 & 2 & 3 & 4 & 5 \\
\hline $\begin{array}{l}\text { В. Вплив токсичної речовини (небезпечної } \\
\text { хімічної речовини, газу, випромінювання) }\end{array}$ & 1 & 2 & 3 & 4 & 5 \\
\hline 6. Фізичний напад (побиття) & 1 & 2 & 3 & 4 & 5 \\
\hline $\begin{array}{l}\text { 3бройний напад (стрільба, погроза ножем, } \\
\text { пістолетом, бомбою) }\end{array}$ & 1 & 2 & 3 & 4 & 5 \\
\hline $\begin{array}{l}\text { Сексуальне насильство (згвалтування або } \\
\text { спроба згвалтування, будь-який тип } \\
\text { статевого акту під загрозою заподіяння } \\
\text { шкоди або насильницьким шляхом) }\end{array}$ & 1 & 2 & 3 & 4 & 5 \\
\hline $\begin{array}{l}\text { 9. Інший небажаний або неприємний } \\
\text { сексуальний досвід }\end{array}$ & 1 & 2 & 3 & 4 & 5 \\
\hline 10. Участь у бойових діях & 1 & 2 & 3 & 4 & 5 \\
\hline $\begin{array}{l}\text { Перебування у зоні військового конфлікту } \\
\text { в складі військового формування }\end{array}$ & 1 & 2 & 3 & 4 & 5 \\
\hline $\begin{array}{l}\text { Перебебування у зоні військового конфлікту } \\
\text { як цивільна особа }\end{array}$ & 1 & 2 & 3 & 4 & 5 \\
\hline $\begin{array}{l}\text { Перебування у полоні, заручниках } \\
\text { (викрадення або військовий полон) }\end{array}$ & 1 & 2 & 3 & 4 & 5 \\
\hline 14. Небезпечні для життя хвороби або травми & 1 & 2 & 3 & 4 & 5 \\
\hline 15. Важкі людські страждання & 1 & 2 & & 4 & 5 \\
\hline $\begin{array}{l}\text { Раптова насильницька смерть (вбивство, } \\
\text { самогубство) }\end{array}$ & $\begin{array}{c}\text { He } \\
\text { обирається }\end{array}$ & 2 & 3 & 4 & 5 \\
\hline $\begin{array}{l}\text { Раптова, несподівана смерть будь-кого } \\
\text { поруч з Вами }\end{array}$ & $\begin{array}{c}\text { He } \\
\text { обирається }\end{array}$ & 2 & 3 & 4 & 5 \\
\hline $\begin{array}{l}\text { Серйозна шкода, травми або смерть, яку } \\
\text { Ви заподіяли комусь іншому }\end{array}$ & $\begin{array}{c}1-\text { тільки } \\
\text { якщео Ви } \\
\text { брали } \\
\text { безпосередн } \\
\text { ю участь }\end{array}$ & 2 & 3 & 4 & 5 \\
\hline $\begin{array}{l}\text { Будь-яка інша стресова подія або досвід } \\
\text { (вкажіть): }\end{array}$ & 1 & 2 & 3 & 4 & 5 \\
\hline
\end{tabular}




\section{$x=$ \\ $x=$

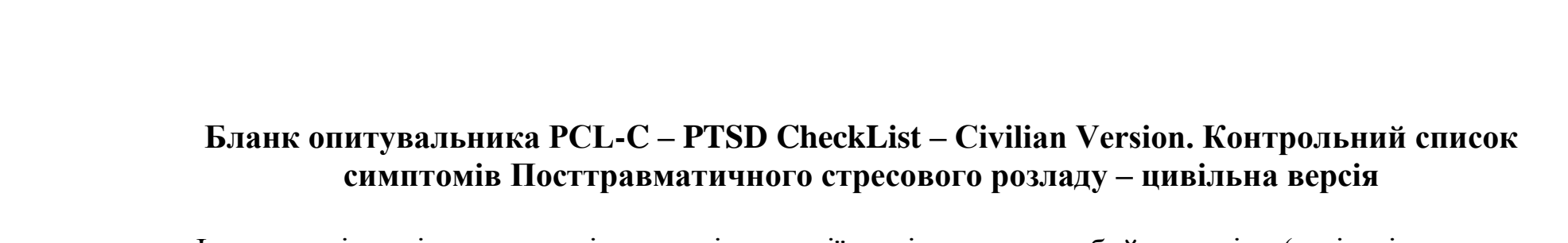

Інколи у відповідь на сильні стресові ситуації, такі як участь у бойових діях (чи інші, перераховані на попередній сторінці), можуть виникати неприємні емоційні реакції. Будь ласка, прочитайте уважно кожне із запитань, а потім обведіть або закресліть номер обраної відповіді справа.

Позначте наскільки Вас хвилювали перелічені проблеми впродовж минулого місяця:

$\begin{gathered}\text { Зовсім } \\ \text { ні }\end{gathered}$
Трохи Помірно $\begin{aligned} & \text { Доволі } \\ & \text { сильно Дуже }\end{aligned}$
сильно

1. 3 голови не виходили спогади, думки або образи стресових подій, турбуючи знову і

виходили спогади, думки або
сових подій, турбуючи знову і
знову

2. Переживав стресові події минулого уві сні

1

2

3

4

5

3. Несподівано відчував начебто стресова подія відбувається заново (ніби ще раз все

$\begin{array}{llll}1 & 2 & 3 & 4\end{array}$

5 переживав)

4. Почувався дуже засмученим, коли щзось нагадувало про стресовий досвід

1

2

34

5

5. Були фізичні реакиії (наприклад, сильно билося серце, було важко дихати, кидало в піт), коли щзось нагадувало про пережитий

$\begin{array}{lllll}1 & 2 & 3 & 4 & 5\end{array}$
стресовий досвід

6. Уникав думок та розмов про пережиті стресові події або уникав почуттів щодо тих подій

7. Уникав щось робити чи бути в якихось ситуаціях, якщо вони нагадували про пережитий стресовий досвід

8. Був не в змозі пригадати важливі моменти стресових подій

1

2

3

Втратив інтерес до речей, які раніше подобалися

10. Відчував віддаленість або відрізаність від інших людей

11. Відчував себе емоиійно онімілим, нездатним відчувати любов до близьких

12. Відчував ніби майбутнє якось раптово обривається

13. Важко було засинати або неспокійний сон

14. Був роздратованим, були спалахи гніву

15. Було важко сконцентрувати увагу

$\begin{array}{llll}1 & 2 & 3 & 4\end{array}$

5

16. Був занадто пильним або обережним, перебував весь час на сторожі

1

2

3

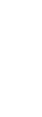

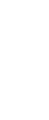

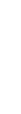

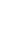

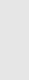

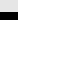

\section{.}

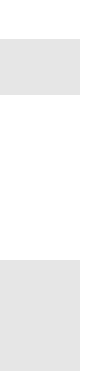

\begin{tabular}{|c|c|c|c|c|c|}
\hline $\begin{array}{l}\text { 6. Був занадто пильним або обережним, } \\
\text { перебував весь час на сторожі }\end{array}$ & 1 & 2 & 3 & 4 & 5 \\
\hline 7. Нервував, легко лякався & 1 & 2 & 3 & 4 & 5 \\
\hline
\end{tabular}


Додаток 1. Інформована згода/дозвіл батьків на участь в дослідженні

№ учасника

Запрошуємо Вас та Вашу дитину до участі в медико-соціальній програмі 3 профілактики порушень здоров'я дітей шкільного віку. Програма започаткована Інститутом психології імені Г.С. Костюка НАПН України та Українським науковометодичним центром практичної психології і соціальної роботи спільно із ДУ «Інститут охорони здоров’я дітей та підлітків Національної академії медичних наук України» та ДУ «Інститут неврології психіатрії та наркології НАМН України».

Метою програми $є$ цілісне формування здоров'язбережувальної компетентності підлітків та їх батьків з особливим фокусом на ризикованій поведінці дітей шкільного віку стосовно власного здоров'я. Програма передбачає проведення семінарів та тренінгів для дітей та їх батьків з урахуванням актуальної соціально-психологічної ситуації, інформація про яку буде формуватися на підставі щорічного опитування підлітків та їх батьків. Опитувальники, що будуть використані, покривають багато тем і включають питання про стиль життя, стан фізичного та психологічного здоров'я, різноманітний досвід, який може негативно вплинути на здоров'я Вашої дитини, а також різні відомості про іiі життя в родині.

Деякі питання є дуже особистими і відповідати на них може бути для Вас некомфортно, але уся надана Вами інформація $є$ конфіденційною (див. нижче) і вкрай важливою для своєчасного проведення попереджувальних заходів.

Конфіденційність: Опитування не анонімне, але вся персональна інформація, яку Ви повідомите, повністю конфіденційна і не може бути піддана розголосу. Це означає, що, у разі невиконання своїх обов'язків, виконавці дослідження несуть відповідальність згідно чинного законодавства. Доступ до документації, відповідно до ст. 16 Закону України «Про захист персональних даних», матимуть лише фахівці Інституту виключно задля забезпечення можливості звернутись до Вас у майбутньому. Заповнений опитувальник буде зберігатись окремо від цієї згоди, на якій будуть зазначені Ваші персональні дані. До Ваших відповідей не буде доступу в осіб, що можуть Вас знати. Відповіді не будуть аналізуватись індивідуально - дані будуть використані тільки після комп'ютерної обробки в узагальненому вигляді.

Ми збираємо Ваші контактні дані, оскільки передбачаємо повторно звертатись до Вас у майбутньому щоб вивчити, як змінюється життя та здоров’я Вашої дитини з часом.

Переваги: Участь у програмі дозволить своєчасно визначити та попередити ризики погіршення здоров'я Вашої дитини, підвищити Вашу та іiі здоров'я-збережувальну компетентність. Дане дослідження повністю відповідає кращим українським та міжнародним етичним стандартам і буде використане для покращення послуг з охорони здоров’я дітям та сім'ям в Україні. Його зміст був оцінений і погоджений комісією 3 питань етики та деонтології ДУ «Інститут охорони здоров'я дітей та підлітків НАМН України»; ДУ «Інститут неврології психіатрії та наркології НАМН України» та комісією 3 етики Університету Мічигану, США.

За здоров'ям Вашої дитини будуть пильно спостерігати фахівці Інституту охорони здоров'я дітей та підлітків НАМН Украӥни, за потребою надавати допомогу та спеціалізовані консультації.

Процедура опитування: У ході цього дослідження Вам буде необхідно відповідати на запитання анкети, це займе у Вас від 30 до 45 хвилин. Номер на анкеті (паперовій або електронній) повинен відповідати номеру на цій згоді (справа зверху).

Ви можете відмовитися від участі або перервати участь в опитуванні в будь-який час, якщо Вам буде некомфортно відповідати на запитання без будь-яких наслідків. Дослідники також мають право припинити Вашу участь в дослідженні без Вашої згоди 3 
будь-яких причин, наприклад, з огляду на безпеку чи для захисту даних. Конфіденційна інформація, вже повідомлена Вами, в такому разі буде знищена.

Якщо у Вас $\epsilon$ питання щодо цього дослідження, Ви можете їх задати відповідальному виконавцю: доктору психологічних наук Щербаковій Олені Олександрівні: тел. +380630372049, e-mail: lenascherbakova@ukr.net або кандидату соціологічних наук Сердюку Олексію Олександровичу: тел. +380503271771, e-mail: serdyuk.alexey@gmail.com

Якщо Ви готові взяти участь в опитуванні «Українське Лонгітюдне Дослідження» та повідомити нам свої персональні дані, а також дасте дозвіл на опитування Вашої дитини поставте свій підпис під «інформованою згодою» нижче.

\section{Інформована згода.}

Підписуючи ц̧ю форму я засвідчую, щзо прочитав викладену вище інформащію, отримав не підписану копію иієї форми, мав можливість задати питання і отримати на них відповіді, підтверджую щуо досліднк роз'яснив мені мету дослідження, ризики, щчо з циим пов'язані та можливість перервати процес дослідження у будь-який час.

Я згодний / згодна взяти участь у цьому дослідженні.

Я надаю дозвіл на участь моєї дитини у цььоу дослідженні.

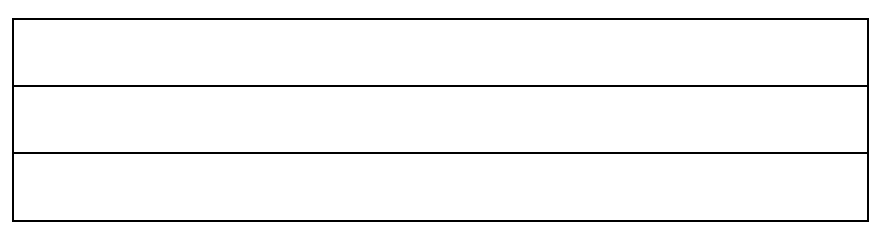

Прізвище, ім’я та по батькові учасника

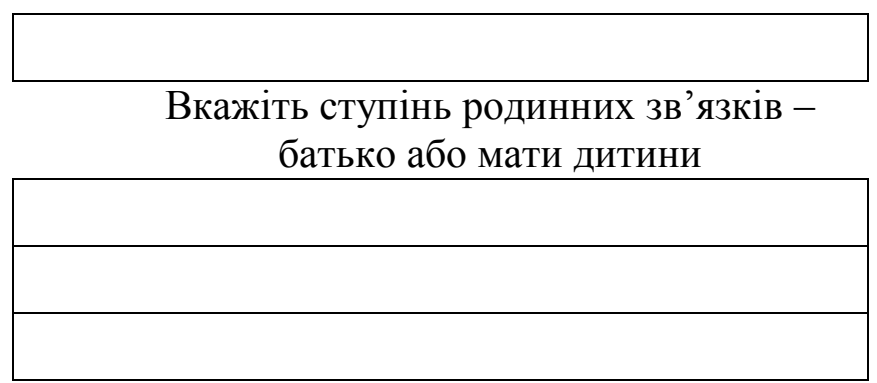

Адреса для листування.

Домашня адреса для повторного

контакту (вул., будинок,

квартира, місто, індекс)

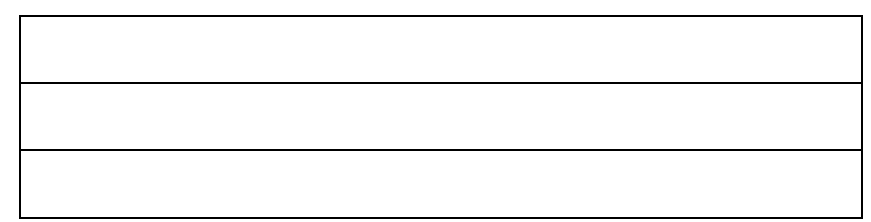

Прізвище, ім'я та по батькові дитини

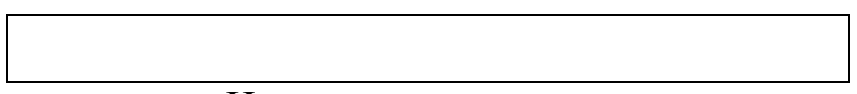

Номер школи, класу дитини

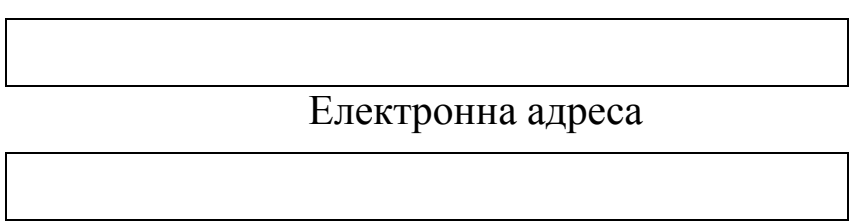

Моб. тел.

Місто, дата

\section{Підпис}

Ви можете заповнити опитувальник на комп 'ютері, планшеті або смартфоні за наведеним посиланням або $Q R$-кодом:

http://survey.intellectfound.org/index.php/627767

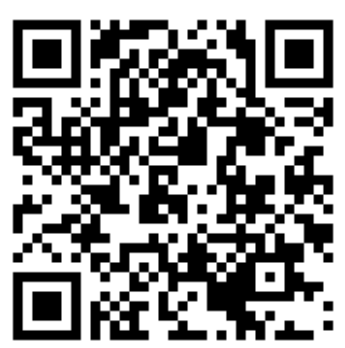


Додаток 2. Інформована згода дитини на участь в дослідженні

(не обов'язковий документ, заповнюється за потреби)

№ учасника

Інформована згода на участь у дослідженні «Українське лонгітюдне дослідження»

учень $\_$класу, __ школи, даю добровільну згоду на участь у цьому анкетуванні, яке проводиться шкільним психологом.

Я розумію, що ця анкета дасть можливість зрозуміти, як події в моєму житті і житті моєї родини впливають на мою поведінку, самопочуття і успішність у школі.

Я мав можливість задати психологу, або іншому педагогічному працівнику, всі запитання, які мене цікавили. Я ознайомлений з тим, що я можу відмовитися від заповнення цієї анкети, хоча відповідати на ці запитання може бути цікаво. Якщо я захочу відмовитися, моя відмова не вплине на мої стосунки 3 учителями i психологами школи та не позначиться на подальшому навчанні в школі.

Моя участь означає, що я буду відповідати на питання в анкеті і це триватиме біля години. Мені відомо, що психолог нікому не розповідатиме про те, що я напишу. Разом з тим, я згоден, що мою анкету можуть побачити ті, хто оброблятиме результати, хоча на анкеті і не буде мого імені і прізвища. Моя анкета допоможе розробити програму виховання школярів, а, можливо, і написати посібник для навчання психологів і лікарів. Але ніхто не дізнається мого імені.

Згоду на проведення анкетування даю добровільно, без будь-якого натиску 3 боку психологів чи учителів. Цю добровільну згоду скріплюю власноручним підписом.

«Прочитав і згідний (згідна) з цим текстом»

“_

(підпис учня або його прізвище)

Прізвище, ім'я та по-батькові інтерв'юера

Місто Дата Підпис 


\section{Додаток 3. Опитувальник ULS для батьків}

Веб-опитувальник виглядає з екрану комп'ютеру або смартфону по-іншому, окремі запитання та стандартизовані опитувальники наведено у форматі «для друку», так як вони виглядають у роздрукованому паперовому опитувальнику

\section{Вступні запитання}

1. Введіть номер (код) учасника, який складається з 14 цифр (повідомляється особою, яка проводить опитування):

\section{2. Опитувальник заповнює:}
1. Мати
2. Батько
3. Інша близька людина (вкажіть хто саме)

\section{3. Ваша стать:}

1. Чоловіча

2. Жіноча

\section{4. Ваша освіта:}

1. Неповна середня і нижче

2. Повна середня

3. Середня спеціальна (технікум тощо)

4. Вища

5. Науковий ступінь

5. Ваш вік (повних років):

6. Ваше сімейне становище:

1. Один, ніколи не був одружений

2. Один, розлучений

3. Вдівець/вдова

4. Одружений, живемо разом

5. Одружений, живемо окремо

6. Живу з партнером (громадянський шлюб)

7. Інше (вкажіть що саме)

7. Ваш зріст $\mathrm{CM}$

8. Вага КГ 


\section{Опитувальник CBCL}

9. Нижче наведено перелік тверджень, які описують дітей. На скільки вірно ці твердження описують ВАШУ ДИТИНУ зараз або протягом останніх 6 місяців? Обведіть, будь ласка, номер обраної відповіді: «2», якщо твердження описує ї̈ дуже вірно або часто вірно; "1», якщо твердження частково або іноді вірне по відноменню до неї; «0», якщо твердження невірно їі описує.

Будь ласка, пищіть друкованими літерами. Будьте пильними, щэоб відповісти на кожне запитання.

$$
\begin{array}{ccc}
0=\text { невірно } & 1=\text { частково або іноді вірно } & 2=\text { дуже вірно або часто } \\
\text { вірно } &
\end{array}
$$

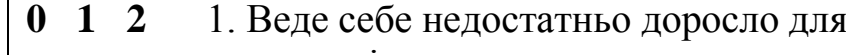
свого віку.

012 2. Вживає алкогольні напої без дозволу батьків (опишіть):

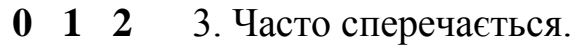

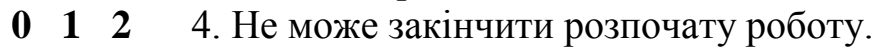

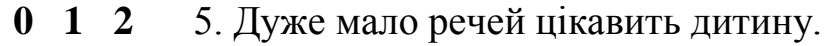

012 6. Випорожнення поза межами туалету.

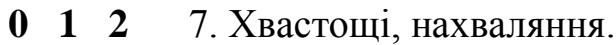

012 8. Не може концентрувати увагу, не може довго бути зосередженою.

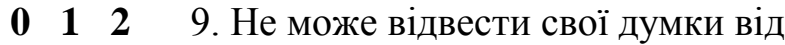
певних тем. Нав'язливі ідеї (опишіть):

012 10. Не може усидіти на місці, невгамовність чи гіперактивність.

012 11. Не може відірватися від дорослих, занадто залежна.

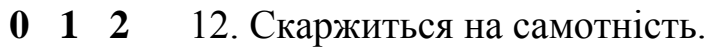

012 13. Збентежена, складає враження відірваності від оточуючого середовища.

012 14. Часто плаче.

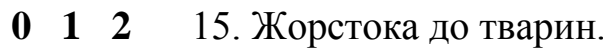

012 16. Жорстокість, цькування інших дітей, підле ставлення до інших людей.

o 12 17. Замріяність, загубленість у своїх думках.

012 18. Умисно травмує себе або пробує вчинити суїцид.

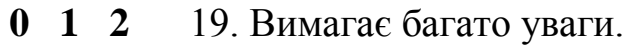

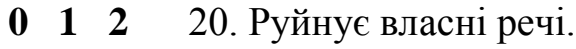

012 21. Руйнує речі, які належать власній родині або іншим людям.

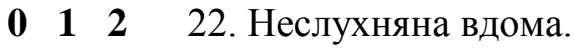

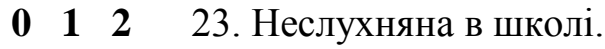

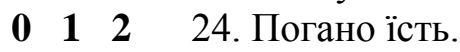

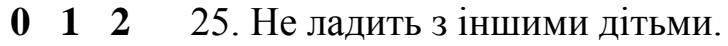

012 26. Складається враження, що дитина не відчуває почуття провини після поганих вчинків.

$\begin{array}{llll}0 & 1 & 27 .\end{array}$

012 28. Порушує поведінку вдома, в школі, в інших місцях.

012 29. Боїться певних тварин, ситуацій, місць, за винятком школи (опишіть):

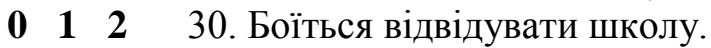

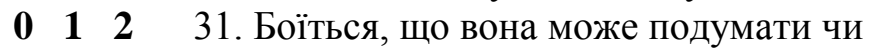
зробити щось негарне.

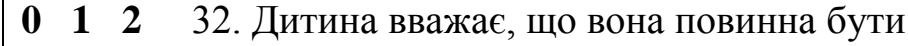
досконалою.

012 33. Вважає (або скаржаться), що ніхто її не любить

012 34. Відчуває, що інші намагаються їі дістати

012 35. Вважає себе нікчемною або неповноцінною людиною.

012 36. Часті травми, дитина схильна до травмування.

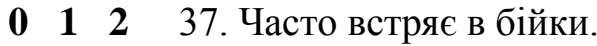

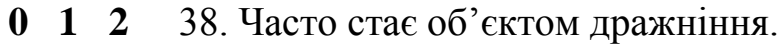

012 39. Водить дружбу з тими, хто порушує дисципліну.

012 40. Чує неіснуючі звуки або голоси (опишіть):

012 41. Імпульсивність або дії без обмірковування.

012 42. Бажає бути самотньою, а не в товаристві.

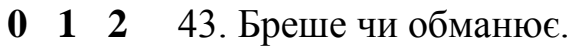

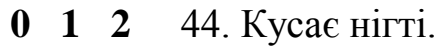

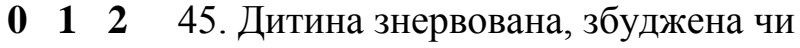
Напружена.

012 46. Нервові рухи або тремтіння (опишіть):

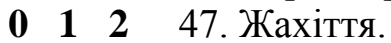

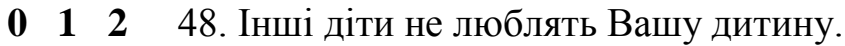

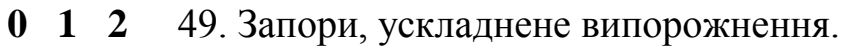

012 50. Занадто боязлива чи тривожна.

012 51. Відчуває запаморочення, головокружіння.

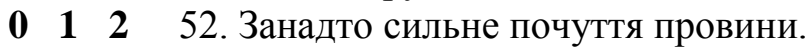

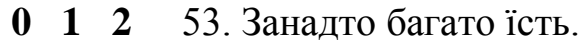

012 54. Надмірна стомлюваність, без достатніх підстав для цього.

012 55. Надлишкова вага.

56. Проблеми з фізичним здоров'ям, без відомої медичної причини (діагнозу):

012 а. Хронічні чи гострі болі (окрім головного болю та болі в області живота).

012 b. Головні болі.

012 с. Нудота, хворобливі відчуття.

012 d. Проблеми із зором (окрім тих, які виправляються окулярами) (опишіть):

012 е. Висипання або інші проблеми із шкірою.

012 f. Болі в області живота.

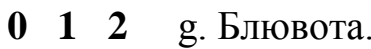

012 h. Інше (опишіть): 
Будь ласка, пишіть друкованими літерами. Будьте пильними, щуоб відповісти на кожне запитання.

0 невірно $1=$ частково або іноді вірно

2 = дуже вірно або часто

вірно

012 57. Фізично нападає на людей.

( 122 58. Колупається в носі, розковирює

о 12 84. Дивна поведінка (опишіть): шкіру чи інші частини тіла (опишіть):

$\begin{array}{llll}0 & 2 & 85 . \text { Дивні міркування (опишіть): }\end{array}$

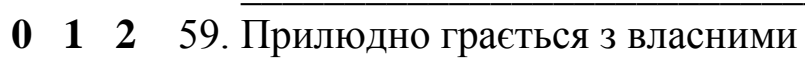
статевими органами.

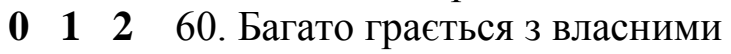
статевими органами.

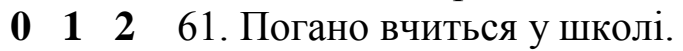

0 12 62. Погана координація рухів.

012 63. Бажає проводити час 3 більш старшими дітьми.

012 64. Бажає проводити час з молодшими дітьми.

0 12 65. Відмовляється розмовляти.

0 12 66. Багаторазово повторює певні дії. Нав'язливі дії (опишіть):

0 122 86. Уперта, похмура чи дратівлива.

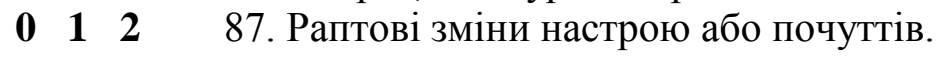

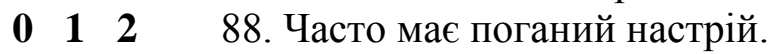

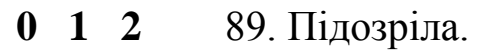

(1) 12 90. Нецензурна чи непристойна мова.

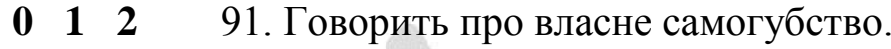

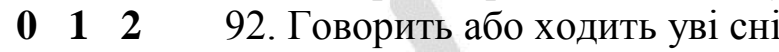

(опишіть):

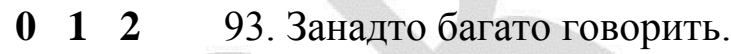

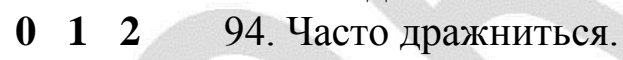

01295. Випадки істерики або запальний характер.

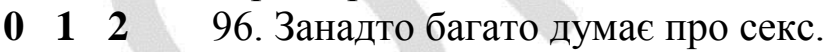

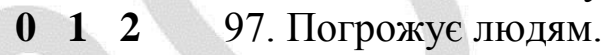

0 12 98. Смокче великий палець.

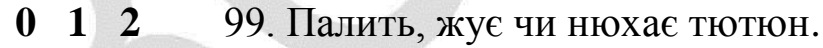

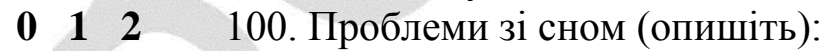

0 12 70. Бачить неіснуючі предмети (опишіть):

101. Прогули, пропуски школи без поважної причини.

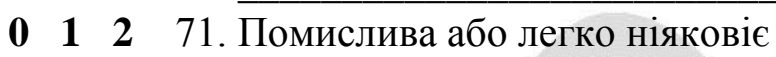

( 1212

102. Недостатньо активна, малорухома,

брак енергіï.

$\begin{array}{lll}\mathbf{0} & 1 & 2\end{array}$

$\begin{array}{lll}0 & 1 & 2\end{array}$

$\begin{array}{lll}0 & 1 & 2\end{array}$

012 74. «Випендрюється» чи робить з себе клоуна.

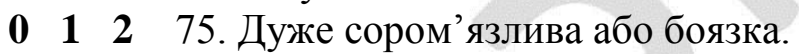

012 76. Спить менше, ніж більшість дітей.

012 77. Протягом дня чи ночі спить довше, ніж більшість дітей (опишіть) :

012 78. Неуважна чи легко відволікається.

012 79. Проблеми з мовленням (опишіть):

0 12 80. Порожній погляд.

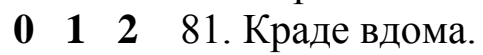

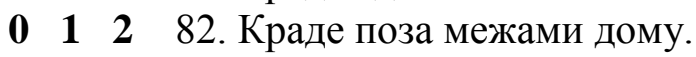

012 83. Запасає занадто багато речей, в яких немає потреби (опишіть):

$\begin{array}{lll}\mathbf{0} & 1 & 2\end{array}$

$\begin{array}{lll}\mathbf{0} & 1 & 2\end{array}$

$\begin{array}{lll}0 & 1 & 2\end{array}$

$\begin{array}{lll}0 & 1 & 2\end{array}$

$\begin{array}{lll}\mathbf{0} & 1 & 2\end{array}$

$\begin{array}{lll}0 & 1 & 2\end{array}$

$\begin{array}{lll}\mathbf{0} & 1 & 2\end{array}$

$\begin{array}{lll}0 & 1 & 2\end{array}$

$\begin{array}{lll}\mathbf{0} & 1 & 2\end{array}$

$\begin{array}{lll}\mathbf{0} & 1 & 2\end{array}$

$\begin{array}{lll}0 & 1 & 2\end{array}$

103. Нещаслива, смутна або пригнічена.

104. Надзвичайно галаслива.

105. Використовує ліки/наркотики для немедичних потреб (окрім алкогольних напоїв та тютюну) (опишіть):

106. Акти вандалізму.

107. Обмочується в денний час.

108. Обмочується в ліжку.

109. Скиглій (часте ниття).

110. Бажає мати протилежну стать.

111. Відлюдькувата, не бажає контактувати 3 іншими людьми.

112. Тривожиться.

113. Будь ласка, наведіть будь-які інші проблеми, які має Ваша дитина, але не вказані вище: 


\section{Опитувальник APQ}

\section{0. Нижче наводиться ряд тверджень про вашу сім'ю. Будь ласка, зазначте, як часто ці події зазвичай відбуваються у Вашій родині.}

Обведіть або закресліть номер обраної відповіді:

1. Ви розмовляєте 3 дитиною як друзі

2. Ви хвалите дитину, коли вона робить щось добре

3. Ви погрожуєте дитині покаранням і не виконуєте цього

4. Ви допомагаєте дитині з позашкільними заняттями (спорт, курси, гуртки, церква ...)

5. Коли дитина Вас слухається чи добре поводиться, Ви іiі заохочуєте чимось особливим - щось даєте або щось додатково дозволяєте

6. Ваша дитина не залишає записку чи не каже, куди йде

7. Ви граєте в ігри або займаєтеся з дитиною іншими цікавими речами

8. Коли ваша дитина провинилася, вона може Вас «переговорити» і уникнути покарання

9. Ви цікавитеся у своєї дитини як пройшов його/ії день у школі 10. Буває, що Ваша дитина повертається ввечері пізніше, ніж мала повернутися

11. Ви допомагаєте своїй дитині робити домашні завдання

12. Ви вважаєте, що змусити дитину послухатися настільки важко, що воно того не варто

13. Ви говорите дитині компліменти, коли вона робить щось добре

14. Ви питаєте, які на сьогодні плани у Вашої дитини

15. Ви водите дитину на заняття, гуртки або секції

16. Ви хвалите дитину за гарну поведінку

17. Ваша дитина гуляє з друзями, яких ви не знаєте

18. Ви обіймаєте або цілуєте свою дитину, коли вона робить щось добре

19. Ваша дитина йде гуляти і ви не обумовлюєте час, коли вона/він має повернутися додому

20. Ви говорите зі своєю дитиною про іï/його друзів

21. Ваша дитина буває на вулиці в темний час доби без супроводу дорослих

22. Ви скорочуєте покарання дитини (наприклад, знімаєте обмеження раніше, ніж казали дитині спочатку)

23. Ваша дитина допомагає планувати сімейні заходи

24. Ви настільки зайняті, що забуваєте, де ваша дитина і що вона/він робить

25. Ви не караєте дитину за неправильні вчинки

26. Ви ходите на батьківські збори в школі

27. Ви говорите дитині, що вам подобається, коли вона/він допомагає вдома

28. Ви не перевіряєте, чи прийшла дитина додому в домовлений час

29. Ви говорите дитині, куди ви йдете

30. Ваша дитина приходить зі школи більш ніж на годину пізніше очікуваного часу

31. Покарання, яке ви влаштовуєте дитині, залежить від Вашого настрою

\begin{tabular}{|c|c|c|c|c|c|}
\hline Ніколи & $\begin{array}{c}\text { Майже } \\
\text { ніколи }\end{array}$ & Іноді & Часто & Завжди \\
\hline 1 & 2 & 3 & 4 & 5 \\
\hline 1 & 2 & 3 & 4 & 5 \\
\hline 1 & 2 & 3 & 4 & 5 \\
\hline 1 & 2 & 3 & 4 & 5 \\
\hline 1 & 2 & 3 & 4 & 5 \\
\hline 1 & 2 & 3 & 4 & 5 \\
\hline 1 & 2 & 3 & 4 & 5 \\
\hline 1 & 2 & 3 & 4 & 5 \\
\hline 1 & 2 & 3 & 4 & 5 \\
\hline 1 & 2 & 3 & 4 & 5 \\
\hline 1 & 2 & 3 & 4 & 5 \\
\hline 0 & 1 & 2 & 3 & 4 & 5 \\
\hline
\end{tabular}




\begin{tabular}{|c|c|c|c|c|c|}
\hline Обведіть або закресліть номер обраної відповіді: & Ніколи & $\begin{array}{l}\text { Майже } \\
\text { ніколи }\end{array}$ & Іноді & Часто & Завжди \\
\hline 32. Ваша дитина буває вдома без нагляду дорослих & 1 & 2 & 3 & 4 & 5 \\
\hline $\begin{array}{l}\text { 33. Ви шльопаєте дитину рукою, коли вона/він щось робить } \\
\text { неправильно }\end{array}$ & 1 & 2 & 3 & 4 & 5 \\
\hline 34. Ви ігноруєте погану поведінку своєї дитини & 1 & 2 & 3 & 4 & 5 \\
\hline $\begin{array}{l}\text { 35. Ви даєте ляпаси своїй дитині (б’єте долонею по обличчю), } \\
\text { якщо вона/він робить щось не так }\end{array}$ & 1 & 2 & 3 & 4 & 5 \\
\hline $\begin{array}{l}\text { 36. Для покарання ви позбавляєте дитину її улюблених занять } \\
\text { (привілеїв) чи не даєте грошей }\end{array}$ & 1 & 2 & 3 & 4 & 5 \\
\hline $\begin{array}{l}\text { 37. Ви відсилаєте дитину в їі/його кімнату (залишаєте вдома) для } \\
\text { покарання }\end{array}$ & 1 & 2 & 3 & 4 & 5 \\
\hline $\begin{array}{l}\text { 38. Ви б'єте дитину ременем, різкою або іншим предметом, якщо } \\
\text { вона/він щось неправильно робить }\end{array}$ & 1 & 2 & 3 & 4 & 5 \\
\hline 39. Ви кричите на свою дитину, якщо вона робить щось не так & 1 & 2 & 3 & 4 & 5 \\
\hline $\begin{array}{l}\text { 40. Ви спокійно пояснюєте дитині, що вона/він зробив/ла } \\
\text { неправильно }\end{array}$ & 1 & 2 & 3 & 4 & 5 \\
\hline $\begin{array}{l}\text { 41. Для покарання ви ставите дитину в кут / садите на стілець } \\
\text { (обмежуєте фізичну активність) }\end{array}$ & 1 & 2 & 3 & 4 & 5 \\
\hline 42. Ви задаєте дитині додаткову роботу в якості покарання & 1 & 2 & 3 & 4 & 5 \\
\hline
\end{tabular}




\section{Опитувальник ASR}

\section{1. На скільки вірно наведені нижче твердження описують ВАС та Вашу поведінку за останні 6 місяців? Обведіть, будь ласка, номер обраної відповіді: «2» якщо твердження}

описує Вас дуже вірно або часто вірно; «1》, якщо твердження частково або іноді вірне по відношенню до Вас; «0» якщо твердження невірно Вас описує.

Будь ласка, пишіть друкованими літерами. Будьте пильними, щзоб відповісти на кожне запитання.

\section{0 = невірно \\ 1 = частково або іноді вірно \\ 2 = дуже вірно або часто}

вірно

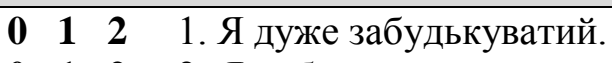

$\begin{array}{llll}0 & 1 & 2 & \text { 2. Я добре використовую свої }\end{array}$ можливості.

$\begin{array}{llll}0 & 1 & 2 & 3 .\end{array}$ Я багато сперечаюсь.

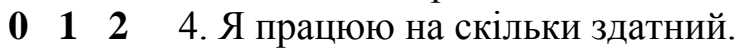

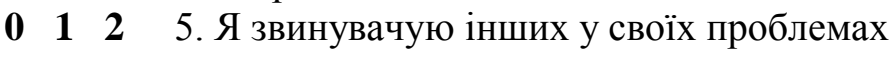

012 6. Я вживаю наркотики (крім алкоголю і нікотину) з немедичними цілями (опишіть які):

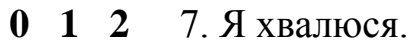

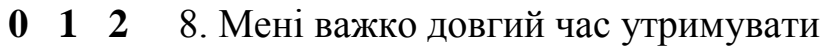
концентрацію уваги.

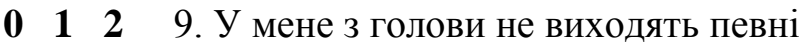
думки (опишіть які):

012 10. Я не можу спокійно всидіти на місці.

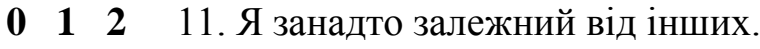

$\begin{array}{llll}0 & 1 & 2 & 12 .\end{array}$

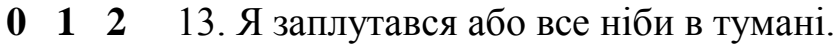

$\begin{array}{llll}0 & 1 & 2 & 14 . \text { Я багато плачу. }\end{array}$

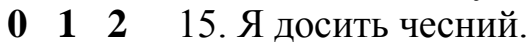

012 16. Я підлий по відношенню до інших.

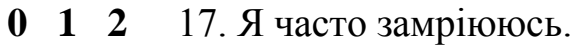

012 18. Я навмисно намагаюсь себе поранити або вбити.

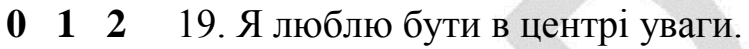

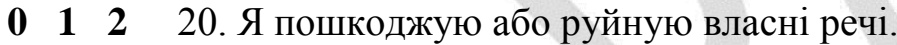

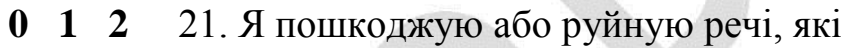
належать іншим.

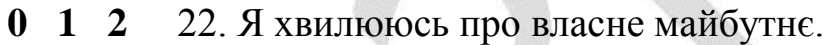

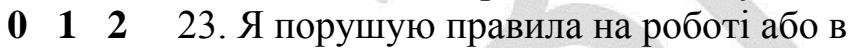
інших місцях.

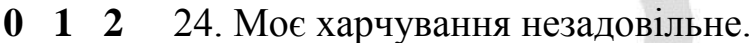

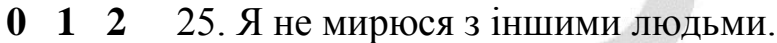

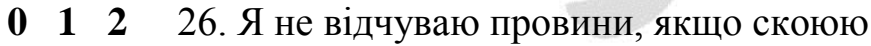
те, що не повинен був робити.

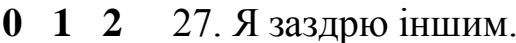

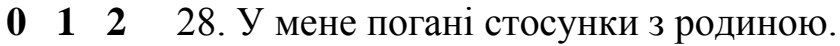

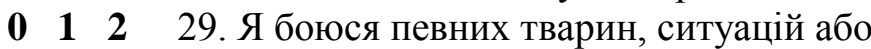
місць (опишіть):

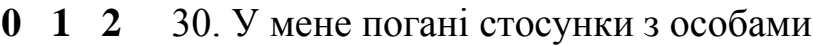
протилежної статі.

012 31. Я боюся, що можу думати або робити щось погане.

012 32. Я відчуваю, що повинен бути досконалим.

012 33. Я відчуваю, що ніхто мене не любить

012 34. Я відчуваю, що інші намагаються мене дістати.
012 35. Я відчуваю себе нікчемним або неповноцінним.

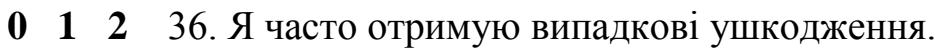

012 37. Я постійно встряю в бійки.

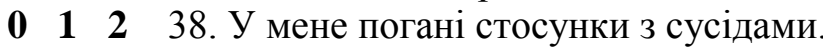

012 39. Серед моїх знайомих є такі, що постійно шукають проблем (влазять у халепи).

012 40. Я чую звуки або голоси, які не чують інші (опишіть):

012 41. Я імпульсивний або дію не подумавши.

012 42. Я скоріше буду наодинці, ніж 3 іншими.

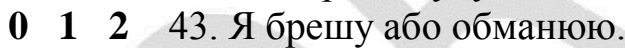

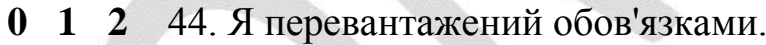

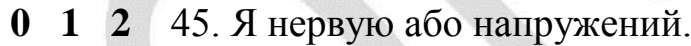

012 46. Частини мого тіла сіпаються або роблять нервові рухи (опишіть):

012 47. Мені бракує впевненості у собі.

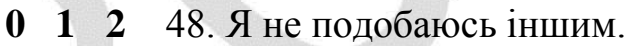

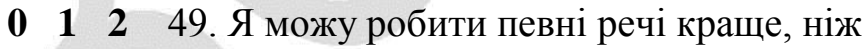
інші люди.

012 50. Я занадто боязливий або тривожний.

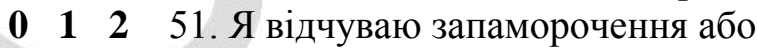
головокружіння.

$\begin{array}{llll}0 & 1 & 2 & 52 .\end{array}$

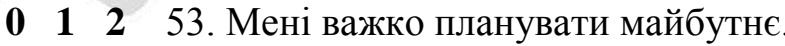

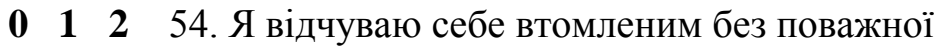
причини.

012 55. Мій настрій гойдається між радістю і депресією.

56. В мене с фізичні проблеми без відомої медичної причини (діагнозу), а саме:

012 а. Хронічні чи гострі болі (окрім головного болю та болю в області живота)

012 b. Головні болі.

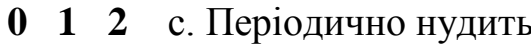

012 d. Проблеми з очима (не ті, що виправляються окулярами або лінзами) (опишіть):

012 е. Висипання або інші проблеми зі шкірою

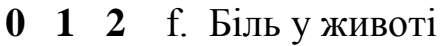

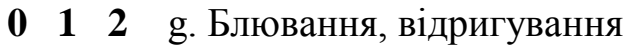

0 12 h. Серцебиття, часте колотіння

012 і. Оніміння або поколювання в частинах тіла

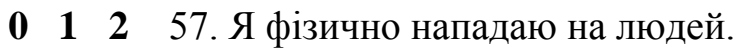

012 58. Часом я шкребу (дряпаю) собі шкіру чи інші частини тіла (опишіть):

012 59. Я не довожу до кінця важливі справи. 
Будь ласка, пишіть друкованими літерами. Будьте пильними, щуоб відповісти на кожне запитання.

0 невірно $1=$ частково або іноді вірно

2 = дуже вірно або часто

вірно

012 60. Мені мало що подобається, мало що мене радує.

0 12 61. У мене низька продуктивність праці.

012 62. У мене погана координація, я незграбний.

012 63. Я вважаю за краще бути зі старшими за мене людьми, ніж з людьми мого віку.

012 64. У мене проблеми з визначенням пріоритетів.

012 65. Я відмовляюсь розмовляти.

( 122 66. Повторюю певні дії знову і знову (опишіть які):

012 67. Мені важко заводити або зберігати друзів

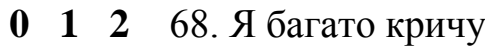

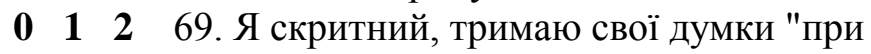
собі"

012 70. Я бачу образи/сцени, які іншим людям вважаються неіснуючими (опишіть):

012 71. Я помисливий або легко ніяковію

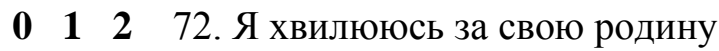

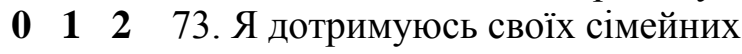
обов'язків.

012 74. Я «випендрююсь» або займаюсь клоунадою.

012 75. Я дуже сором'язливий чи боязкий

012 76. Моя поведінка безвідповідальна.

012 77. Я сплю більше, ніж інші люди впродовж дня i/aбо ночі (конкретизуйте):

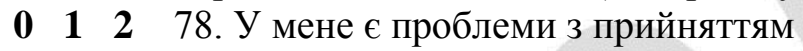
рішень.

012 79. У мене $\epsilon$ проблеми мовлення (опишіть):

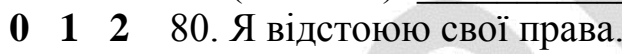

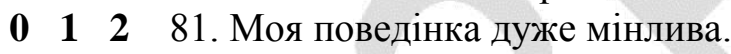

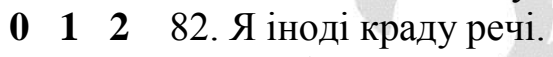

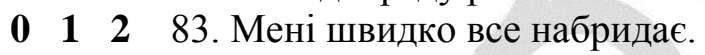

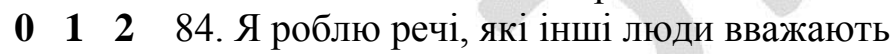
дивними (опишіть):

012 85. У мене є думки, які інші люди вважають дивними (опишіть):

012 86. Я впертий, похмурий або дратівливий

012 87. Мій настрій або почуття раптово змінюються.

012 88. Мені подобається бути з людьми.

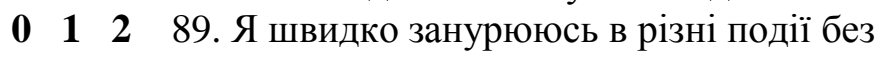
урахування ризиків.

012 90. Я вживаю забагато алкоголю або буваю напідпитку.

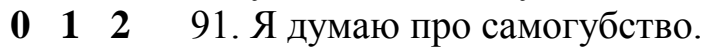

$\begin{array}{lll}\mathbf{0} & 1 & 2\end{array}$

92. Я роблю вчинки, що можуть привести до неприємностей із законом (опишіть):

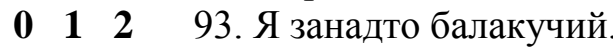

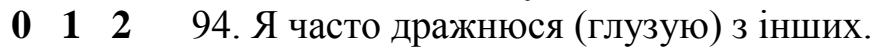

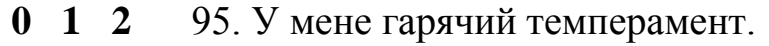

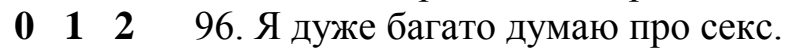

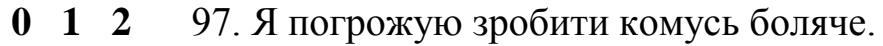

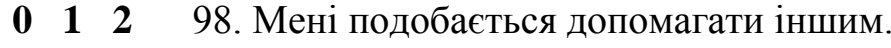

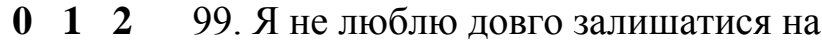
одному місці.

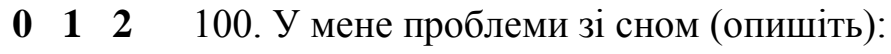

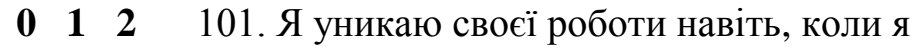
не хворий і не у відпустці.

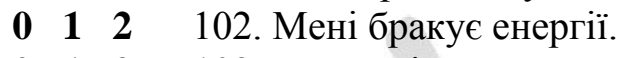

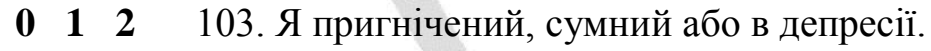

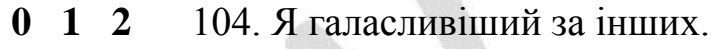

012 105. Люди думають, що я неорганізований.

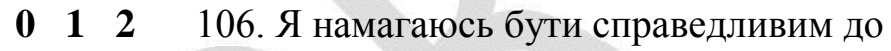
інших.

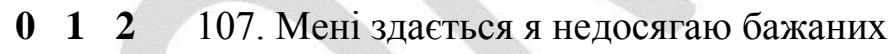
результатів.

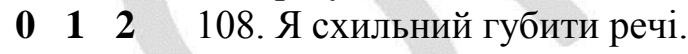

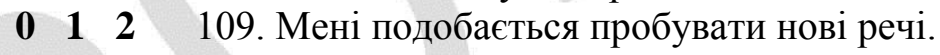

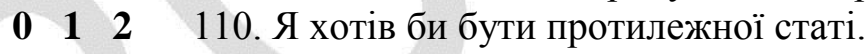

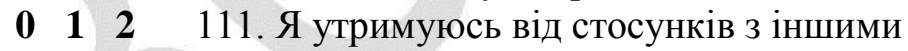

$\begin{array}{llll}\mathbf{0} & 1 & 2 & 112 . \text { Я багато хвилююсь }\end{array}$

0 12 113. Мене непокоять стосунки 3 протилежною статтю

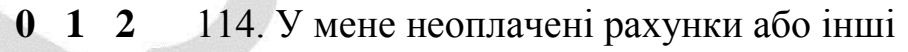
фінансові труднощі

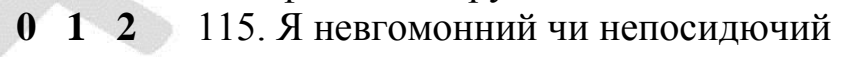

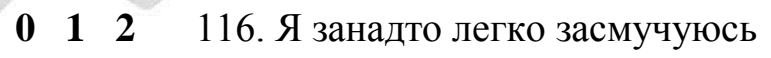
(розстроююся)

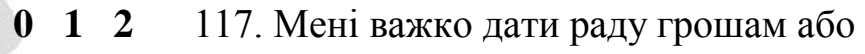
кредитним карткам

$\begin{array}{llll}0 & 1 & 2 & 118 . \text { Я занадто нетерплячий }\end{array}$

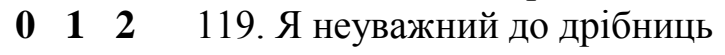

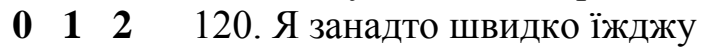

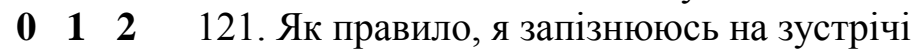

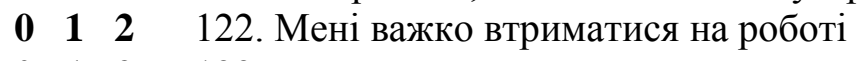

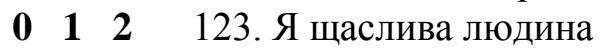

124. Протягом останніх 6 місяців, приблизно,

скільки разів на день Ви вживаєте тютюн, курите (в тому числі електронні сигарети, жувальний табак та ін.)? разів на день

125. Протягом останніх 6 місяців, приблизно, скільки днів Ви були напідпитку? (вкажіть число) днів

126. Протягом останніх 6 місяців скільки було днів, коли Ви використовували наркотичні речовини (марихуану, кокаїн чи інші, крім алкоголю і нікотину)? (вкажіть число) днів 


\section{Опитувальник AUDIT-C}

\section{2. Наступні запитання стосуються вживання алкоголю:}

1. Як часто Ви вживаєте алкоголь? (приблизно)

\begin{tabular}{|c|c|c|c|c|}
\hline Ніколи & $\begin{array}{c}\text { Раз на місяць або } \\
\text { рідше }\end{array}$ & $\begin{array}{c}2-4 \text { рази на } \\
\text { місяць }\end{array}$ & $\begin{array}{c}2-3 \text { рази на } \\
\text { тиждень }\end{array}$ & $\begin{array}{c}4 \text { або більше разів } \\
\text { на тиждень }\end{array}$ \\
\hline 1 & 2 & 3 & 4 & 5 \\
\hline
\end{tabular}

Якщу Ви не n'єте - переходьте до запитання 10 на наступній сторінці.

Стандартна доза - ие приблизно рюмка/чарка міцних напоїв (30 мл), бокал вина (150 мл), пляшка/кружка пива $(0,5 \pi)$.

\section{2. Скільки стандартних доз алкогольних напоїв Ви зазвичай випиваєте в день (коли п’єте)?}

\begin{tabular}{|c|c|c|c|c|}
\hline $1-2$ або менше & $3-4$ & $5-6$ & $7-9$ & 10 або більше \\
\hline 1 & 2 & 3 & 4 & 5 \\
\hline
\end{tabular}

3. Як часто Ви випиваєте шість і більше стандартних доз алкогольних напоїв за раз? (приблизно)

\begin{tabular}{|c|c|c|c|c|}
\hline Ніколи & Рідше разу на місяць & Раз на місяць & Раз на тиждень & Щодня або майже щодня \\
\hline 1 & 2 & 3 & 4 & 5 \\
\hline
\end{tabular}

13. Чи хворіли Ви або Ваші близькі / знайомі на коронавірус (у минулому або зараз)? (можливо обрати декілька варіантів)

1. НІ - ні я ні мої близькі та знайомі не хворіли на коронавірус

2. Я особисто хворів (ла) на коронавірус

3. Мої діти хворіли на коронавірус

4. Члени моєї родини (батьки, брат, сестра ...) хворіли на коронавірус

5. Мій партнер (чоловік, дружина ...) хворіли на коронавірус

6. Мій друг/подруга хворіли на коронавірус

7. Мої знайомі хворіли на корона вірус

8. Інше (напишіть що саме): 


\section{Додаток 4. Опитувальник ULS для дітей}

Веб-опитувальник виглядає з екрану комп'ютеру або смартфону по-іншому, окремі запитання та стандартизовані опитувальники наведено у форматі «для друку», так як вони виглядають у

\section{роздрукованому паперовому опитувальнику}

\section{Стартова сторінка}

Запрошуємо тебе до участі в медико-соціальній програмі з профілактики порушень здоров'я дітей шкільного віку. Опитувальник, який ми пропонуємо тобі заповнити, покриває багато тем i включає питання про стиль життя, стан фізичного та психологічного здоров'я, різноманітний досвід, який може негативно вплинути на твоє здоров'я, а також різні відомості про твоє життя в родині.

Електронний опитувальник повністю анонімний. До твоїх відповідей не буде доступу у батьків, вчителів та інших осіб, що можуть тебе знати. Вся повідомлена тобою інформація повністю конфіденційна і не може бути піддана розголосу.

Процедура опитування: Заповнення опитувальника зазвичай займає близько 1 години і для нас дуже важливо, щоб ти відверто і повно відповів на всі поставлені запитання.

Якщо ти готовий (готова) розпочати натисни "Далі".

\section{Вступні запитання}

1. Введіть номер (код) учасника, який складається з 14 цифр (повідомляється особою, яка проводить опитування):

\section{2. Ваша стать:}

1. Чоловіча

2. Жіноча

3. Ваш вік (повних років):

4. Baш зpict $\mathrm{CM}$

5. Вага Кг

\section{Опитувальник APQ}

6. Ми хочемо зрозуміти, в яких ти стосунках з люди, з якими постійно бачишся (члени родини, друзі, батьки, брати та сестри). Для кожної людини скажи, чи ця людина є для тебе важливою. Також відзнач чи мешкас ця людина з тобою разом під одним дахом?

Якщо такої людини немає - нічого не відмічай у відповідному рядку.

Обведи або закресли обрану відповідь,:

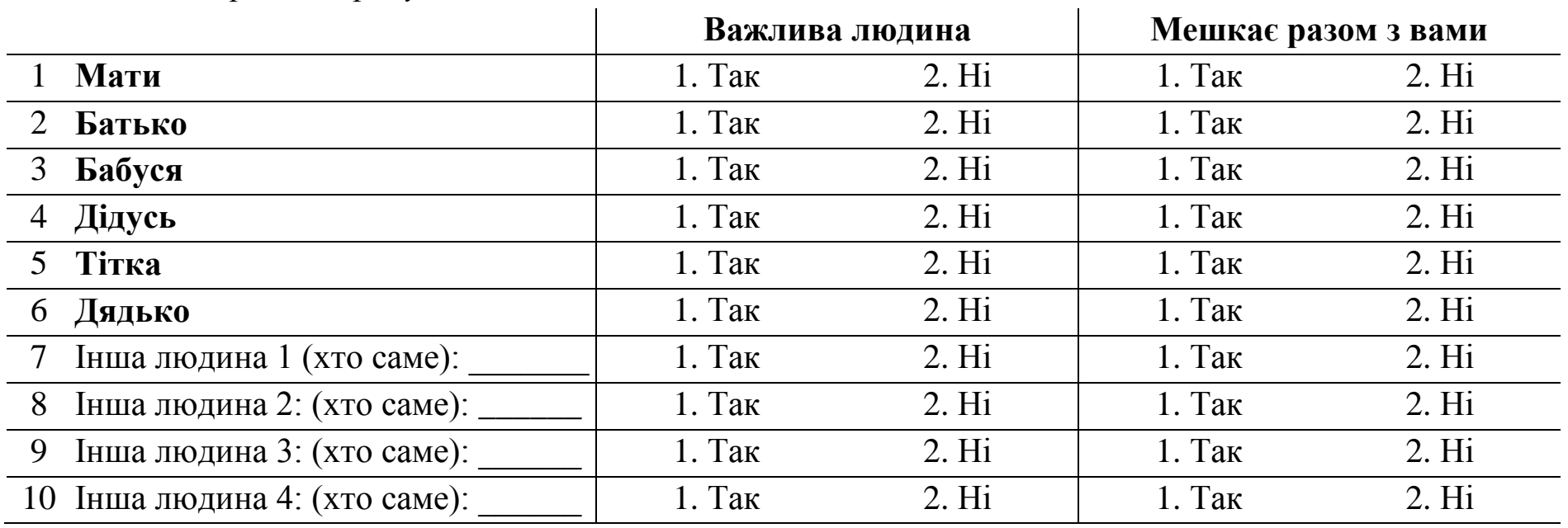


7. Наступні запитання про Твої стосунки із батьками чи людьми, які Тебе виховують. Якщо Тебе виховують прийомні батьки, бабуся, дідусь чи інший член родини - відповідай про стосунки з ними.

\begin{tabular}{|c|c|c|c|c|c|c|}
\hline & Обведи або закресли номер обраної відповіді: & $\underset{1}{3}$ & 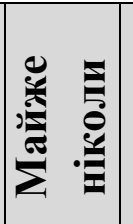 & 产 & 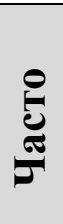 & 岂 \\
\hline 1 & Чи можеш ти відверто говорити з мамою & 1 & 2 & 3 & 4 & 5 \\
\hline $1 \mathrm{a}$ & Чи можеш ти відверто говорити з батьком & 1 & 2 & 3 & 4 & 5 \\
\hline $1 \mathrm{~b}$ & $\begin{array}{l}\text { Чи можеш ти відверто говорити з іншим членом родини, який } \\
\text { тебе виховує (вкажи, хто це): }\end{array}$ & 1 & 2 & 3 & 4 & 5 \\
\hline 2 & Батьки тобі кажуть, що Ти молодець & 1 & 2 & 3 & 4 & 5 \\
\hline 3 & $\begin{array}{l}\text { Твої батьки лякають тебе покараннями, але потім їх не } \\
\text { виконують }\end{array}$ & 1 & 2 & 3 & 4 & 5 \\
\hline 4 & $\begin{array}{l}\text { Твоя мати допомагає тобі в позашкільних заняттях (спорт, } \\
\text { гуртки та ін.) }\end{array}$ & 1 & 2 & 3 & 4 & 5 \\
\hline $4 \mathrm{a}$ & $\begin{array}{l}\text { Твій батько допомагає тобі в позашкільних заняттях (спорт, } \\
\text { гуртки та ін.) }\end{array}$ & 1 & 2 & 3 & 4 & 5 \\
\hline $4 \mathrm{~b}$ & $\begin{array}{l}\text { Чи допомагає тобі в позашкільних заняттях (спорт, гуртки та } \\
\text { ін.) інший член родини, який тебе виховує } \\
\text { (вкажи, хто це): }\end{array}$ & 1 & 2 & 3 & 4 & 5 \\
\hline 5 & Твої батьки винагороджують тебе, якщо ти добре поводитеся & 1 & 2 & 3 & 4 & 5 \\
\hline 6 & $\begin{array}{l}\text { Ти не залишаєш повідомлення або не говориш батькам, куди } \\
\text { Ти збираєшся йти }\end{array}$ & 1 & 2 & 3 & 4 & 5 \\
\hline 7 & Ти граєш в ігри або робиш інші цікаві речі з мамою & 1 & 2 & 3 & 4 & 5 \\
\hline $7 \mathrm{a}$ & Ти граєш в ігри або робиш інші цікаві речі з батьком & 1 & 2 & 3 & 4 & 5 \\
\hline $7 b$ & $\begin{array}{l}\text { Ти граєш в ігри або робиш інші цікаві речі з іншим членом } \\
\text { родини, який тебе виховує (вкажи, хто це) }\end{array}$ & 1 & 2 & 3 & 4 & 5 \\
\hline 8 & Ти «домовляєшся» з батьками і уникаєш покарань за провини & 1 & 2 & 3 & 4 & 5 \\
\hline 9 & Твоя мама питає, як пройшов твій день у школі & 1 & 2 & 3 & 4 & 5 \\
\hline $9 \mathrm{a}$ & Твій батько питає, як пройшов твій день у школі & 1 & 2 & 3 & 4 & 5 \\
\hline $9 b$ & $\begin{array}{l}\text { Чи питає, як пройшов твій день у школі, інший член родини, } \\
\text { який тебе виховує (вкажи, хто це) }\end{array}$ & 1 & 2 & 3 & 4 & 5 \\
\hline 10 & Ти гуляєш у вечірній час довше, ніж Тобі дозволяється & 1 & 2 & 3 & 4 & 5 \\
\hline 11 & Твоя мама допомагає тобі з домашніми завданнями & 1 & 2 & 3 & 4 & 5 \\
\hline $11 \mathrm{a}$ & Твій батько допомагає тобі з домашніми завданнями & 1 & 2 & 3 & 4 & 5 \\
\hline $11 b$ & $\begin{array}{l}\text { Чи допомагає тобі з домашніми завданнями інший член } \\
\text { родини, який тебе виховує (вкажи, хто це) }\end{array}$ & 1 & 2 & 3 & 4 & 5 \\
\hline 12 & $\begin{array}{l}\text { Примусити тебе слухатися настільки важко, що батьки від } \\
\text { цього відмовляються }\end{array}$ & 1 & 2 & 3 & 4 & 5 \\
\hline 13 & Батьки хвалять тебе, коли ти добре щось робиш & 1 & 2 & 3 & 4 & 5 \\
\hline 14 & Мама питає про твої плани на день & 1 & 2 & 3 & 4 & 5 \\
\hline $14 \mathrm{a}$ & Батько питає про твої плани на день & 1 & 2 & 3 & 4 & 5 \\
\hline $14 b$ & $\begin{array}{l}\text { Чи питає про твої плани на день інший член родини, який тебе } \\
\text { виховує (вкажи, хто це) }\end{array}$ & 1 & 2 & 3 & 4 & 5 \\
\hline
\end{tabular}


Обведи або закресли номер обраної відповіді:

15 Мама водить тебе на позашкільні заходи

15a Тато водить тебе на позашкільні заходи

$15 \mathrm{~b}$ Чи водить тебе на позашкільні заходи інший член родини, який тебе виховує (вкажи, хто це)

16 Батьки хвалять тебе за гарну поведінку

17 Батьки не знають друзів, з якими ти проводиш час

18 Батьки обіймають або цілують тебе, коли ти робиш щось дуже 18 добре

19 Ти ходиш гуляти без встановленого часу, коли треба бути 19 вдома

20 Мама говорить 3 тобою про твоїх друзів

20а Батько говорить 3 тобою про твоїх друзів

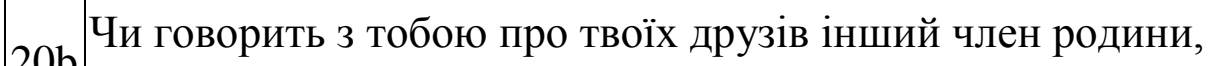

$20 \mathrm{~b}$ який тебе виховує (вкажи, хто це)

21 Ти ходиш на прогулянки після настання темряви без супроводу дорослих

22 Батьки припиняють покарання (знімають обмеження) раніше встановленого терміну

23 Ти допомагаєш планувати сімейні заходи

24 Твої батьки бувають настільки зайняті, що забувають, де ти і

24 що робиш

25 Батьки не карають тебе, коли ти робиш щось неправильно

26 Твоя мама ходить до школи на батьківські збори/зустрічі 3 26 вчителями.

26а Твій батько ходить до школи на батьківські збори/зустрічі 3 вчителями

$26 \mathrm{~b}$ Чи ходить до школи на батьківські збори/зустрічі з вчителями інший член родини, який тебе виховує (вкажи, хто це)

27 Батьки кажуть тобі, що це їм подобається, коли Ти

27 допомагаєш по дому

28 Ти гуляєш довше, ніж було дозволено і батьки про це не 28 Здогадуються

29 Коли твої батьки йдуть 3 дому, вони не кажуть Тобі, куди вони йдуть

30 Ти приходиш із школи додому більш ніж на годину пізніше

30 часу, коли батьки тебе очікують

31 Покарання від твоїх батьків залежить від їхнього настрою

32 Тебе залишають вдома самого, без дорослих

33 Батьки шльопають тебе рукою, коли ти робиш щось

33 неправильно

$\left|\begin{array}{l}1 \\ 1 \\ 1\end{array}\right|$

\begin{tabular}{l|l|l|l|}
2 & 3 & 4 & 5 \\
2 & 3 & 4 & 5
\end{tabular}

\begin{tabular}{l|l|l|l}
2 & 3 & 4 & 5
\end{tabular}

\begin{tabular}{|l|l|l|l|l}
1 & 2 & 3 & 4 & 5 \\
\hline 1 & 2 & 3 & 4 & 5 \\
1 & 2 & 3 & 4 & 5
\end{tabular}

\begin{tabular}{|l|l|l|l|l}
1 & 2 & 3 & 4 & 5 \\
1 & 2 & 3 & 4 & 5 \\
1 & 2 & 3 & 4 & 5 \\
1 & 2 & 3 & 4 & 5 \\
1 & 2 & 3 & 4 & 5
\end{tabular}

\begin{tabular}{|l|l|l|l|l}
1 & 2 & 3 & 4 & 5 \\
1 & 2 & 3 & 4 & 5 \\
1 & 2 & 3 & 4 & 5 \\
1 & 2 & 3 & 4 & 5 \\
1 & 2 & 3 & 4 & 5
\end{tabular}

\begin{tabular}{|l|l|l|l|l}
1 & 2 & 3 & 4 & 5 \\
1 & 2 & 3 & 4 & 5 \\
1 & 2 & 3 & 4 & 5 \\
1 & 2 & 3 & 4 & 5 \\
1 & 2 & 3 & 4 & 5
\end{tabular}

\begin{tabular}{|l|l|l|l|l|}
1 & 2 & 3 & 4 & 5 \\
\hline 1 & 2 & 3 & 4 & 5 \\
\hline
\end{tabular}

\begin{tabular}{|l|l|l|l|l|}
1 & 2 & 3 & 4 & 5 \\
1 & 2 & 3 & 4 & 5 \\
1 & 2 & 3 & 4 & 5 \\
\hline
\end{tabular}

\begin{tabular}{|c|c|c|c|c|}
\hline 1 & 2 & 3 & 4 & 5 \\
1 & 2 & 3 & 4 & 5 \\
\hline 1 & 2 & 3 & 4 & 5 \\
\hline 1 & 2 & 3 & 4 & 5 \\
\hline 1 & 2 & 3 & 4 & 5 \\
\hline 1 & 2 & 3 & 4 & 5 \\
\hline 1 & 2 & 3 & 4 & 5 \\
\hline 1 & 2 & 3 & 4 & 5 \\
\hline 1 & 2 & 3 & 4 & 5 \\
\hline
\end{tabular}




\begin{tabular}{|c|c|c|c|c|c|c|}
\hline & Обведи або закресли номер обраної відповіді: & : & 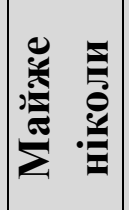 & 突 & 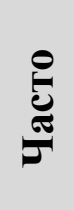 & \\
\hline 34 & Батьки ігнорують твою погану поведінку & 1 & 2 & 3 & 4 & 5 \\
\hline 35 & $\begin{array}{l}\text { Батьки дають тобі ляпаса (б’ють долонею по обличчю), коли } \\
\text { ти робиш щось неправильно }\end{array}$ & 1 & 2 & 3 & 4 & 5 \\
\hline 36 & $\begin{array}{l}\text { Батьки позбавляють тебе улюблених занять (привілеїв) або } \\
\text { забирають гроші в якості покарання }\end{array}$ & 1 & 2 & 3 & 4 & 5 \\
\hline 37 & $\begin{array}{l}\text { Батьки відправляють тебе в твою кімнату (залишають вдома) } \\
\text { як покарання }\end{array}$ & 1 & 2 & 3 & 4 & 5 \\
\hline 38 & $\begin{array}{l}\text { Батьки можуть вдарити тебе ременем, прутом або іншим } \\
\text { предметом, коли ти робиш щось неправильно }\end{array}$ & 1 & 2 & 3 & 4 & 5 \\
\hline 39 & Батьки кричать на тебе, коли ти робиш щось неправильно & 1 & 2 & 3 & 4 & 5 \\
\hline 40 & $\begin{array}{l}\text { Батьки спокійно пояснюють тобі, чому твоя поведінка була } \\
\text { неправильною, якщо ти погано поводився }\end{array}$ & 1 & 2 & 3 & 4 & 5 \\
\hline 41 & $\begin{array}{l}\text { Батьки ставлять тебе в кут / садять на стілець (обмежують } \\
\text { фізичну активність) в якості покарання }\end{array}$ & 1 & 2 & 3 & 4 & 5 \\
\hline 42 & Батьки дають тобі додаткову роботу в якості покарання & 1 & 2 & 3 & 4 & 5 \\
\hline
\end{tabular}




\section{Опитувальник YSR}

8. Нижче наведено перелік тверджень, які описують дітей. Навпроти кожного речення, що описує Тебе зараз або за останні 6 місящів, обведи, будь ласка, 2, якщо твердження описує Тебе дуже вірно або часто вірно. Обведи 1 , якщо твердження частково або іноді вірне по відношенню до тебе. Якщо твердження невірно Тебе описує, обведи $\mathbf{0 .}$

$$
\text { 0 = невірно } 1 \text { = частково або іноді вірно }
$$

\begin{tabular}{|c|c|c|c|c|c|c|c|}
\hline (0 & 1 & 2 & $\begin{array}{l}\text { 1. Я поводжуся як значно молодший/а } \\
\text { свого віку. }\end{array}$ & $\mathbf{0}$ & 1 & 2 & $\begin{array}{l}\text { 34. Я відчуваю, що інші намагаються мене } \\
\text { дістати. }\end{array}$ \\
\hline $\mathbf{0}$ & 1 & 2 & $\begin{array}{l}\text { 2. Я п'ю спиртне без дозволу батьків. } \\
\text { (опиши) }\end{array}$ & $\mathbf{0}$ & 1 & 2 & $\begin{array}{l}\text { 35. Я почуваюся нічого не вартим або } \\
\text { неповноцінним. }\end{array}$ \\
\hline $\mathbf{0}$ & 1 & 2 & 3. Я багато сперечаюся. & $\mathbf{0}$ & 1 & 2 & 36. Зі мною часто трапляються нещасні \\
\hline 0 & 1 & 2 & $\begin{array}{l}\text { 4. У мене не виходить доводити до } \\
\text { кіншя справи, які я починаю. }\end{array}$ & & 1 & 2 & $\begin{array}{l}\text { випадки. } \\
\text { 37. Я часто потра }\end{array}$ \\
\hline $\mathbf{0}$ & 1 & 2 & 5. Мало що приносить мені радість. & & 1 & 2 & 38. Мене часто дражнять. \\
\hline $\mathbf{0}$ & 1 & 2 & 6. Я люблю тварин. & $\mathbf{0}$ & 1 & 2 & 39. Я дружу з дітьми, які попадають у \\
\hline & 1 & 2 & 7. Я вихваляюся. & & & & халепи. \\
\hline $\mathbf{0}$ & 1 & 2 & $\begin{array}{l}\text { 8. Мені складно сконцентруватися або } \\
\text { бути уважним. }\end{array}$ & $\mathbf{0}$ & 1 & 2 & $\begin{array}{l}\text { 40. Я чую звуки та голоси, які інші люди не } \\
\text { чують (опиши) }\end{array}$ \\
\hline $\mathbf{0}$ & $\mathbf{1}$ & 2 & $\begin{array}{l}\text { 9. У мене з голови не виходять деякі } \\
\text { думки (опиши) }\end{array}$ & & 1 & $\begin{array}{l}2 \\
2\end{array}$ & $\begin{array}{l}\text { 41. Я спочатку щось роблю, а потім думаю. } \\
\text { 42. Я вважаю за краще бути наодинці, ніж }\end{array}$ \\
\hline $\mathbf{0}$ & 1 & 2 & 10. Мені важко сидіти спокійно. & & & & з іншими. \\
\hline $\mathbf{0}$ & 1 & 2 & 11. Я дуже залежу від дорослих. & $\mathbf{0}$ & 1 & 2 & 43. Я обманюю або обдурюю інших. \\
\hline $\mathbf{0}$ & 1 & 2 & 12. Я почуваю себе самотнім. & $\mathbf{0}$ & 1 & 2 & 44. Я гризу нігті. \\
\hline $\mathbf{0}$ & 1 & 2 & $\begin{array}{l}\text { 13. Я почуваюся заплутаним або в } \\
\text { тумані. }\end{array}$ & & 1 & $\begin{array}{l}2 \\
2\end{array}$ & $\begin{array}{l}\text { 45. Я нервований або напружений. } \\
\text { 46. Частини мого тіла смикаються або }\end{array}$ \\
\hline $\mathbf{0}$ & 1 & 2 & 14. Я багато плачу. & & & & роблять нервові рухи (опиши) \\
\hline $\mathbf{0}$ & 1 & 2 & 15. Я досить чесний. & $\mathbf{0}$ & 1 & 2 & 47. Мені сняться жахіття. \\
\hline $\mathbf{0}$ & $\mathbf{1}$ & 2 & 16. Я підло поводжуся з іншими. & $\mathbf{0}$ & 1 & 2 & 48. Інші діти мене не люблять. \\
\hline $\mathbf{0}$ & 1 & 2 & 17. Я часто замріююся (мрію). & $\mathbf{0}$ & 1 & 2 & 49. Я можу робити деякі справи краще, ніж \\
\hline $\mathbf{0}$ & 1 & 2 & $\begin{array}{l}\text { 18. Я роблю навмисні спроби зробити } \\
\text { собі боляче або вбити себе. }\end{array}$ & & & & $\begin{array}{l}\text { більшість дітей. } \\
\text { 50. Я надмірно боязливий(а) або }\end{array}$ \\
\hline $\mathbf{0}$ & 1 & 2 & $\begin{array}{l}\text { 19. Я часто намагаюся привертати до } \\
\text { себе увагу. }\end{array}$ & & & 2 & $\begin{array}{l}\text { тривожний(а). } \\
\text { 51. Я млію, у мене крутиться }\end{array}$ \\
\hline & $\mathbf{1}$ & 2 & 20. Я ламаю власні речі. & & & & голова. \\
\hline $\mathbf{0}$ & 1 & 2 & 21. Я ламаю речі, які належать іншим. & $\mathbf{0}$ & $\mathbf{1}$ & 2 & 52. Я занадто сильно відчуваю провину. \\
\hline $\mathbf{0}$ & 1 & 2 & 22. Я не слухаюся своїх батьків. & $\mathbf{0}$ & $\mathbf{1}$ & 2 & 53. Я їм занадто багато. \\
\hline $\mathbf{0}$ & $\mathbf{1}$ & 2 & 23. Я не слухаюся в школі. & $\mathbf{0}$ & 1 & 2 & 54. Я почуваюся перевтомленим без \\
\hline $\mathbf{0}$ & 1 & 2 & 24. Я не їм так добре, як мав би їсти. & & & & причини. \\
\hline $\mathbf{0}$ & $\mathbf{1}$ & 2 & 25. Я не лажу з іншими дітьми. & $\mathbf{0}$ & 1 & 2 & 55. У мене $\epsilon$ зайва вага. \\
\hline $\mathbf{0}$ & 1 & 2 & $\begin{array}{l}\text { 26. Я не почуваю провини за те, що } \\
\text { зробив щось, чого не мав би робити. }\end{array}$ & & & & $\begin{array}{l}\text { 56. У мене є Фізичні проблеми без відомої } \\
\text { медичної причини (діагнозу): }\end{array}$ \\
\hline $\mathbf{0}$ & $\mathbf{1}$ & 2 & 27. Я заздрю іншим. & $\mathbf{0}$ & 1 & 2 & а. Болі (не шлунковий та не головний біль). \\
\hline $\mathbf{0}$ & 1 & 2 & $\begin{array}{l}\text { 28. Я порушую правила вдома, в школі } \\
\text { чи в інших місцях. }\end{array}$ & & 1 & $\begin{array}{l}2 \\
2\end{array}$ & $\begin{array}{l}\text { b. Головний біль. } \\
\text { c. Нудота, нудить (тошнить). }\end{array}$ \\
\hline $\mathbf{0}$ & 1 & 2 & $\begin{array}{l}\text { 29. Я боюся певних тварин, ситуацій } \\
\text { або місць, окрім школи (опиши): }\end{array}$ & $\mathbf{0}$ & $\mathbf{1}$ & 2 & $\begin{array}{l}\text { d. Проблеми з очами (якщо не були } \\
\text { виправлені за допомогою окулярів) } \\
\text { (опиши): }\end{array}$ \\
\hline $\mathbf{0}$ & 1 & 2 & 30. Я боюся ходи & 0 & 1 & 2 & е. Висипання або інші проблеми зі шкірою \\
\hline $\mathbf{0}$ & $\mathbf{1}$ & 2 & $\begin{array}{l}\text { 31. Здається, в мене виникають погані } \\
\text { думки чи я роблю погані вчинки. }\end{array}$ & & & $\begin{array}{l}2 \\
2\end{array}$ & $\begin{array}{l}\text { f. Болі у животі. } \\
\text { g. Блювання. }\end{array}$ \\
\hline $\mathbf{0}$ & 1 & $\begin{array}{l}2 \\
2\end{array}$ & $\begin{array}{l}\text { 32. Я відчуваю, що мушу бути ідеальним. } \\
\text { 33. Я відчуваю, шо ніхто мене не любить. }\end{array}$ & $\mathbf{0}$ & 1 & 2 & h. Інше (опиши): \\
\hline
\end{tabular}


012 57. Я фізично нападаю на людей

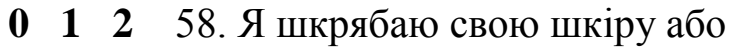
колупаюся в інших частинах тіла (опиши)

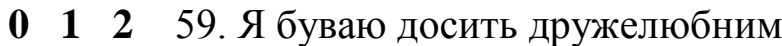

012 60. Мені подобається пробувати щось нове

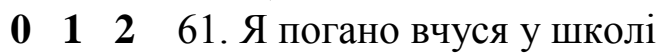

012 62. У мене погана координація або я незграбний

012 63. Я вважаю за краще бути з більш дорослими дітьми, ніж $з$ дітьми мого віку

012 64. Я вважаю за краще бути 3 молодшими дітьми, ніж 3 дітьми мого віку

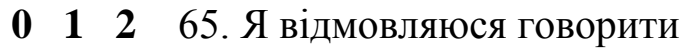

012 66. Я багаторазово повторюю певні дії (опиши)

012 67. Я можу тікати з дому

$\begin{array}{llll}\mathbf{0} & 1 & 2 & 68 . \text { Я багато кричу }\end{array}$

012 69. Я скритний або тримаю все в собі

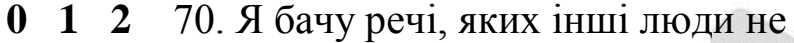
бачать (опиши)

012 71. Я занадто самосвідомий(а) або легко соромлюся

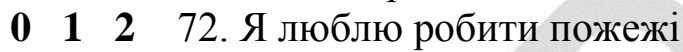
(підпалювати)

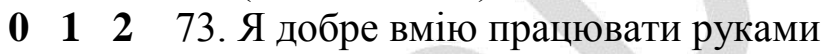

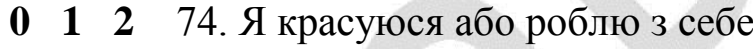
клоуна

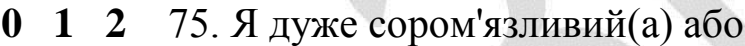
боязкий(a)

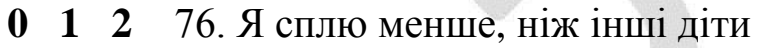

012 77. Я сплю більше, ніж інші діти продовж дня та/або ночі (опиши)

012 78. Я неуважний або легко відволікаюся

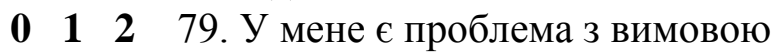
(опиши)

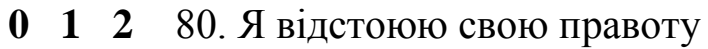

$\begin{array}{llll}0 & 1 & 2 & 81 . \text { Я краду з дому }\end{array}$

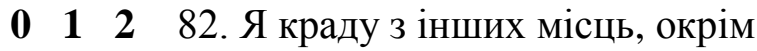
дому

012 83. Я зберігаю занадто багато непотрібних речей (опиши):

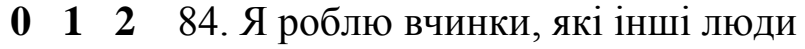

вважають дивними (опиши):

0 12 85. У мене є думки, які можуть іншим людям здатися дивними (опиши):

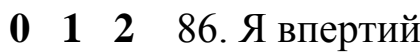

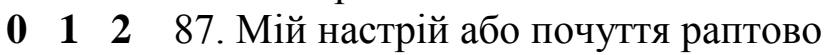
змінюються

012 88. Мені подобається бути серед людей

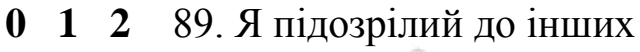

012 90. Я матюкаюся або використовую брудну мову

012 91. Я думаю про те, щоб заподіяти собі невідворотної шкоди

012 92. Мені подобається смішити інших

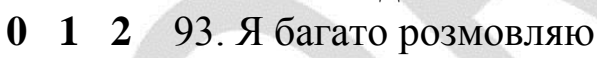

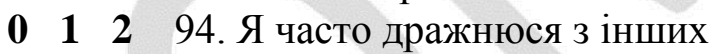

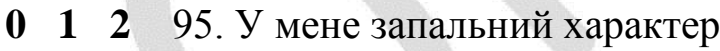

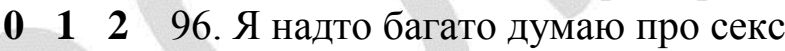

0 12 97. Я погрожую людям, що зроблю їм боляче

0 12 98. Я люблю допомагати іншим

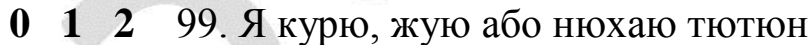

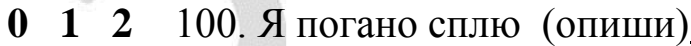

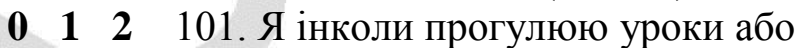
пропускаю школу без поважної причини

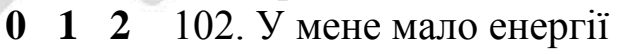

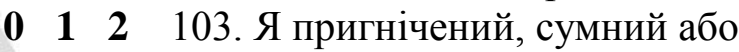
депресивний

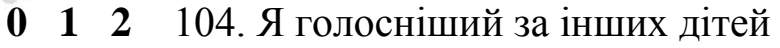

012 105. Я використовую наркотичні препарати для немедичних цілей (не згадуй тут алкоголь та тютюн) (опиши)

0 12 106. Мені подобається бути справедливим з іншими

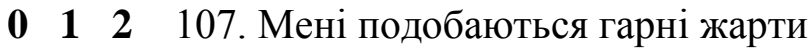

о 12 108. Мені подобається сприймати життя легко

012 109. Коли можу, я намагаюся допомагати іншим людям

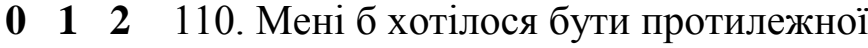
статі

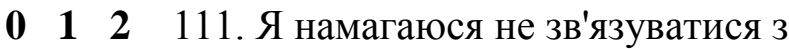
іншими

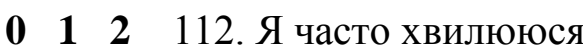


Ми намагаємось краще зрозуміти певні звички дітей і те чим вони займаються з друзями. Одне з таких занять - цее вжсиання алкоголю та інших наркотичних речовин.

Нам иүікаво наскільки цуе розповсюджено серед твоїх друзів.

Пам'ятай - ніхто (ні батьки, ні вчителі) про твої відповіді не дізнається!

Обведи або закресли номер обраної відповіді:

9. Чи с в тебе друзі, які палили цигарки (тютюн) у минулому році?

\begin{tabular}{l|c|c|c|c|c|} 
1. Так $\Rightarrow$ Якщо так, то скільки? & $\begin{array}{c}\text { Майже } \\
\text { нікого }\end{array}$ & Декілька & Половина & Більшість & $\begin{array}{c}\text { Майже } \\
\text { всі }\end{array}$ \\
\hline 2. Нi & 1 & 2 & 3 & 4 & 5 \\
\hline
\end{tabular}

10. Чи с в тебе друзі, які пили пиво, вино або будь-який напій, що містить алкоголь у минулому році?

1. Так $\Rightarrow$ Якщо так, то скільки?

2. $\mathrm{Hi}$

\begin{tabular}{|c|c|c|c|c|}
\hline $\begin{array}{c}\text { Майже } \\
\text { нікого }\end{array}$ & Декілька & Половина & Більшість & $\begin{array}{c}\text { Майже } \\
\text { всі }\end{array}$ \\
\hline 1 & 2 & 3 & 4 & 5 \\
\hline
\end{tabular}

11. Чи с в тебе друзі, які вживали (пробували) наркотичні речовини в минулому році?

1. Так $\Rightarrow$ Якщо так, то скільки?

2. Hi

\begin{tabular}{|c|c|c|c|c|}
\hline $\begin{array}{c}\text { Майже } \\
\text { нікого }\end{array}$ & Декілька & Половина & Більшість & $\begin{array}{c}\text { Майже } \\
\text { всі }\end{array}$ \\
\hline 1 & 2 & 3 & 4 & 5 \\
\hline
\end{tabular}

Дякуємо за те, щуо відповів на запитання про свойх друзів. Тепер ми хочемо задати декілька запитань про Тебе.

12. Чи палив ти колись цигарки (тютюн) в житті?

1. Так

2. $\mathrm{Hi}$
Якщо так, то ...

1. Скільки приблизно днів за останній рік? напиши цииррою кількість днів

2. Скільки днів впродовж останніх 30 днів?

(якщо такого не було, пиши «0») напиши циифрою кількість днів

13. Чи вживав ти колись більше, ніж кілька ковтків пива, вина або будь-якого напою, що містить алкоголь?

1. Так $\Rightarrow$ Якщо так, то ...

2. Hi

1. Скільки приблизно днів за останній рік? напиши циифрою кількість днів

2. Скільки днів впродовж останніх 30 днів?

(якщо такого не було, пиши «0») напиши циифрою кількість днів

14. Чи вживав ти колись (пробував) наркотичні речовини в житті?

1. Так $\Rightarrow$ Якщо так, то ... 1. Скільки приблизно днів за останній рік?

2. Hi напиши циифрою кількість днів

2. Скільки днів впродовж останніх 30 днів?

(якщо такого не було, пиши «0») напиши циифрою кількість днів 


\section{Опитувальник CRAFFT}

15. Пригадай, чи траплялися 3 тобою наступні речі?

Обведи або закресли номер обраної відповіді:

1 Ти коли-небудь їздив/ла у машині, за кермом якої була людина під впливом алкоголю чи наркотичних речовин?

2 Чи використовував/ла ти алкоголь чи наркотичні речовини, щоб розслабитися, або щоб відчувати себе кращою людиною чи краще вписатися в компанію?

3 Чи використовував/ла ти алкоголь чи наркотичні речовини без інших, на самоті?

4 Чи бувало таке, що ти не пам'ятаєш, що ти робив/ла, коли вживав/ла алкоголь чи наркотичні речовини?

5 Чи бувало таке, що хтось 3 рідних чи друзів тобі казав, що тобі треба зменшити (припинити) вживання алкоголю чи наркотичних речовин?

6 Чи виникали в тебе будь-які проблеми чи труднощі через те, що ти вживав/ла алкоголь чи наркотичні речовини?

\begin{tabular}{|c|c|c|} 
& Так & Ні \\
\hline & 1 & 2 \\
\hline або & 1 & 2 \\
\hline & 1 & 2 \\
\hline & 1 & 2 \\
\hline
\end{tabular}

\section{Опитувальник PBP - Peer Behavior Profile}

А тепер ми просимо тебе розповісти про своїх друзів:

\section{6. Скільки серед твоїх друзів тих, що ...}

Обведи або закресли номер обраної відповіді. Якщо тобі невідомо чи робили твої друзі описані речіобирай варіант «1 - Майже нікого».

\begin{tabular}{|c|c|c|c|c|c|c|}
\hline & & $\begin{array}{c}\text { Майже } \\
\text { нікого }\end{array}$ & Декілька & Половина & Більшість & $\begin{array}{c}\text { Майже } \\
\text { всі }\end{array}$ \\
\hline 1 & $\begin{array}{l}\text { Займаються додатковою навчальною діяльністю } \\
\text { (іноземна мова, математика, фізика ...) }\end{array}$ & 1 & 2 & 3 & 4 & 5 \\
\hline 2 & $\begin{array}{l}\text { Займаються в спортивних секціях (в тому числі } \\
\text { танцями) }\end{array}$ & 1 & 2 & 3 & 4 & 5 \\
\hline 3 & $\begin{array}{l}\text { Займаються у творчих або технічних гуртках } \\
\text { (шахи, театр, малювання ...) }\end{array}$ & 1 & 2 & 3 & 4 & 5 \\
\hline 4 & Займаються музикою & 1 & 2 & 3 & 4 & 5 \\
\hline 5 & Грають у комп’ютерні ігри & 1 & 2 & 3 & 4 & 5 \\
\hline 6 & «Зависають» / спілкуються у соціальних мережах & 1 & 2 & 3 & 4 & 5 \\
\hline 7 & Відмінники & 1 & 2 & 3 & 4 & 5 \\
\hline 8 & Прогулюють школу, тиняються & 1 & 2 & 3 & 4 & 5 \\
\hline 9 & $\begin{array}{l}\text { «Тусуються», збираються на вулиці, у дворі, у кафе } \\
\text { або в інших місцях задля спілкування }\end{array}$ & 1 & 2 & 3 & 4 & 5 \\
\hline 10 & $\begin{array}{l}\text { Займаються екстремальним спортом (скейтбоард, } \\
\text { ролики, велоспорт, ВМХ ...) }\end{array}$ & 1 & 2 & 3 & 4 & 5 \\
\hline 11 & Є частиною альтернативних груп (емо, готи ...) & 1 & 2 & 3 & 4 & 5 \\
\hline 12 & Однієї з тобою статі & 1 & 2 & 3 & 4 & 5 \\
\hline 13 & Були колись вигнані з уроків & 1 & 2 & 3 & 4 & 5 \\
\hline 14 & Часто викликають їх батьків до директора школи & 1 & 2 & 3 & 4 & 5 \\
\hline 15 & $\begin{array}{l}\text { Чинили вандалізм - псували, розмальовували, } \\
\text { розбивали, пошкоджували чиєсь майно }\end{array}$ & 1 & 2 & 3 & 4 & 5 \\
\hline 16 & Крали речі в інших людей & 1 & 2 & 3 & 4 & 5 \\
\hline 17 & Крали речі в магазині & 1 & 2 & 3 & 4 & 5 \\
\hline
\end{tabular}




\section{Опитувальник GSE}

17. Наскільки вірно наступні твердження описують тебе?

\begin{tabular}{|c|c|c|c|c|c|}
\hline & Обведи або закресли номер обраної відповіді: & $\begin{array}{c}\text { Зовсім } \\
\text { невірно }\end{array}$ & Трохи вірно & $\begin{array}{l}\text { У середньому } \\
\text { вірно }\end{array}$ & $\begin{array}{l}\text { Повністю } \\
\text { вірно }\end{array}$ \\
\hline 1 & $\begin{array}{l}\text { Я можу завжди впоратися з важкими } \\
\text { проблемами, якщо докладу достатньо } \\
\text { зусиль. }\end{array}$ & 1 & 2 & 3 & 4 \\
\hline 2 & $\begin{array}{l}\text { Якщо хтось встане в мене на перешкоді, я } \\
\text { знайду спосіб отримати що хочу. }\end{array}$ & 1 & 2 & 3 & 4 \\
\hline 3 & $\begin{array}{l}\text { Мені неважко бути наполегливим і досягати } \\
\text { поставленої мети і цілей. }\end{array}$ & 1 & 2 & 3 & 4 \\
\hline 4 & $\begin{array}{l}\text { Я переконаний, що можу ефективно } \\
\text { впоратися з непередбачуваними подіями. }\end{array}$ & 1 & 2 & 3 & 4 \\
\hline 5 & $\begin{array}{l}\text { Дякуючи своїй винахідливості, я знаю, як } \\
\text { справлятися з непередбачуваними } \\
\text { ситуаціями. }\end{array}$ & 1 & 2 & 3 & 4 \\
\hline 6 & $\begin{array}{l}\text { Я можу вирішити майже всі проблеми, якщо } \\
\text { докладу необхідних зусиль. }\end{array}$ & 1 & 2 & 3 & 4 \\
\hline 7 & $\begin{array}{l}\text { Я здатен зберігати спокій, зіштовхуючись із } \\
\text { труднощами, бо я можу покластися на свої } \\
\text { навички подолання труднощів. }\end{array}$ & 1 & 2 & 3 & 4 \\
\hline 8 & $\begin{array}{l}\text { Коли виникає проблема, як правило, я маю } \\
\text { кілька рішень. }\end{array}$ & 1 & 2 & 3 & 4 \\
\hline 9 & $\begin{array}{l}\text { Коли у мене труднощі, я, як правило, } \\
\text { знаходжу рішення. }\end{array}$ & 1 & 2 & 3 & 4 \\
\hline 10 & $\begin{array}{l}\text { Зазвичай я долаю все, що зі мною } \\
\text { трапляється. }\end{array}$ & 1 & 2 & 3 & 4 \\
\hline
\end{tabular}

\section{Опитувальник BFI-10}

18. Наскільки ти згодний(на) з наведеними нижче судженнями про тебе?

\begin{tabular}{|c|c|c|c|c|c|c|}
\hline & $\begin{array}{c}\text { Про мене можна сказати що я ... } \\
\text { Обведи або закресли номер обраної відповіді: }\end{array}$ & 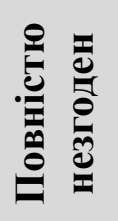 & 恶 & 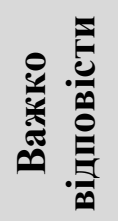 & 这 & 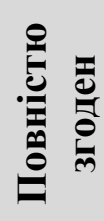 \\
\hline 1 & ... замкнутий & 1 & 2 & 3 & 4 & 5 \\
\hline 2 & ... зазвичай довіряю іншим & 1 & 2 & 3 & 4 & 5 \\
\hline 3 & ... дещо ледачий & 1 & 2 & 3 & 4 & 5 \\
\hline 4 & ... добре справляюся з напруженими ситуаціями & 1 & 2 & 3 & 4 & 5 \\
\hline 5 & ... схильний до занять творчістю & 1 & 2 & 3 & 4 & 5 \\
\hline 6 & $\begin{array}{l}\text {... без особливих зусиль знайомлюся і встановлюю } \\
\text { контакти з людьми }\end{array}$ & 1 & 2 & 3 & 4 & 5 \\
\hline 7 & ... легко помічаю недоліки інших людей & 1 & 2 & 3 & 4 & 5 \\
\hline 8 & ... роблю свою роботу ретельно і до кінця & 1 & 2 & 3 & 4 & 5 \\
\hline 9 & ... швидко починаю нервувати & 1 & 2 & 3 & 4 & 5 \\
\hline 10 & ... можу придумати щось нове & 1 & 2 & 3 & 4 & 5 \\
\hline
\end{tabular}




\section{Опитувальник AHP-SF}

19. Нижче наведені твердження стосуються твого способу життя або особистих звичок. Познач, будь ласка, якомога точніше, не пропускаючи відповіді, наскільки часто у тебе спостерігалась подібна поведінка протягом останніх 12 місяців ...

\begin{tabular}{|c|c|c|c|c|c|c|}
\hline & $\begin{array}{c}\text { Обведи або закресли номер обраної } \\
\text { відповіді: }\end{array}$ & $\begin{array}{c}\text { Ніколи } \\
\text { (до } 10 \%)\end{array}$ & $\begin{array}{l}\text { Рідко } \\
(30 \%)\end{array}$ & $\begin{array}{c}\text { У половині } \\
\text { випадків } \\
(50 \%) \\
\end{array}$ & $\begin{array}{l}\text { Часто } \\
(70 \%)\end{array}$ & $\begin{array}{c}\text { Постійно } \\
(90 \%+)\end{array}$ \\
\hline 1 & $\begin{array}{l}\text { 3дебільшого вибираю продукти з } \\
\text { низьким вмістом олії (жиру) }\end{array}$ & 1 & 2 & 3 & 4 & 5 \\
\hline 2 & $\begin{array}{l}\text { Ïм збагачену харчовими волокнами їжу } \\
\text { (фрукти і овочі) }\end{array}$ & 1 & 2 & 3 & 4 & 5 \\
\hline 3 & $\begin{array}{l}\text { Кожен мій прийом їжі включає } 5 \\
\text { харчових груп (наприклад, хліб, м'ясо, } \\
\text { молоко, фрукти, овочі) }\end{array}$ & 1 & 2 & 3 & 4 & 5 \\
\hline 4 & Дбаю про інших людей & 1 & 2 & 3 & 4 & 5 \\
\hline 5 & $\begin{array}{l}\text { Отримую задоволення від спілкування } 3 \\
\text { родичами }\end{array}$ & 1 & 2 & 3 & 4 & 5 \\
\hline 6 & Я обговорюю свої проблеми з іншими & 1 & 2 & 3 & 4 & 5 \\
\hline 7 & $\begin{array}{l}\text { Докладаю зусиль, щоб мати хороших } \\
\text { друзів }\end{array}$ & 1 & 2 & 3 & 4 & 5 \\
\hline 8 & $\begin{array}{l}\text { Читаю етикетки (склад), коли купую } \\
\text { продукти харчування }\end{array}$ & 1 & 2 & 3 & 4 & 5 \\
\hline 9 & Слідкую за своєю вагою & 1 & 2 & 3 & 4 & 5 \\
\hline 10 & $\begin{array}{l}\text { Обговорюю свій стан здоров'я } 3 \\
\text { медсестрою чи лікарем }\end{array}$ & 1 & 2 & 3 & 4 & 5 \\
\hline 11 & $\begin{array}{l}\text { Стежу за змінами свого тіла не рідше } \\
\text { одного разу на місяць }\end{array}$ & 1 & 2 & 3 & 4 & 5 \\
\hline 12 & Зазвичай думаю позитивно & 1 & 2 & 3 & 4 & 5 \\
\hline 13 & Намагаюся виправляти свої недоліки & 1 & 2 & 3 & 4 & 5 \\
\hline 14 & $\begin{array}{l}\text { Намагаюся дізнатися, що для мене } \\
\text { важливо }\end{array}$ & 1 & 2 & 3 & 4 & 5 \\
\hline 15 & $\begin{array}{l}\text { Намагаюся цікаво жити щодня, ставлю } \\
\text { собі складні завдання }\end{array}$ & 1 & 2 & 3 & 4 & 5 \\
\hline 16 & $\begin{array}{l}\text { Виконую інтенсивні фізичні вправи не } \\
\text { менше } 30 \text { хвилин принаймні } 3 \text { рази на } \\
\text { тиждень }\end{array}$ & 1 & 2 & 3 & 4 & 5 \\
\hline 17 & $\begin{array}{l}\text { Розминаюсь (розігріваюсь) перед } \\
\text { складними фізичними вправами }\end{array}$ & 1 & 2 & 3 & 4 & 5 \\
\hline 18 & Намагаюся стояти та сидіти прямо & 1 & 2 & 3 & 4 & 5 \\
\hline 19 & $\begin{array}{l}\text { Намагаюся визначити, звідки в мне } \\
\text { беруться стресові ситуації }\end{array}$ & 1 & 2 & 3 & 4 & 5 \\
\hline 20 & Складаю плани і визначаю пріоритети & 1 & 2 & 3 & 4 & 5 \\
\hline 21 & $\begin{array}{l}\text { Намагаюсь не втрачати контроль над } \\
\text { собою, коли відбуваються } \\
\text { несправедливі речі }\end{array}$ & 1 & 2 & 3 & 4 & 5 \\
\hline
\end{tabular}




\section{Опитувальник IBS}

20. Скільки разів ти робив/ла наступне в школі за останні 30 днів?

\begin{tabular}{|l|l|c|c|c|c|c|}
\hline \multicolumn{1}{|c|}{$\begin{array}{l}\text { Обведи або закресли номер обраної } \\
\text { відповіді: }\end{array}$} & Ніколи & $\mathbf{1 - 2}$ рази & $\mathbf{3 - 4}$ рази & $\mathbf{5 - 6}$ разів & $\begin{array}{c}\mathbf{7} \text { або } \\
\text { більше }\end{array}$ \\
\hline 1 & $\begin{array}{l}\text { Я засмучував інших учнів для власного } \\
\text { задоволення }\end{array}$ & 1 & 2 & 3 & 4 & 5 \\
\hline 2 & Я з групою друзів дражнив інших учнів & 1 & 2 & 3 & 4 & 5 \\
\hline 3 & Я поширював чутки про інших учнів & 1 & 2 & 3 & 4 & 5 \\
\hline 4 & $\begin{array}{l}\text { Я починав (підбурював) спори або } \\
\text { конфлікти }\end{array}$ & 1 & 2 & 3 & 4 & 5 \\
\hline 5 & $\begin{array}{l}\text { Я допомагав переслідувати / дратувати } \\
\text { інших учнів }\end{array}$ & 1 & 2 & 3 & 4 & 5 \\
\hline 6 & $\begin{array}{l}\text { Я погрожував вдарити або поранити } \\
\text { іншого учня }\end{array}$ & 1 & 2 & 3 & 4 & 5 \\
\hline 7 & Я підбурював інших до бійки & 1 & 2 & 3 & 4 & 5 \\
\hline 8 & Я сам дражнив інших учнів & 1 & 2 & 3 & 4 & 5 \\
\hline 9 & $\begin{array}{l}\text { Я робив підлості комусь, коли був } \\
\text { роздратований }\end{array}$ & 1 & 2 & 3 & & 5 \\
\hline
\end{tabular}

Скільки разів наступне траплялося 3 тобою в школі за останні 30 днів?

\begin{tabular}{|l|l|c|c|c|c|c|}
\hline \multicolumn{1}{|c|}{$\begin{array}{c}\text { Обведи або закресли номер обраної } \\
\text { відповід } i:\end{array}$} & Ніколи & $\mathbf{1 - 2}$ рази & $\mathbf{3 - 4}$ рази & $\mathbf{5 - 6}$ разів & $\begin{array}{c}\mathbf{7} \text { або } \\
\text { більше }\end{array}$ \\
\hline 10 & Інші учні чіплялись до мене & 1 & 2 & 3 & 4 & 5 \\
\hline 11 & Інші учні нецензурно лаяли мене & 1 & 2 & 3 & 4 & 5 \\
\hline 12 & $\begin{array}{l}\text { Інші учні давали мені принизливі } \\
\text { прізвиська }\end{array}$ & 1 & 2 & 3 & 4 & 5 \\
\hline 13 & Інші учні били та штовхали мене & 1 & 2 & 3 & 4 & 5 \\
\hline 14 & Інші учні погрожували мені & 1 & 2 & 3 & 4 & 5 \\
\hline 15 & $\begin{array}{l}\text { Інші учні поширювали чутки або } \\
\text { брехню про мене }\end{array}$ & 1 & 2 & 3 & 4 & 5 \\
\hline 16 & $\begin{array}{l}\text { Інші учні навмисно оминали мене або } \\
\text { виключали з друзів }\end{array}$ & 1 & 2 & 3 & 4 & 5 \\
\hline
\end{tabular}

\section{Опитувальник PSQ}

\section{1. Наступні питання стосуються твоїх звичок сну за останні 30 днів.}

Відповідай про типові дні (у більшості випадків).

\section{1. О котрій годині ти зазвичай лягав ввечері спати?}

Вкажи час відходу до сну:

\section{2. Як швидко (в хвилинах) зазвичай ти засинав щоночі?}

Приблизна кількість хвилин:

\section{3. Коли ти зазвичай прокидався вранці?}

Звичайний час підйому:

\section{4. Скільки годин ти реально спав вночі?}

(Це може відрізнятись від кількості годин, які ти проводив у ліжку)

Приблизна кількість годин сну за ніч: 
Наскільки часто з тобою відбувались наступні речі під час сну за останні 30 днів?

\begin{tabular}{|c|c|c|c|c|c|}
\hline & $\begin{array}{c}\text { Обведи або закресли номер обраної } \\
\text { відповіді: }\end{array}$ & $\begin{array}{c}\text { Жодного разу } \\
\text { протягом } \\
\text { минулого } \\
\text { місяця }\end{array}$ & $\begin{array}{c}\text { Менше } \\
\text { одного разу } \\
\text { на тиждень }\end{array}$ & $\begin{array}{c}\text { Один або два } \\
\text { рази на } \\
\text { тиждень }\end{array}$ & $\begin{array}{c}\text { Три або } \\
\text { більше разів } \\
\text { на тиждень }\end{array}$ \\
\hline 5 & Не міг заснути впродовж 30 хвилин & 1 & 2 & 3 & 4 \\
\hline 6 & Прокидався посеред ночі або дуже рано & 1 & 2 & 3 & 4 \\
\hline 7 & $\begin{array}{l}\text { Прокидався через потребу сходити до } \\
\text { туалету }\end{array}$ & 1 & 2 & 3 & 4 \\
\hline 8 & Було важко дихати & 1 & 2 & 3 & 4 \\
\hline 9 & Гучно кашляв або хропів & 1 & 2 & 3 & 4 \\
\hline 10 & Відчував, що було занадто холодно & 1 & 2 & 3 & 4 \\
\hline 11 & Відчував, що було занадто спекотно & 1 & 2 & 3 & 4 \\
\hline 12 & Снилися погані сни & 1 & 2 & 3 & 4 \\
\hline 13 & Турбував біль & 1 & 2 & 3 & 4 \\
\hline 14 & $\begin{array}{l}\text { Розмовляв чи ходив під час сну, а потім } \\
\text { не згадував про це }\end{array}$ & & & & \\
\hline 15 & Інші незручності (допиши щзо саме): & 1 & 2 & 3 & 4 \\
\hline 16 & $\begin{array}{l}\text { Як часто за останні } 30 \text { днів ти приймав } \\
\text { снодійні препарати? }\end{array}$ & 1 & 2 & 3 & 4 \\
\hline 17 & $\begin{array}{l}\text { Як часто за останні } 30 \text { днів ти } \\
\text { почувався сонним (невиспаним) } \\
\text { протягом дня? }\end{array}$ & 1 & 2 & 3 & 4 \\
\hline 18 & $\begin{array}{l}\text { Чи було за останні } 30 \text { днів достатньо у } \\
\text { тебе сил, щоб доводити все, що робиш, } \\
\text { до кінця? }\end{array}$ & 1 & 2 & 3 & 4 \\
\hline
\end{tabular}

За останні 30 днів, як би ти оцінив

19 якість Свого сну загалом? Обведи номер обраної відповіді:

\begin{tabular}{|c|c|c|c|} 
Дуже добре & $\begin{array}{c}\text { Скоріше } \\
\text { добре }\end{array}$ & $\begin{array}{c}\text { Скоріше } \\
\text { погано }\end{array}$ & Дуже погано \\
\hline 1 & 2 & 3 & 4 \\
\hline
\end{tabular}

\section{Опитувальник UCLA Loneliness Scale}

22. Будь ласка, вкажи як часто ти відчуваєш наступне ...

\begin{tabular}{|l|l|c|c|c|}
\hline & \multicolumn{1}{|c|}{ Обведи або закресли номер обраної відповід $i:$} & $\begin{array}{c}\text { Майже } \\
\text { ніколи }\end{array}$ & Інколи & Часто \\
\hline 1 & Як часто ти відчуваєш, що тобі бракує компанії? & 1 & 2 & 3 \\
\hline 2 & Як часто ти відчуваєш себе покинутим (ою)? & 1 & 2 & 3 \\
\hline 3 & Як часто ти відчуваєш себе ізольованим (ою) від інших? & 1 & 2 & 3 \\
\hline
\end{tabular}

\section{Опитувальник PHQ-4}

23. Як часто впродовж останніх 2 тижнів тебе турбували наступні речі?

\begin{tabular}{|l|l|c|c|c|c|}
\hline & \multicolumn{1}{|c|}{ Обведи або закресли номер обраної відповідi: } & $\begin{array}{c}\text { Жодного } \\
\text { разу }\end{array}$ & $\begin{array}{c}\text { Кілька } \\
\text { днів }\end{array}$ & $\begin{array}{c}\text { Більше } \\
\text { половини днів }\end{array}$ & $\begin{array}{c}\text { Майже } \\
\text { щодня }\end{array}$ \\
\hline 1 & $\begin{array}{l}\text { Дуже нервувався (лася), відчував (ла) надмірне } \\
\text { напруження, тривогу }\end{array}$ & 1 & 2 & 3 & 4 \\
\hline 2 & Був (ла) не в змозі припинити хвилювання & 1 & 2 & 3 & 4 \\
\hline 3 & $\begin{array}{l}\text { Зникло задоволення та інтерес до того, що раніше } \\
\text { було цікаво робити }\end{array}$ & 1 & 2 & 3 & 4 \\
\hline 4 & $\begin{array}{l}\text { Почувався пригніченим (ною), відчував (ла) } \\
\text { депресію, безнадійність }\end{array}$ & 1 & 2 & 3 & 4 \\
\hline
\end{tabular}




\section{Запитання NSDUH}

24. Пригадай, будь ласка, чи траплялось 3 тобою наступне ...

Обведи або закресли номер обраної відповіді:

1 Чи були у твоїх друзів коли-небудь думки про те, щоб покінчити життя самогубством?

2 Чи спілкувався ти 3 ким-небудь на теми, пов'язані 3 самогубством?

3 Чи пропонував тобі хто-небудь скоїти самогубство?

\begin{tabular}{|c|c|c|}
\hline Так & Нi & Не знаю \\
\hline 1 & 2 & 3 \\
\hline 1 & 2 & 3 \\
\hline
\end{tabular}

\section{Опитувальник ACSS-FAD}

25. Будь ласка, прочитай кожне твердження і вкажи, наскільки воно відображає тебе?

\begin{tabular}{|c|c|c|c|c|c|c|}
\hline & $\begin{array}{c}\text { Обведи або закресли номер обраної } \\
\text { відповідi: }\end{array}$ & $\begin{array}{l}\text { Зовсім не } \\
\text { про мене }\end{array}$ & \begin{tabular}{|c|} 
Скоріше не \\
про мене \\
\end{tabular} & \begin{tabular}{|c|} 
У чомусь так, \\
у чомусь ні \\
\end{tabular} & $\begin{array}{l}\text { Скоріше } \\
\text { про мене }\end{array}$ & $\begin{array}{l}\text { Повністю } \\
\text { про мене }\end{array}$ \\
\hline 1 & $\begin{array}{l}\text { Той факт, що я помру, на мене не } \\
\text { впливає. }\end{array}$ & 1 & 2 & 3 & 4 & 5 \\
\hline 2 & Мене лякає біль під час смерті. & 1 & 2 & 3 & 4 & 5 \\
\hline 3 & Я дуже боюся вмерти. & 1 & 2 & 3 & 4 & 5 \\
\hline 4 & $\begin{array}{l}\text { Я не нервуюся, коли люди говорять } \\
\text { про смерть. }\end{array}$ & 1 & 2 & 3 & 4 & 5 \\
\hline 5 & $\begin{array}{l}\text { Перспектива власної смерті викликає } \\
\text { в мене тривогу. }\end{array}$ & 1 & 2 & 3 & 4 & 5 \\
\hline 6 & $\begin{array}{l}\text { Мене не турбує смерть, як кінець } \\
\text { життя, у відомій мені формі. }\end{array}$ & 1 & 2 & 3 & 4 & 5 \\
\hline 7 & Я зовсім не боюся смерті. & 1 & 2 & 3 & 4 & 5 \\
\hline
\end{tabular}

\section{Опитувальник Food Security Scale}

26. Скільки разів за останні 30 днів ти вживав(ла) означені продукти?

\begin{tabular}{|l|l|c|c|c|c|c|}
\hline \multicolumn{1}{|c|}{$\begin{array}{c}\text { Продукти: } \\
\text { Обведи або закресли номер обраної відповід } i:\end{array}$} & $\begin{array}{c}\text { Кожен } \\
\text { день }\end{array}$ & $\begin{array}{c}\text { Два-три } \\
\text { рази на } \\
\text { тиждень }\end{array}$ & $\begin{array}{c}\text { Один раз } \\
\text { на } \\
\text { тиждень }\end{array}$ & $\begin{array}{c}\text { Один } \\
\text { раз на } \\
\text { місяць }\end{array}$ & $\begin{array}{c}\text { Не } \\
\text { вживав } \\
\text { (-ла) }\end{array}$ \\
\hline 1 & Цукерки & 1 & 2 & 3 & 4 & 5 \\
\hline 2 & Тістечка, здобні вироби & 1 & 2 & 3 & 4 & 5 \\
\hline 3 & М'ясо & 1 & 2 & 3 & 4 & 5 \\
\hline 4 & Варені ковбаси, сосиски, сардельки & 1 & 2 & 3 & 4 & 5 \\
\hline 5 & Копчені ковбаси & 1 & 2 & 3 & 4 & 5 \\
\hline 6 & Рибу & 1 & 2 & 3 & 4 & 5 \\
\hline 7 & Копчену рибу & 1 & 2 & 3 & 4 & 5 \\
\hline 8 & Молоко & 1 & 2 & 3 & 4 & 5 \\
\hline 9 & Сир & 1 & 2 & 3 & 4 & 5 \\
\hline 10 & Йогурт, кисломолочні продукти & 1 & 2 & 3 & 4 & 5 \\
\hline 11 & Морозиво & 1 & 2 & 3 & 4 & 5 \\
\hline 12 & Свіжі овочі & 1 & 2 & 3 & 4 & 5 \\
\hline 13 & Свіжі фрукти & 1 & 2 & 3 & 4 & 5 \\
\hline 14 & Майонез, соуси, кетчуп & 1 & 2 & 3 & 4 & 5 \\
\hline 15 & Фастфуд» & 1 & 2 & 3 & 4 & 5 \\
\hline 16 & Вуличну іжу (шаурму, хотдоги, пиріжки ...) & 1 & 2 & 3 & 4 & 5 \\
\hline 17 & Чіпси, сухарики & 1 & 2 & 3 & 4 & 5 \\
\hline 18 & Продукти швидкого приготування («мівіна») & 1 & 2 & 3 & 4 & 5 \\
\hline
\end{tabular}




\title{
Додаток 5. Рекомендація інструментарію ULS до практичного використання в закладах освіти
}

\author{
(4) \\ НАЦІОНАЛЬНА АКАДЕМТЯ ПЕДАГОГТЧІИХ НАУК УКРАЇНИ \\ ІНСТИТУТ ПСИХОЛОГІї ІМЕНІ Г. С. КОСТЮКА
}

01033, м. Кнїв. вул. Ганььківська. б. 2 Тел. 288-33-20. 288-19-63

\author{
30.08 .2021 № 20 \\ ВИТЯГ \\ 3 гротоколу № 10 засідання вченої ради \\ Іиституту психології імені Г.С. Коспюка НАПН України \\ від 30 серпия 2021 р.
}

СЛУХАЛИ: Про рекоменлацію до друку методичних рекомендацій «Украйнське

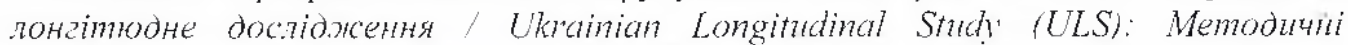
рекомендаиіі з використання психодіагностиних інструиентів другої хвилі доспідження / Максименко С. Д., Кокун О. М., Панок В. Г., Даниленко Г. М., Лінський 1. В., Сердюк О. О., Бурлака В. В., Шербакова О. О.».

\section{Penchзenil:}

Наталія ЧЕПЕЛСВА, заступник директора з науково-дослідпої робоги Інституту психологї імені Г.С. Костюка НАПН України, дійсний член НАПН України, доктор лсихологічних наук, ирофесор;

Олександр БОНДАРЕНКО, завідувач кафедри исихології і туризму Київського наиіінального лгінгвістичного університету, дійсний член НАГН Україци, доктор ıсихологічних наук, професор.

УХВАЛИЛИ: методичні рекомендації «Українське понімюдне досліджения / Ukrainian Longitudinal Study (ULS): Memoduthi peкonendauli 3 bukoplamants nсиходіадностичних інструнентів другої хвилі досліджения / Максименко С. Д., Кокун О.М., Ганок В.Г., Даниленко Г. М., Лінський І. В., СердюкО.О., Бурлака В. В., Щербакова О.О.» рекомендувати до друку та пгодальшого практинного використання в закладах освіти.

Рішення ухвалено одноголосно.

Директор

Вчений секретар

$$
\text { cforeny }
$$
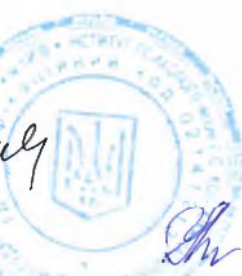

С.Д. Максименко

Г.В. Гуменок 


\title{
Додаток 6. Лист УНМЦ практичної психології і соціальної роботи від 12.05.2021 № 45
}

\author{
4 \\ НАЦПОНАЛЬНА АКАДЕМПЯ ПЕДАГОГЧНИХ НАУК УКРАЇНИ \\ УКРАЇНСЬКИЙ НАУКОВО-МЕТОДИЧНИЙ ЦЕНТР \\ ПРАКТИЧНОЇ ПСИХОЛОГІЇ І СОЦІАЛЬНОЇ РОБОТИ \\ юридична адреса: 01032, м. Київ, бульвар Т.Шевченка, 27-А \\ поштова адреса: 03045, м. Київ, пров. Віто-Литовський, б. 98-А \\ Тел/факс: (044) 252-70-11 e-mail: UCAP@ukr.net \\ № 45 від «12» травня $2021 \mathrm{p}$.

$\begin{array}{lr}\text { Директорам/завідувачам } & \text { обласних, } \\ \text { Київського м міського } & \text { навчально- } \\ \text { методичних } & \text { центрів/кабінетів } \\ \text { психологічної служби } & \end{array}$

Шановні колеги!

Інформуємо Вас про те, що досліднищьким консорціумом до якого входять Інститут психології імені Г. С. Костюка НАПН України, Український науковометодичний центр практичної психології і соціальної роботи НАПН України; Харківський національний університет внутрішніх справ, Державна установа «Інститут охорони здоров'я дітей та підлітків НАMН України»; Державна установа «Інститут неврології, психіатрії та наркології НАМН України», Школа соціальної роботи Університету Вейна та Центр залежностей Мічиганського університету (США) реалізується медико-соціальна досліднищька програма «Українське лонтітюдне дослідження».

Раніше нами було надіслано лист № 28 від 16 березня 2021 року, у якому ми пропонували пройти реєстрацію на серію вебінарів щодо цього дослідження. Зауважуємо на тому, що практичні психологи та соціальні педагоги, які не брали участі у вебінарі, але мають бажання, також можуть долучитись до цієї програми.

Метою програми $\epsilon$ моніторинг впливу різних факторів на здоров'я українських дітей протягом життя з особливим фокусом на ризикованій поведінці щодо власного здоров'я. Детальна інформація про дослідження, опис діагностичних інструментів, записи вебінарів «Українське лонгітюдне дослідження: інструкція для дослідників» та зразки супутніх документів можливо переглянути за покликанням: https://intellectfound.org/uk/project/uls

Просимо Вас сприяти участі працівників психологічної служби закладів загальної середньої освіти в цьому дослідженні.

Перед початком роботи працівникам психологічної служби необхідно познайомитись із інструкцією для дослідника, що додається.

Практичні психологи та соціальні педагоги, які зголосились взяти участь в Українському лонгітюдному дослідженні, мають погодити свої дії з директором 
З3СО та включити це дослідження до власного плану роботи на наступний навчальний рік.

Керівники 33СО, за бажанням, матимуть можливість укласти договір про співпрацю $з$ дослідницьким консорціумом.

За детальною інформацією щодо участі у медико-соціальній дослідницькій програмі «Українське лонгітюдне дослідження» необхідно звертатись до відповідальних виконавців - Щербакової Олени Олександрівни; тел. +380630372049, e-mail: lenascherbakova@ukr.net та Сердюка Олексія Олександровича; тел.+380503271771, e-mail: serdyuk.alexey@gmail.com.

Додаток: Інструкція 3 арк.

3 повагою,

Директор Центру

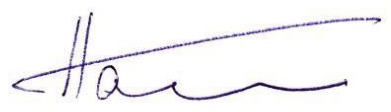

В.Г. Панок

252-70-11

Лунченко Н. В. 


\section{Додаток 7. Перелік нормативно-правових документів 3 питань запобігання та профілактики негативних форм поведінки серед дітей та молоді}

1. Указ Президента України від 25 травня 2020 року №195/2020 «Про Національну стратегію розбудови безпечного і здорового освітнього середовища у новій українській школі»

2. Указ Президента України від 21 вересня 2020 року №938/2020 «Про невідкладні заходи із запобігання та протидії домашньому насильству, насильству за ознакою статі, захисту прав осіб, які постраждали від такого насильства»

3. Указ Президента України від 24 березня 2021 року № 119/202 «Про Національну стратегію у сфері прав людини»

4. Указ Президента України від 30.09.2019 № 722/2019 «Про Цілі сталого розвитку України на період до 2030 року»

5. Постанова КМУ від 30 травня 2018 р. № 453 «Про затвердження Державної соціальної програми «Національний план дій щодо реалізації Конвенції ООН про права дитини» на період до 2021 року»;

6. Постанова КМУ від 01 червня 2020 р. № 585 «Про забезпечення соціального захисту дітей, які перебувають у складних життєвих обставинах»

7. Постанова КМУ від 1 червня 2020 р. № 587 «Про організацію надання соціальних послуг»

8. Постанова Кабінету Міністрів України № 658 від 22.08.2018 «Про затвердження Порядку взаємодії суб'єктів, що здійснюють заходи у сфері запобігання та протидії домашньому насильству і насильству за ознакою статі»

9. Постанова КМУ від 24 лютого 2021 р. № 145 «Питання Державної соціальної програми запобігання та протидії домашньому насильству та насильству за ознакою статі на період до 2025 року»

10. Розпорядження Кабінету Міністрів України № 728-р від 10.10.2018 «Про схвалення Концепції Державної соціальної програми запобігання та протидії домашньому насильству та насильству за ознакою статі на період до 2023 року»

11. наказ Міністерства освіти і науки України № 509 від 22.05.2018 «Про затвердження Положення про психологічну службу у системі освіти України»

12. наказ $\mathrm{MOH}$ від 02.10 .2018 № 1047 «Про затвердження Методичних рекомендації щодо виявлення, реагування на випадки домашнього насильства i взаємодії педагогічних працівників із іншими органами та службами»

13. наказ Міністерства освіти і науки України № 1646 від 28 грудня 2019 року «Деякі питання реагування на випадки булінгу (цькування) та застосування заходів виховного впливу в закладах освіти», зареєстрований в Міністерстві юстиції України 03 лютого 2020 р. за № 111/34394

14. наказ Міністерства освіти і науки від 26.02.2020 № 293 «Про затвердження плану заходів, спрямованих на запобігання та протидію булінгу (цькуванню) в закладах освіти»

15. лист Міністерства освіти і науки України від 29.01.2019 року за № $1 / 11$ - 881 «Рекомендації для закладів освіти щодо застосувань норм Закону України щодо протидії булінгу»

16. лист Міністерства освіти і науки України від 20.03.2020 року № 6/480-20 «Про план заходів, спрямованих на запобігання та протидію булінгу (цькуванню) в закладах освіти»

17. лист Міністерства освіти і науки України від 19.05.2020 № 6/645-20 «Щодо діяльності Національної дитячої гарячої лінії»

18. лист Міністерства освіти і науки України від 13.01.2020 № 6/37-20 «Про підвищення рівня педагогічної компетенції щодо запобігання та протидії проявам насильства в закладах освіти» 
19. лист Міністерства освіти і науки України від 11.02.2020 № 1/9-80 «Про затвердження наказу Міністерства освіти і науки України від 28 грудня 2019 року №1646 «Деякі питання реагування на випадки булінгу, (цькування) та застосування заходів виховного впливу в закладах освіти»

20. лист Міністерства освіти і науки України від 31.03.2020 № 063/3996 «Про план заходів спрямованих на запобігання та протидію булінгу (цькуванню) в закладах освіти»

21. лист Міністерства освіти і науки України від 16.04.2020 № 063/4673 «Роз'яснення щодо застосування наказу Міністерства освіти і науки України від 28.12.2019 №1646»

22. лист Міністерства освіти і науки України від 14.08.2020 №1/9-436 «Про створення безпечного освітнього середовища в закладі освіти та попередження і протидії булінгу (цькуванню)»

23. лист Міністерства освіти і науки України від 07.08.2018 № 1/9-486 «Про деякі питання організації в закладах освіти виховної роботи щодо безпеки і благополуччя дитини у 2018/2019 навчальному році»

24. лист Міністерства освіти і науки України від 29.12.2018 № 1/9-790 щодо організації роботи у закладах освіти з питань запобігання і протидії домашньому насильству та булінгу

25. лист Міністерства освіти і науки від 10.09.2019 № 1/9-570 щодо проведення в закладах освіти Всеукраїнського тижня з протидії булінгу

26. лист МОН від 20.03.2020 № 6/480-20 «Про план заходів, спрямованих на запобігання та протидію булінгу (цькуванню) в закладах освіти»

27. лист МОН від 27.06.19 № 1/9-414 «Деякі питання щодо створення у 2019/2020 н. р. безпечного освітнього середовища, формування в дітей та учнівської молоді ціннісних життєвих навичок»

28. лист Міністерства освіти і науки України від 17.11.2020 №6/1379-20 «Щодо Європейського дня захисту дітей від сексуальної експлуатації i сексуального насильства та Всеукраїнської акції «16 днів проти насильства»»»

29. лист МОН від 10 березня 2021 р. № 1/9-128 «Щодо необхідності проведення додаткових профілактичних заходів в середовищі дітей та підвищення обізнаності батьків» 
Українське Лонгітюдне Дослідження = Ukrainian Longitudinal Study (ULS) : Метод. рек. 3 У45 використання психодіагност. інструментів другої хвилі дослідж. / [Максименко С. Д., Кокун О. М., Панок В. Г., Даниленко Г. М., Лінський І. В., Сердюк О. О., Бурлака В. В., Щербакова О. О., Лунченко Н. В.] ; НАПН України, Ін-т психології ім. Г. С. Костюка, УНМЦ практичної психології та соціальної роботи ; НАМН України, ДУ Ін-т охорони здоров'я дітей та підлітків, ДУ Ін-т неврології психіатрії та наркології ; МВС України, Харків. нац. ун-т. внутр. Справ ; Ун-т Вейна. - Київ: Ін-т психології імені Г. С. Костюка НАПН України, 2021. - 72 с.

Методичні рекомендації 3 використання комплексу адаптованих для України міжнародних стандартизованих інструментів психодіагностики девіантної поведінки, скринінгу психічних та поведінкових розладів, депресії та тривожності, самотності та соціальної ізоляції, вживання психоактивних речовин, суїцидальних проявів, рівня булінгу, батьківської поведінки, сімейної гнучкості та згуртованості тощо. Висвітлено методику, методологію та інструментарій для науково-дослідної роботи в рамках Українського лонгітюдного дослідження (ULS). Значна увага приділяється інтерпретації результатів психодіагностики девіантної поведінки. Рекомендації містять інструкцію 3 проведення дослідження, зразки супутніх документів, рекомендацію інструментарію до використання в практичній роботі, офіційні листи МОН та психологічної служби.

Рекомендовано для працівників закладів освіти, психологів, медиків, соціологів і всіх, кого цікавлять питання дослідження соматичного та психічного розвитку дитини.

УДК 159.9.072:316.624

Наукове видання

МАКСИМЕНКО Сергій Дмитрович

КОКУН Олег Матвійович

ПАНОК Віталій Григорович

та ін.

\title{
Українське лонгітюдне дослідження Ukrainian Longitudinal Study (ULS)
}

\author{
Методичні рекомендації \\ з використання психодіагностичних інструментів \\ другої хвилі дослідження
}

Підпис. до друку 10.09.2019. Формат 60×84/18. Ум. друк. арк. 14,93.

Обл.-вид. арк. 8,52. Тир. 400 пр. Зам. № 2021-20.

Видавець і виготовлювач -

Інститут психології імені Г. С. Костюка НАПН України, Україна, вул. Паньківська 2, м. Київ, 01033

Свідоцтво суб’ єкта видавничої справи ДК № 3087 від 22.01.2008. 